\title{
Synthetic methods of cyclic $\alpha$-aminophosphonic acids and their esters
}

\author{
Tarik E. Ali \\ Department of Chemistry, Faculty of Education, Ain Shams University, Roxy, Cairo, Egypt \\ E-mail: tarik_elsayed1975@yahoo.com
}

DOI: $\underline{\text { http://dx.doi.org/10.3998/ark.5550190.p008.189 }}$

\begin{abstract}
This review describes the most synthetic methods of cyclic $\alpha$-aminophosphonic acids and their mono- or di-esters in which at least two atoms of the $\mathrm{P}-\mathrm{C}-\mathrm{N}$ system such as linkage of types $\mathrm{C}-\mathrm{P}, \mathrm{C}-\mathrm{N}$ and $\mathrm{P}-\mathrm{C}-\mathrm{N}$ are part of a heterocyclic system.
\end{abstract}

Keywords: Cyclic $\alpha$-aminophosphonic acids, Kabachnik-Fields, Pudovik reactions

\section{Table of Contents}

1. Introduction

2. Type A: Cyclic $\alpha$-Aminophosphonic Acid Derivatives Bearing an Exocyclic Amino Group (Heterocycles containing the phosphorus as a ring heteroatom)

2.1. Curtius rearrangement strategy on phosphorus heterocycles

2.2. Addition of dialkyl phosphite to $\mathrm{C}=\mathrm{C}$ (Pudovik reaction)

2.3. Multicomponent reaction (Kabachnik-Fields reaction)

3. Type B: Cyclic $\alpha$-Aminophosphonic Acid Derivatives Bearing an Exocyclic Phosphonyl Group (Heterocycles containing the nitrogen as a ring heteroatom)

3.1. Addition of dialkyl/trialkyl phosphite to cyclic imines (Pudovik reaction)

3.2. Addition of dialkyl phosphite to nitrones

3.3. Nucleophilic phosphonylation

3.4. Multicomponent reaction (Kabachnik-Fields reaction)

3.5. Diels-Alder reaction

3.6. Ring closure of iminophosphonates

3.7. Ring closure of oximinophosphonates

3.8. Ring closure of acyclic $\alpha$-aminophosphonates

3.9. Ring closure of acyclic $\beta$-aminophosphonates

3.10. Ring closure of acyclic $\gamma$-aminophosphonates 
3.11. Ring closure of acyclic $\delta$-aminophosphonates

3.12. Ring closure of acyclic $\alpha$-hydroxyphosphonates

3.13. Ring closure of isothiocyanatomethylphosphonates

3.14. Miscellaneous

3.14.1. Photocyclization

3.14.2. Reaction of azirine phosphonate with Grignard reagent

3.14.3. Phosphonylation of lactams

3.14.4. Hydrolysis of an acetal

3.14.5. Cycloaddition to phosphorylated nitrile ylide

3.14.6. Cycloaddition to phosphorylated nitrone

4. Type C: Cyclic $\alpha$-Aminophosphonic Acid Derivatives Containing the Phosphorus and

Nitrogen as Ring Heteroatoms

4.1. Addition of phosphorus reagents to acyclic imines

4.1.1. Addition of phosphites to cyclic imines (Pudovik reaction)

4.1.2. Addition of isocyanatophosphite to acyclic imines

4.2. Multicomponent reactions

4.2.1. Reaction of carbonyl and aminoalcohols with phosphites (Kabachnik-Fields reaction)

4.2.2. Reaction of cyclopropanone acetal and 1,2-aminohydroxyl compounds with phosphites

4.3. Ring closure of acyclic $\alpha$-aminophosphonates

4.4. Miscellaneous

4.4.1. Reaction of dialkyl/diphenyl phosphite with hydroxyl alkyl carbamate

4.4.2. Insertion of methyl phosphonate into oxazolidine moiety

5. Conclusions

References

\section{Introduction}

Organophosphorus compounds are important substrates in the study of biochemical processes ${ }^{1-4}$ and compounds of tetracoordinate pentavalent phosphorus are widely used as biologically active compounds. The key role of naturally occurring amino acids in the chemistry of life and as structural units in peptides, proteins, and enzymes has led to intense study on the chemistry and biological activity of synthetic analogues. For a long time the so-called "phosphorus analogues" of the amino acids, in which the carboxylic acid group is replaced by a phosphonic, $-\mathrm{P}(\mathrm{O})(\mathrm{OH})_{2}$, or phosphinic acid group, $-\mathrm{P}(\mathrm{O})(\mathrm{OH}) \mathrm{R}$ (in which $\mathrm{R}$ may be $\mathrm{H}$, alkyl, or aryl), as well as a phosphonate group, $-\mathrm{P}(\mathrm{O})(\mathrm{OR})_{2}$ (in which $\mathrm{R}$ may be alkyl, or aryl), have attracted particular interest in the preparation of isosteric or bioisosteric analogues of numerous natural products. ${ }^{5-8}$ In this area, $\alpha$-aminophosphonic acids, as isosteres of $\alpha$-amino acids (Figure 1) occupy an 
important place and reveal diverse and interesting biological and biochemical properties including antibacterial agents, ${ }^{9}$ enzyme inhibitors, ${ }^{10,11}$ haptens for catalytic antibodies, ${ }^{12}$ and anti HIV agents. ${ }^{13}$<smiles>[R]C(N)C(=O)O</smiles><smiles>[R]OP([R])(=O)C([R])N</smiles>

$$
\mathrm{R}^{1}=\mathrm{H} \text {, alkyl, aryl }
$$

\section{Figure 1}

Various synthetic methods for $\alpha$-aminophosphonic acids and $\alpha$-aminophosphonates have been reported ${ }^{14-22}$ and the most straightforward one is the addition of compounds containing a $\mathrm{P}-\mathrm{H}$ bond to the $\mathrm{C}=\mathrm{N}$ bond of imines (the Pudovik reaction) (Scheme 1) ${ }^{23}$ However, the most useful pathway to the synthesis of $\alpha$-aminophosphonates is the Kabachnik-Fields reaction, ${ }^{24-27}$ which is a one-pot, three-component procedure using carbonyl compound, amine and dialkyl phosphite (Scheme 2). This process was discovered at a time when multicomponent processes were rather "exotic birds"; from a modern point of view this protocol is obviously very attractive for combinatorial chemistry and has been rarely used for parallel synthesis. ${ }^{28}$<smiles>[R]NC([R])([R])P([R2])(=O)O[Z2]</smiles>

\section{Scheme 1}<smiles>[R]NC([R])([R])P([R20])(=O)O[Z20]</smiles>

\section{Scheme 2}

A few reviews have been published to date which are concerned with the synthesis, characterization, stereochemistry and biological activities of acyclic $\alpha$-aminophosphonate derivatives, ${ }^{29-31}$ but none of these focuses solely on the formation of cyclic $\alpha$-aminophosphonates. Therefore, this review will focus on the synthesis of cyclic $\alpha$-aminophosphonic acids and their mono- or $d i$-esters in which at least two atoms of the $\mathrm{P}-\mathrm{C}-\mathrm{N}$ system are part of a 
heterocyclic system. Thus, the heterocyclic systems which contain linkage of types $\mathrm{C}-\mathrm{P}$ (A), $\mathrm{C}-\mathrm{N}(\mathbf{B})$ and $\mathrm{P}-\mathrm{C}-\mathrm{N}(\mathbf{C})$ (Figure 2) are considered as cyclic $\alpha$-aminophosphonate derivatives. The review is built up according to the three previous linkage types and starting with the smallest rings in each type.

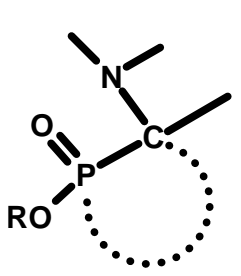

Type A

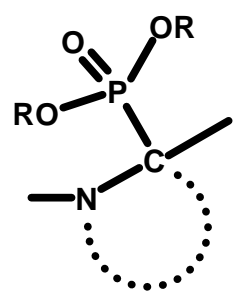

Type B

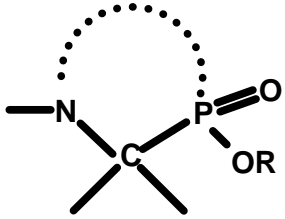

Type C

Figure 2

\section{Type A: Cyclic $\alpha$-Aminophosphonic Acid Derivatives Bearing an Exocyclic Amino Group (Heterocycles containing the phosphorus as a ring heteroatom)}

This type focuses on the synthesis of heterocyclic systems containing the $\alpha$-aminophosphonate moiety which contains the $\mathrm{P}-\mathrm{C}$ linkage as a part of the heterocyclic system (the phosphorus as a ring heteroatom).

\subsection{The Curtius rearrangement strategy on phosphorus heterocycles}

Ring closing metathesis (RCM) strategy was used in synthesis of the seven-membered P-heterocyclic $\alpha$-aminophosphonate 3 . Thus, monoallylation of tert-butyl diallylphosphonoacetate (1) using $\mathrm{NaH}$ and allyl bromide in THF at $0{ }^{\circ} \mathrm{C}$ followed by RCM utilizing the Grubbs benzylidene catalyst generated 1.2:1 mixtures of diastereomeric P-heterocycles $\mathbf{2}$ in excellent yield. On application of the Curtius rearrangement strategy to $\mathbf{2}$, Boc-protected $\alpha$-aminophosphonate $\mathbf{3}$ was generated in $48 \%$ overall yield as 1.5:1 mixture of separable diastereomers (Scheme 3). ${ }^{32}$

Subsequent allylation of an approximate of a 1:1 diastereomeric mixture of 2 produced 4 with 3:1 diastereoselectivity. RCM of the major diastereomer gave the [5,5,0]bicyclic tert-butylphosphoacetate $\mathbf{5}$ as the cis-fused diastereomer in excellent yield. This experiment also proved the stereoselectivity ( $c i s=$ major) in the allylation process of $\mathbf{2}$. Subjection of $\mathbf{5}$ to Curtius conditions gave the corresponding $\alpha$-Boc-bicyclic- $\alpha$-aminophosphonate 6 in $84 \%$ yield (Scheme 4). ${ }^{32}$ 


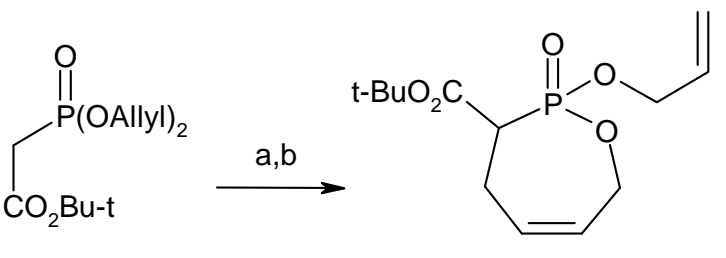

1

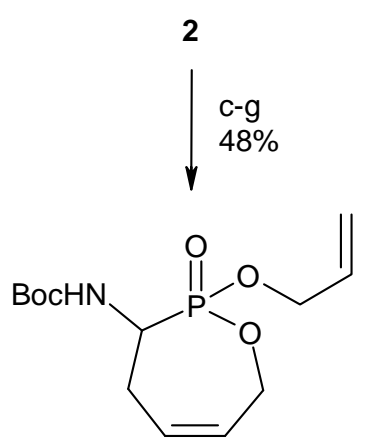

3

(a) $\mathrm{NaH}, \mathrm{THF}$, allyl bromide, $0{ }^{\circ} \mathrm{C}, 85 \% \quad$ (b) Grubbs catalyst (5\% mol) $\mathrm{CH}_{2} \mathrm{Cl}_{2}, 94 \%$

(c) Formic acid, neat (d) $(\mathrm{COCl})_{2}, \mathrm{CH}_{2} \mathrm{Cl}_{2}$, DMF, 0-rt ${ }^{\circ} \mathrm{C}$

(e) $\mathrm{NaN}_{3}, \mathrm{CH}_{3} \mathrm{CN}, \mathrm{H}_{2} \mathrm{O}$ quantitative (three steps) (f) toluene, reflux

(g) $\mathrm{t}-\mathrm{BuOH}$, reflux, $48 \%$

\section{Scheme 3}

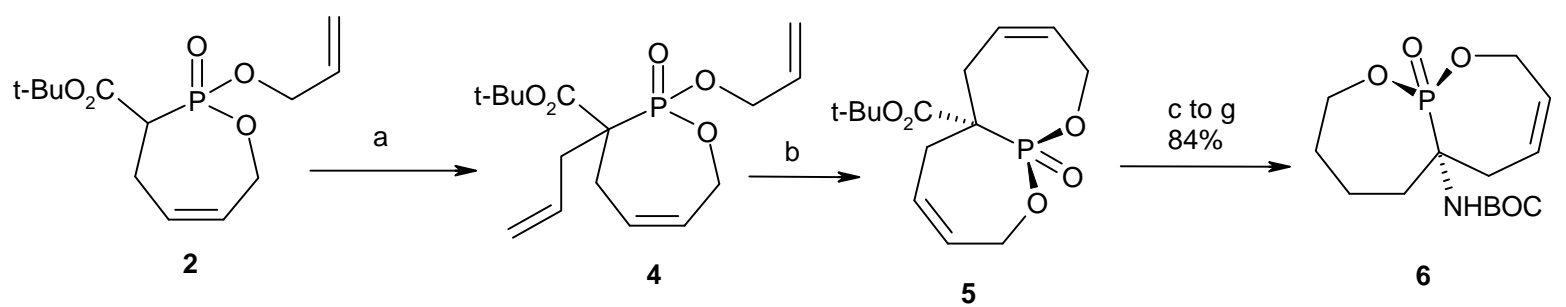
(a) KOBu-t, THF, allyl bromide, 0 -rt ${ }^{\circ} \mathrm{C}, 76 \%$ (b) Grubbs catalyst (5\% mol) $\mathrm{CH}_{2} \mathrm{Cl}_{2}, 97 \%$
(c) Formic acid, neat (d) $(\mathrm{COCl})_{2}, \mathrm{CH}_{2} \mathrm{Cl}_{2}$, DMF, 0-rt ${ }^{\circ} \mathrm{C}$
(e) $\mathrm{NaN}_{3}, \mathrm{CH}_{3} \mathrm{CN}, \mathrm{H}_{2} \mathrm{O}$ quantitative (three steps) (f) toluene, reflux
(g) $\mathrm{t}-\mathrm{BuOH}$, reflux, $84 \%$

\section{Scheme 4}

\subsection{Addition of dialkyl phosphite to double bond (The Pudovik reaction)}

Reaction of 3-(phenylaminomethylene)-2-hydroxy/ $\mathrm{N}$-phenylamino-6-methyl-2,3-dihydro-4Hchromen-4-ones (7) and (8) with diethyl phosphite at $90-100{ }^{\circ} \mathrm{C}$ afforded 3-phenylamino-2ethoxy-6-methyl-2-oxo-2,3,3a,9a-tetrahydro-4H-1,2-oxa-phospholo[5,4- $b$ ] chromen-4-one and 3-phenylamino-2-ethoxy-6-methyl-2-oxo-1-phenyl-2,3,3a,9a-tetrahydro-4H-1,2-azaphospholo[5,4-b]chromen-4-one (11), respectively, as cyclic $\alpha$-aminophosphonate derivatives. Formation of the compounds $\mathbf{1 0}$ and $\mathbf{1 1}$ may be interpreted as resulting from nucleophilic attack 
of the phosphorus atom at the $\alpha, \beta$-unsaturated moiety of 7 and $\mathbf{8}$ (Pudovik reaction) to give the nonisolable intermediate 9 . The latter underwent cyclization via elimination of one molecule of ethanol to give the final products $\mathbf{1 0}$ and 11, respectively (Scheme 5). ${ }^{33}$

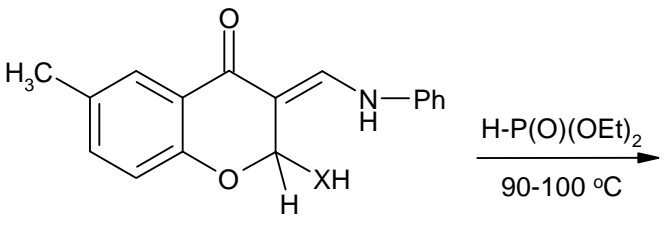

7, $\mathrm{X}=\mathrm{O}$

8, $\mathrm{X}=\mathrm{NPh}$

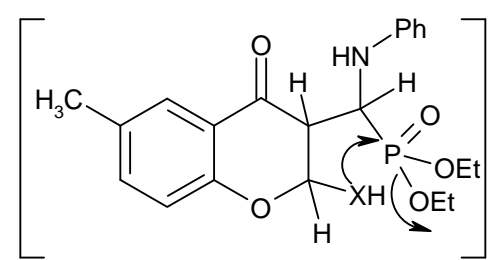

9 $-\mathrm{EtOH}$<smiles>[Y]C1C2(C)C(=O)c3cc(C)ccc3OC2([X])P1(=O)OCC</smiles>

$10, X=O$

11, $\mathrm{X}=\mathrm{NPh}$

\section{Scheme 5}

\subsection{Multicomponent (Kabachnik-Fields reaction)}

Aminophosphonylation of 4-benzyloxy-2-butanone (12) was performed with ammonia and diethyl phosphite under mild conditions. The $\alpha$-aminophosphonic ester 13 was obtained in $65 \%$ yield. Its debenzylation afforded diethyl 3-hydroxy-1-amino-1-methylpropylphosphonate 14 as a monohydrate. When a solution of the phosphonate 14 in 1,2-dimethoxyethane was treated with a catalytic amount of sodium hydride, 2-ethoxy-2-oxo-1,2-oxaphospholane 15 was obtained as a crude oil (Scheme 6). ${ }^{34}$ 

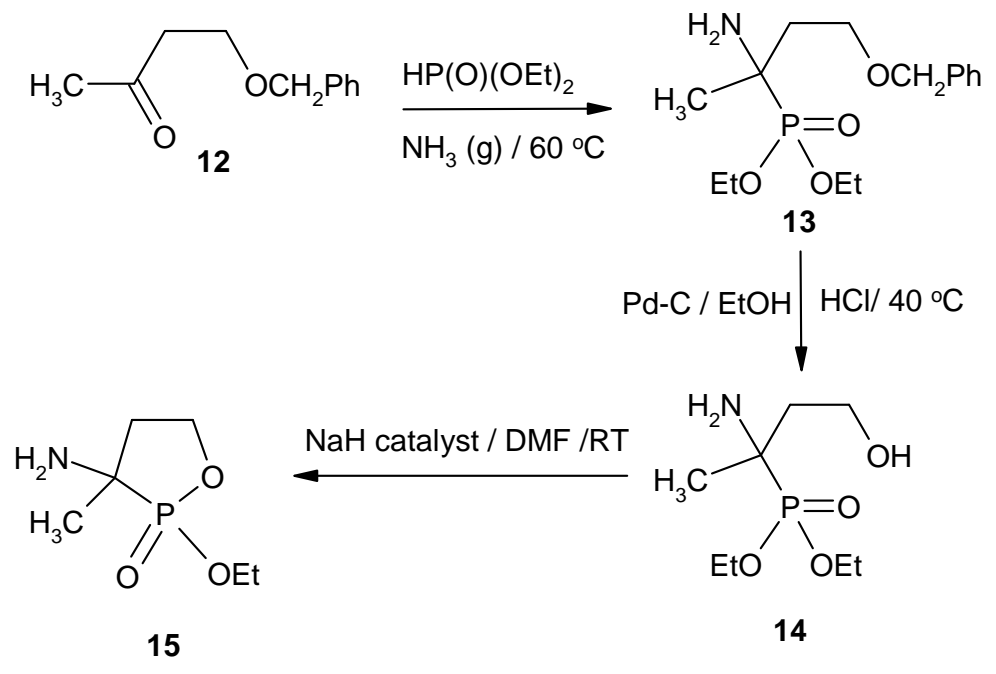

\section{Scheme 6}

The synthesis of the phosphorinane analogue $\mathbf{1 8}$ was performed by aminophosphonylation of the ketone 16 followed by base catalyzed cyclization. Diethyl 4-hydroxy-l-amino-1methylbutylphosphonate 17 was directly obtained in $45 \%$ yield by aminophosphonylation of 16, followed by treatment with a catalytic amount of sodium hydride in anhydrous 1,2-dimethoxyethane, at $60^{\circ} \mathrm{C}$ for 5 hours (Scheme 7). ${ }^{34}$

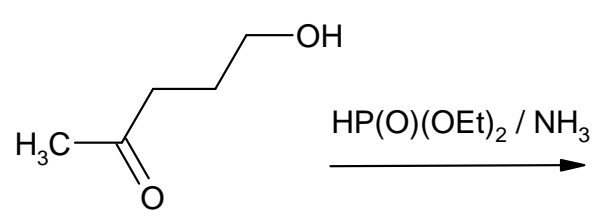

16

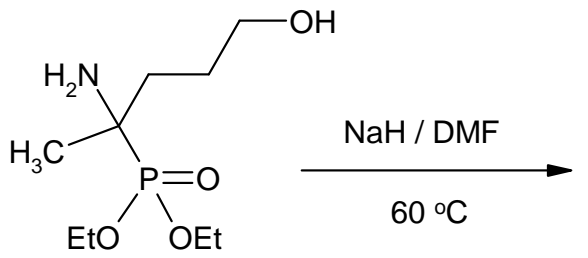

17

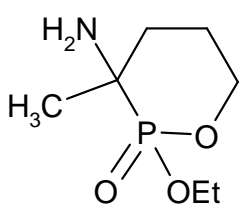

18

\section{Scheme 7}

\section{Type B: Cyclic $\alpha$-Aminophosphonic Acid Derivatives Bearing an Exocyclic Phosphonyl Group (Heterocycles containing the nitrogen as a ring heteroatom)}

This section focuses on the synthesis of heterocyclic systems containing the $\alpha$-aminophosphonate moiety which involves the $\mathrm{C}-\mathrm{N}$ linkage as a part of the heterocyclic system (the nitrogen as a ring heteroatom). 


\subsection{Addition of dialkyl/trialkyl phosphite to cyclic imines (Pudovik reaction)}

Nucleophilic addition of dialkyl phosphite to cyclic $\mathrm{C}=\mathrm{N}$ imines is one of the most direct ways to synthesize cyclic $\alpha$-aminophosphonates of this type. Addition of diisopropyl phosphite to the commercially available 2-methyl-1-pyrroline (19) produced diisopropyl $\alpha$-aminophosphonate 20 in $84 \%$ yield (Scheme 8$){ }^{35}$<smiles>CC1=NCCC1</smiles>

\section{Scheme 8}

The pyrrolidinyl phosphonic acid 25 can be formed in 50\% overall yield by chlorination of pyrrolidine 21 with $t$-butyl hypochlorite and subsequent elimination followed by reaction with diphenyl phosphite (Scheme 9). ${ }^{36,37}$

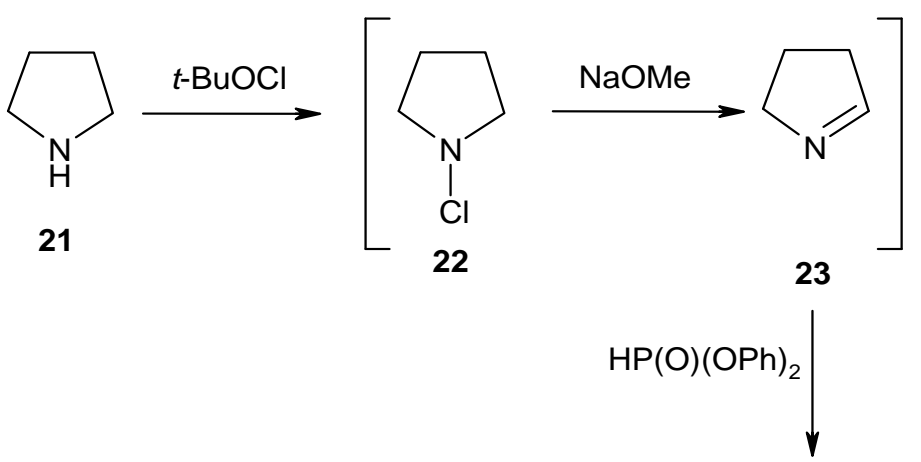

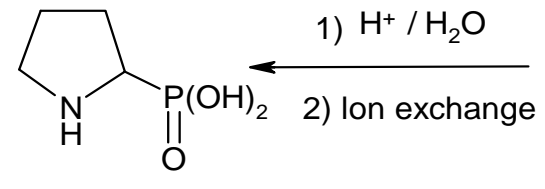

$25(50 \%)$

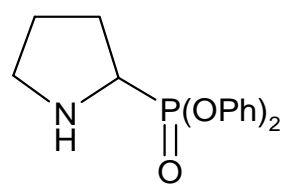

24

\section{Scheme 9}

The D-labelled pyrroline 27 was formed by an aza-Wittig reaction from azide $\mathbf{2 6}$. Addition of diethyl phosphite yielded the pyrrolidinephosphonic acid 28 in 97\% yeld (Scheme 10). ${ }^{38}$ 
<smiles>[2H]C([2H])([2H])C(=O)C([2H])([2H])CCNC1CCCC1c1ccccc1</smiles>

26<smiles>[2H]C([2H])([2H])C1=NCCC1([2H])[2H]</smiles>

27

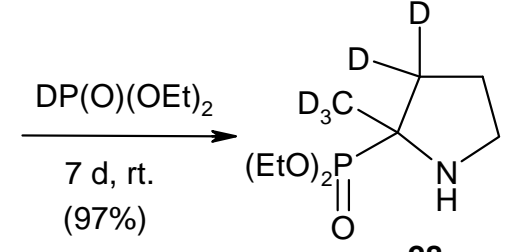

28

\section{Scheme 10}

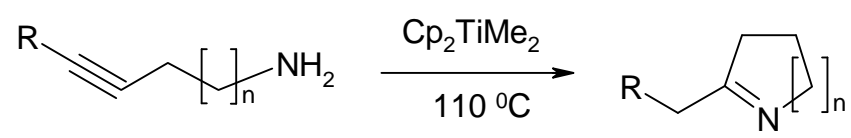

29

30

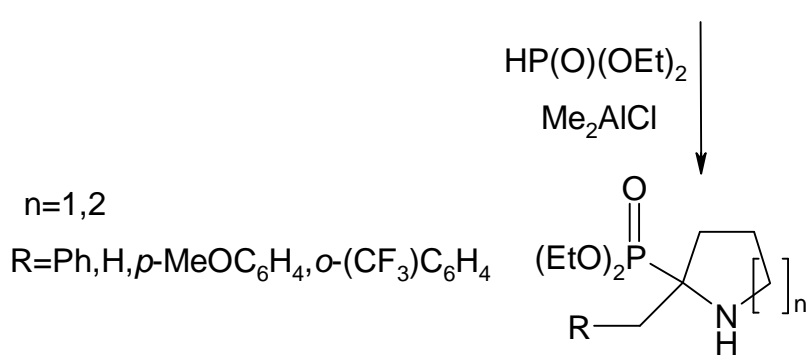

31 (58-86\%)

\section{Scheme 11}

In a one-pot synthesis of 2-phosphonopyrrolidines 31, the unsaturated 1-azaheterocycles 30 were formed by intramolecular hydroamination of aminoalkynes $\mathbf{2 9}$ in the presence of catalytic amounts of $\mathrm{Cp}_{2} \mathrm{TiMe}_{2}$ at $110{ }^{\circ} \mathrm{C}$ (Scheme 11). After addition of diethyl phosphite together with 5 mol \% $\mathrm{Me}_{2} \mathrm{AlCl}$, the phosphonylated pyrrolidines 31 were obtained in good overall yields (Scheme 11). ${ }^{39}$

Treatment of $N$-benzylproline (32) with oxalyl chloride followed by decarbonylation led to the formation of the iminium salt 34. 2-Phosphonopyrrolidine 25 was then obtained by addition of diethyl phosphite followed by debenzylation and dealkylation, in $90 \%$ overall yield (Scheme $12) .^{36}$ 


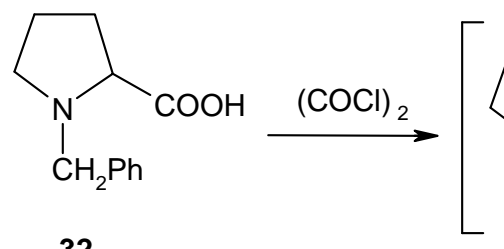

32

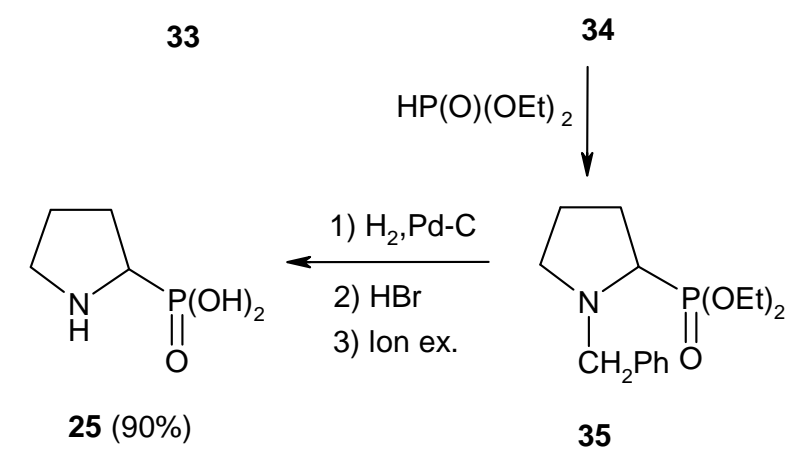

\section{Scheme 12}

Addition of diethyl phosphite to $\alpha$-substituted cyclic imines 36 gave cyclic $\alpha$-substituted $\alpha$-aminophosphonates 37. The reaction proceeded in ether or THF as a solvent at room temperature without any catalyst, but boron trifluoride etherate could be used to accelerate the reaction (Scheme 13). ${ }^{40}$

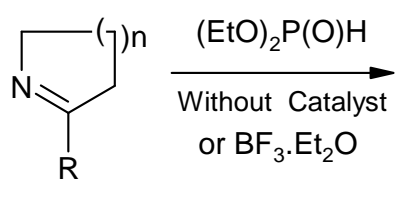

36

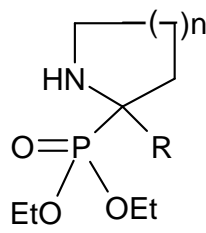

37

$\mathrm{n}=1,2,3$

$\mathrm{R}=\mathrm{Me}, i-\mathrm{Pr}, n-\mathrm{Bu}, \mathrm{Ph}, 4-\mathrm{MeC}_{6} \mathrm{H}_{4}$, 2-pyridyl, 2-thienyl

\section{Scheme 13}

Addition of diethyl phosphite to perfluoroalkyl substituted cyclic imines $\mathbf{3 8}$ does not proceed in the absence of catalyst. Under catalysis, $\alpha$-perfluoroalkyl substituted cyclic $\alpha$-aminophosphonates 39 were obtained in higher yields than their non-fluorinated analogues mentioned above. As steric hindrances decreases the reaction rate, the formation of five-membered aminophosphonates $39(\mathrm{n}=1)$ proceed faster comparing to those having a six-membered ring $(\mathrm{n}=2)$ and compound $\mathbf{3 9}$ bearing a trifluoromethyl group is formed more readily than those having the pentafluoroethyl moiety. In spite of the presence of strong electron withdrawing perfluorinated substituent, $\alpha$-aminophosphonates $39(\mathrm{n}=1,2)$ can be converted into the corresponding $\alpha$-aminophosphonic acids $\mathbf{4 0}$ via the reaction with trimethylbromosilane in 
chloroform followed by treatment with aqueous methanol of the intermediate trimethylsilyl ester formed (Scheme 14). ${ }^{40}$

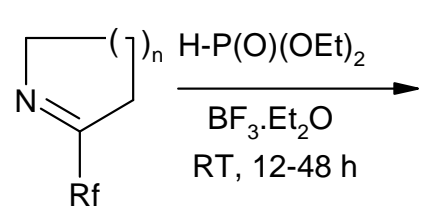

38

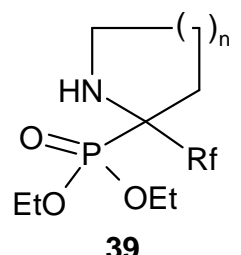

39

$\mathrm{Rf}=\mathrm{CF}_{3}, \mathrm{n}=1,2$

$\mathrm{Rf}=\mathrm{C}_{2} \mathrm{~F}_{5}, \mathrm{n}=1,2$

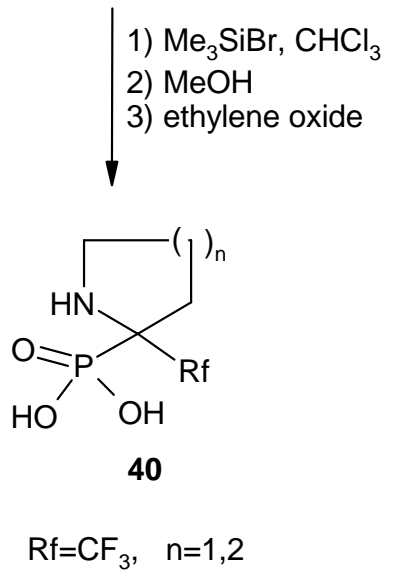

\section{Scheme 14}

In a similar way, enantioselective hydrophosphonylation of cyclic imines 41 using cyclic phosphites, catalyzed by $(S)$-YbPB (a yitterbium-binolate complex) provided the 4-thiazolidinyl phosphonates $(R)-\mathbf{4 2}$ in excellent enantiomeric excess and high chemical yields (Scheme 15). ${ }^{41}$

Since the chiral auxiliary might be easily removed by hydrolysis of the phosphonic ester, Schlemminger et al $^{42}$ carried out the addition of chiral BINOL-phosphite to achiral 3-thiazolines 41 in the presence of $\mathrm{BF}_{3}-\mathrm{OEt}_{2}$, obtaining the corresponding thiazolidinyl phosphonates 43 in moderate yield and excellent diastereoselectivity. It is noteworthy that the stereoselectivity of the BINOL-phosphite seemed to be independent of the steric demands of the nearby substituents $\mathrm{R}$ (Scheme 16). ${ }^{43}$ 


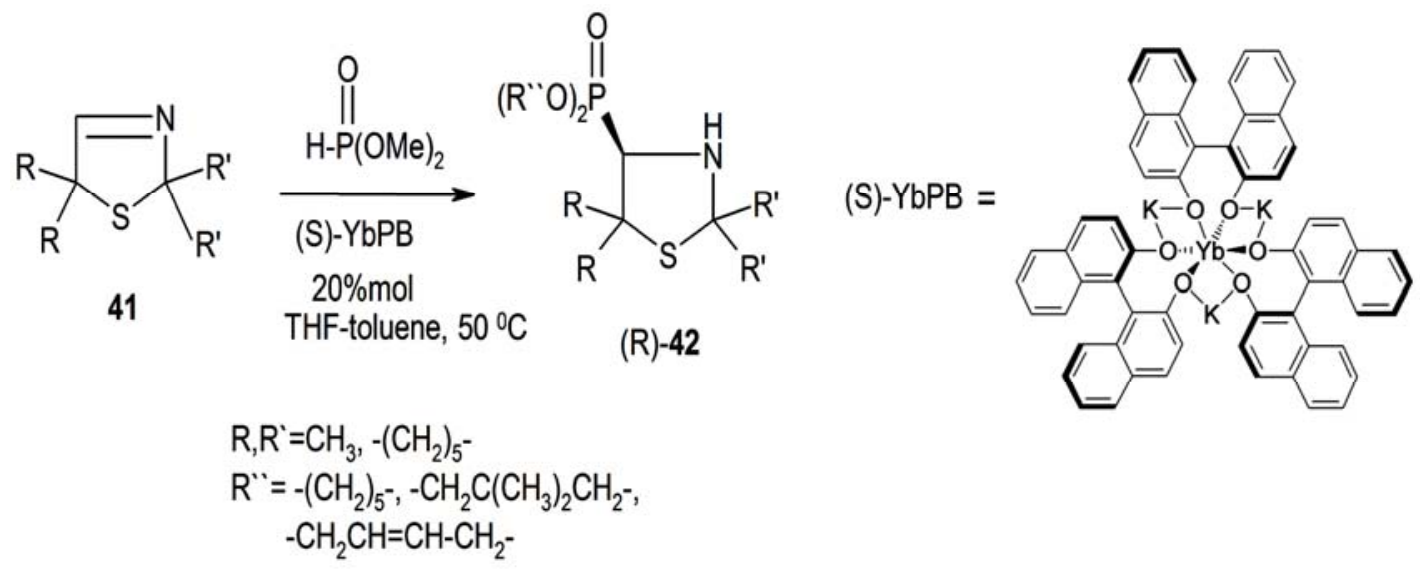

\section{Scheme 15}
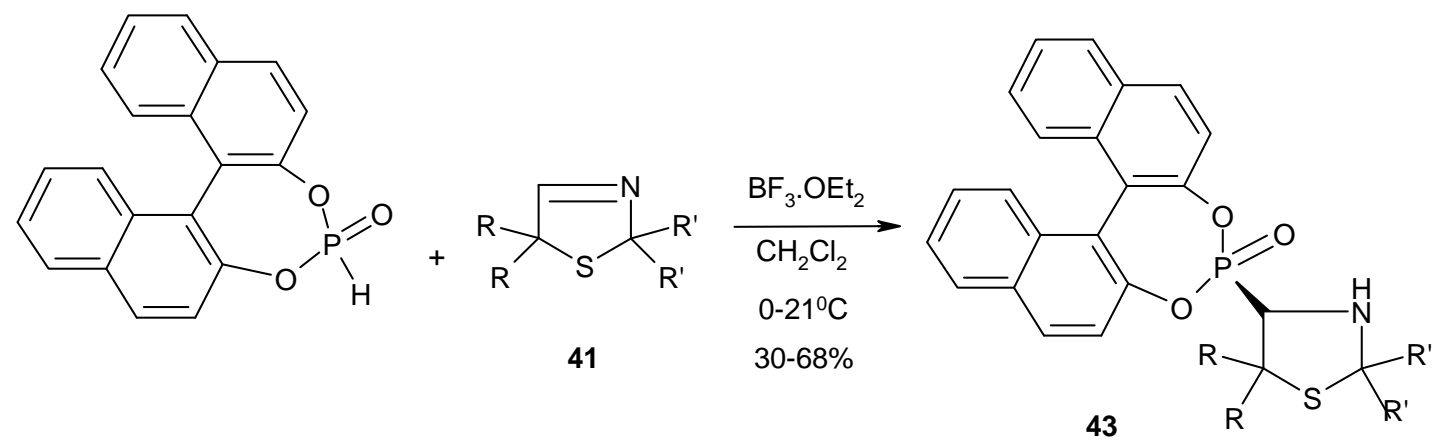

$\mathrm{R}=\mathrm{H}, \mathrm{CH}_{3},-\left(\mathrm{CH}_{2}\right)_{5}-$

$\mathrm{R}^{\prime}=\mathrm{CH}_{3},-\left(\mathrm{CH}_{2}\right)_{5}^{-}$

\section{Scheme 16}

3,4-Dihydroisoquinoline (44) added diethyl phosphite to yield the tetrahydroisoquinolyl phosphonate 45 (Scheme 17). ${ }^{44}$

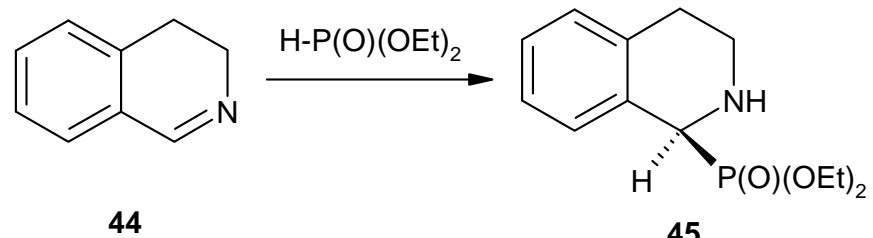

\section{Scheme 17}

Reaction of carbocyclic imines $\mathbf{4 6}$ with two equivalent of triethyl phosphite in the presence of one equivalent of TFA in ethanol at $300{ }^{\circ} \mathrm{C}$ for $17 \mathrm{~h}$ gave the corresponding $\alpha$-aminophosphonates 47 and 48 in ratios 89:11 to 99:1, respectively (Scheme 18). ${ }^{45}$ 
<smiles>[X]CC1OC(=O)C(Cc2ccccc2)N=C1CC</smiles>

46

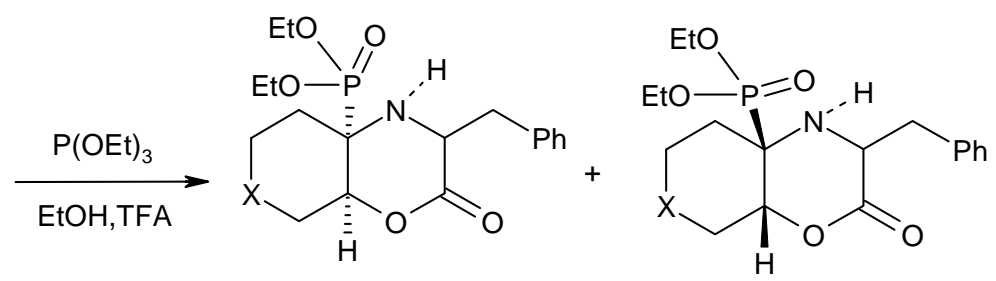

$47 \quad$ dr 88:11 to $99: 1 \quad 48$

\section{Scheme 18}

The synthesis of dialkyl 2-(1,1-dialkyl-5,5-dimethyl-1,3-thiazinan-4-yl)phosphonate (51) and 2,2-dimethyl-3,4-dihydro-2H-1,4-benzothiazine-3-dialkylphosphonate (52) was quite simple, requiring the reflux of a mixture of the cyclic imines 49 or 50, respectively, with dialkyl phosphite in ligroin for 18 hours (Scheme 19). ${ }^{46}$

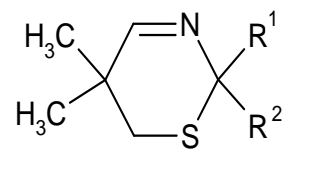

49

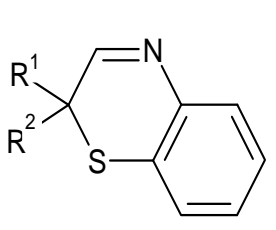

50

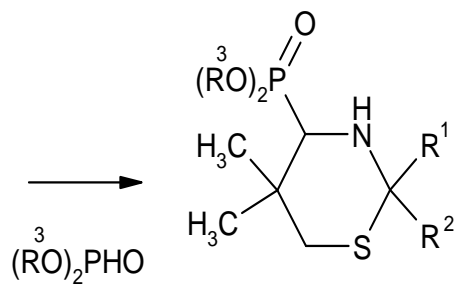

51

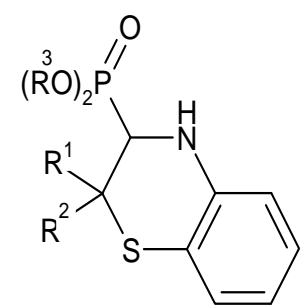

52

$$
\mathrm{R}^{1}=\mathrm{H}, \mathrm{CH}_{3}, \mathrm{R}^{2}=\mathrm{CH}_{3},-\left(\mathrm{CH}_{2}\right)_{4}^{-}, \mathrm{C}\left(\mathrm{CH}_{3}\right)_{3}, \mathrm{R}^{3}=\mathrm{CH}_{3}, \mathrm{CH}_{3} \mathrm{CH}_{2}
$$

\section{Scheme 19}

Quino[2,3-b][1,5]benzoxazepine $\alpha$-aminophosphonates 54 were obtained from the reaction of quino[2,3-b][1,5]benzoxazepines 53 with triethyl phosphite at room temperature under solvent-free conditions employing a catalyst such as $\mathrm{KAl}\left(\mathrm{SO}_{4}\right)_{2}, \mathrm{FeCl}_{3}, \mathrm{CaCl}_{2}, \mathrm{NiCl}_{2}$ and $p$-TSA (Scheme 20). ${ }^{47,48}$ 


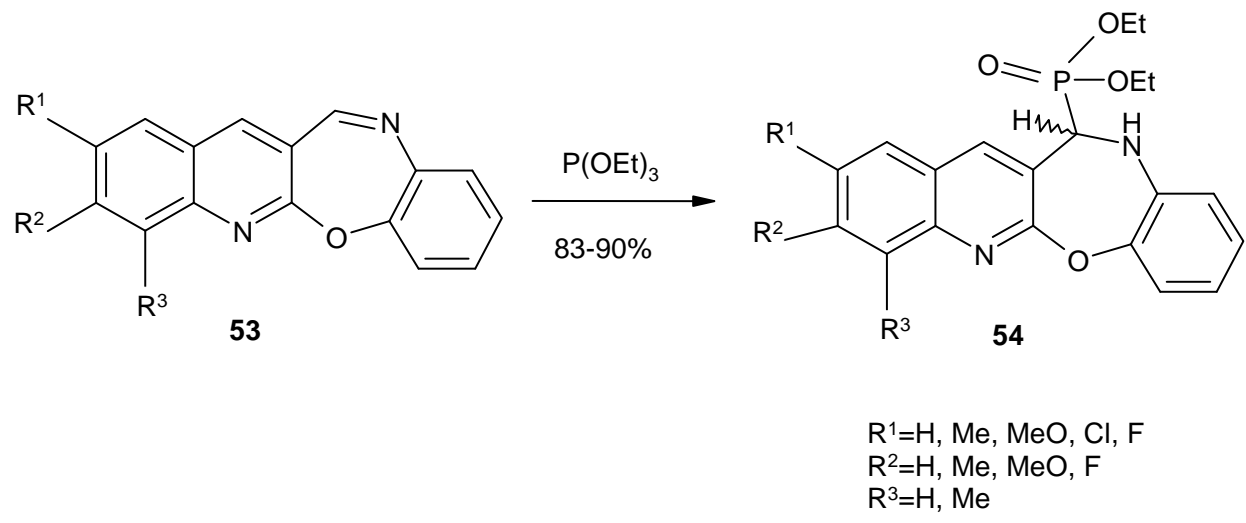

\section{Scheme 20}

Oxa-aza mixed macrocycles containing $\alpha$-aminophosphonate moieties 56 were synthesized by the reaction of diethyl phosphite and the 3,4:9,10-dibenzo-1,12-diaza-5,8-dioxacyclopentadecane (55) (Scheme 21). ${ }^{49}$

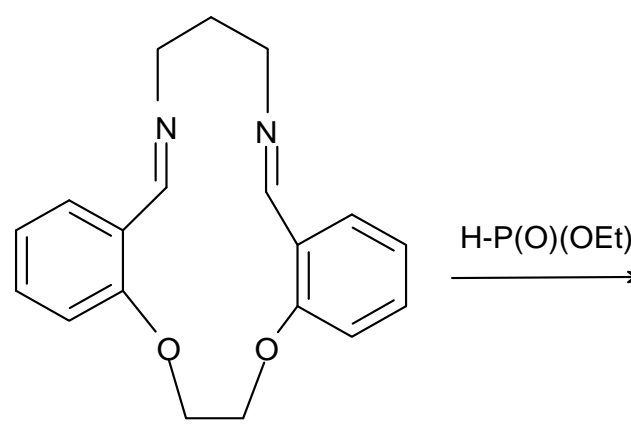

55

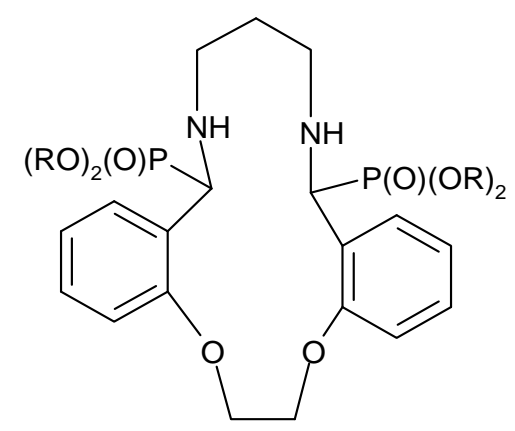

56

$\mathrm{R}=\mathrm{H}, 44 \%$

$\mathrm{R}=\mathrm{Et}, 73 \%$

\section{Scheme 21}

\subsection{Addition of dialkyl phosphite to nitrones}

Addition of dimethyl or diethyl phosphite to the nitrone 57 at $40{ }^{\circ} \mathrm{C}$ gave the corresponding $N$ hydroxyphosphonates 58a,b in quantitative yield. $O, N$-bis-deprotection of 58a,b by hydrogenolysis over $\mathrm{Pd} / \mathrm{C}$ in ethanol and aqueous hydrochloric acid afforded the pyrrolidinephosphonates $\mathbf{5 9 a}, \mathbf{b}$ as the hydrochlorides in $43 \%$ and $61 \%$ yield, respectively (Scheme 22$).{ }^{50}$

Alkylation of pyrroline $N$-oxides $\mathbf{6 0}$ with triethyloxonium tetrafluoroborate (Meerwein's salt) or benzyl iodide followed by reaction with diphenyl phosphite led to the formation of phosphonates 62a,b in $70 \%$ and $82 \%$ yield, respectively (Scheme 23 ). ${ }^{51}$

The treatment of nitrone $\mathbf{6 3}$ with sodium diisopropyl phosphite, gave a complex mixture of products, which were isolated as: starting material 63, imine 64 and diisopropyl amino- 
phosphonate 65. Compound 65 was also obtained from treatment of 64 with diisopropyl phosphite in the presence of sodium diisopropyl phosphite or DBU in THF (Scheme 24). ${ }^{52}$

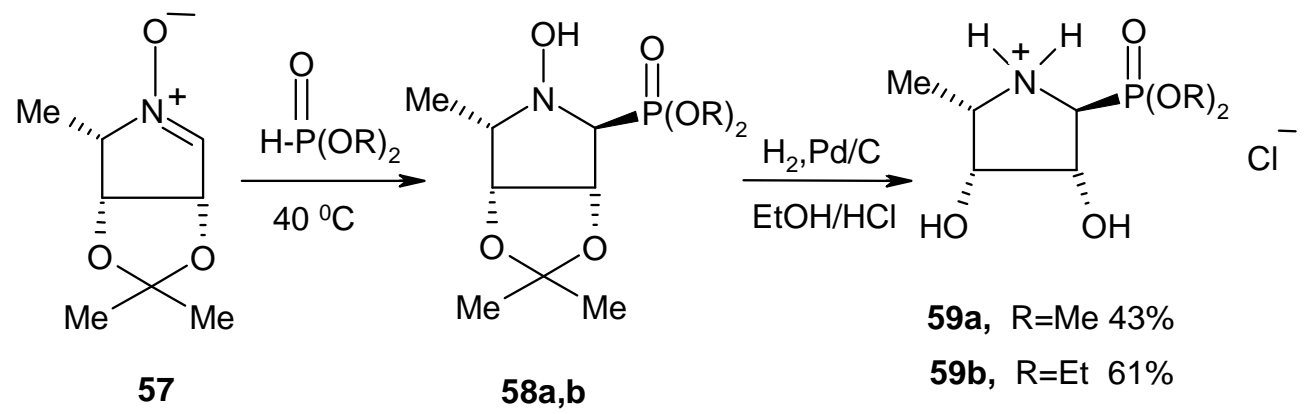

\section{Scheme 22}

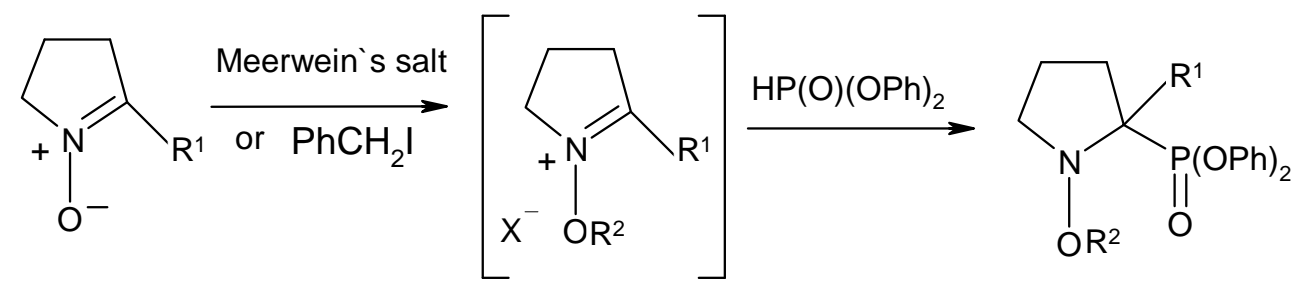

60

61

a $\mathrm{R}^{1}=\mathrm{H}, \mathrm{R}^{2}=\mathrm{Et}, \quad \mathrm{X}=\mathrm{BF}_{4}$

b R $\mathrm{R}^{1}=\mathrm{Me}, \mathrm{R}^{2}=\mathrm{PhCH}_{2}, \quad \mathrm{X}=\mathrm{I}$ 62a (70\%)

62b (82\%)

\section{Scheme 23}

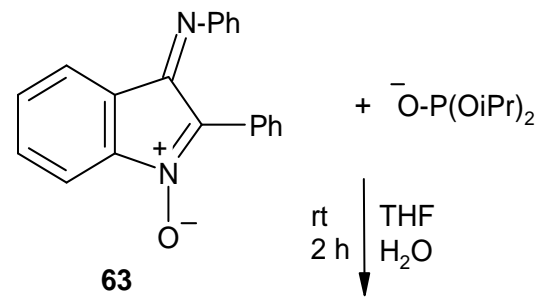<smiles>[O-][N+]1=C(c2ccccc2)/C(=N\c2ccccc2)c2ccccc21</smiles>

63

$32 \%$<smiles>[PH2+]c1cccc2ccccc2/c1=N/c1ccccc1</smiles>

64 $29 \%$<smiles>O[PbH](C(=Nc1ccccc1)c1ccccc1)c1ccccc1</smiles>

65

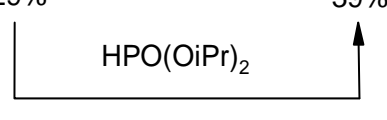

$\mathrm{NaPO}(\mathrm{OiPr})_{2}$ or DBU

\section{Scheme 24}


Ethylation of the nitrone $\mathbf{6 6}$ afforded the oxoiminium salt $\mathbf{6 7}$, which reacted with diphenyl phosphite to yield the corresponding $R$-methyl- $N$-alkoxyphosphonopiperidine $\mathbf{6 8}$ in $78 \%$ yield. Hydrogenolysis of the N-O bond furnished the phosphonopiperidine 69 in $82 \%$ yield (Scheme $25)^{51}$

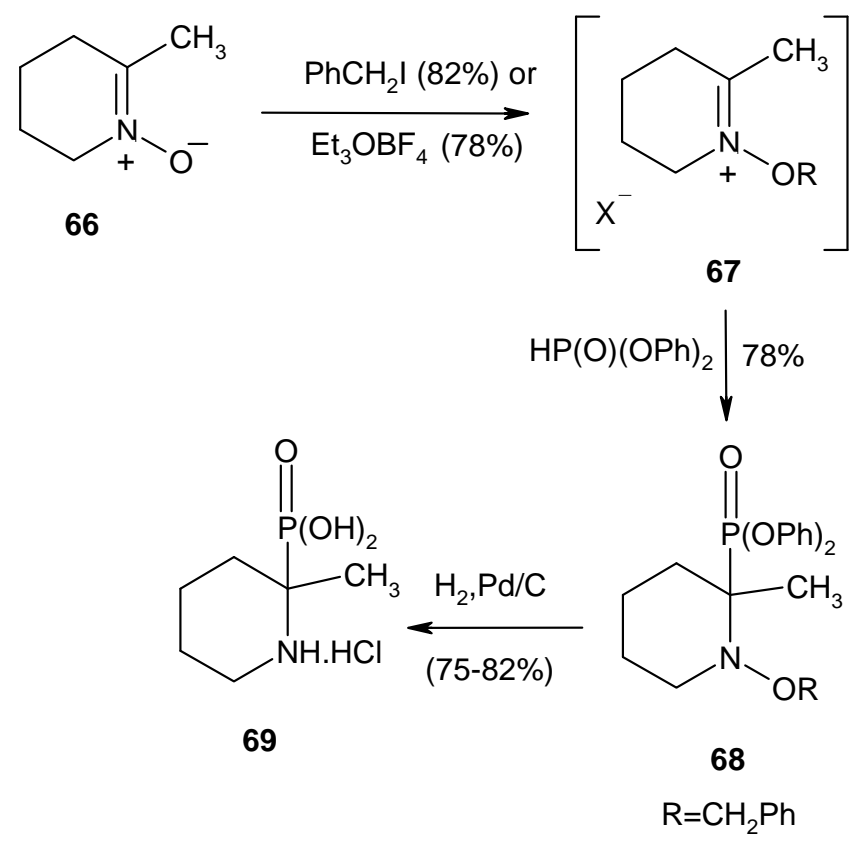

\section{Scheme 25}

\subsection{Nucleophilic phosphonylation}

The apparently most obvious method to synthesize cyclic $\alpha$-aminophosphonates, was started from the desired cyclic compound bearing a suitable leaving group such as acetate (AcO), phenylsulfinyl (PhSO), and benzotriazole $(\mathrm{Bt})$ in the $\alpha$-position to the $\mathrm{N}$ atom, which was then substituted by a phosphonate group. Thus, 1-( $p$-tosyl)-2-acetoxyazetidine (71) was synthesized from easily available compound $\mathbf{7 0}$ by anodic acetoxylation at the 2-position. Compound $\mathbf{7 1}$ was treated with 1.2 equivalents of trimethyl phosphite to obtain the corresponding 2-phosphonoazetidine (72) (Scheme 26). ${ }^{53}$

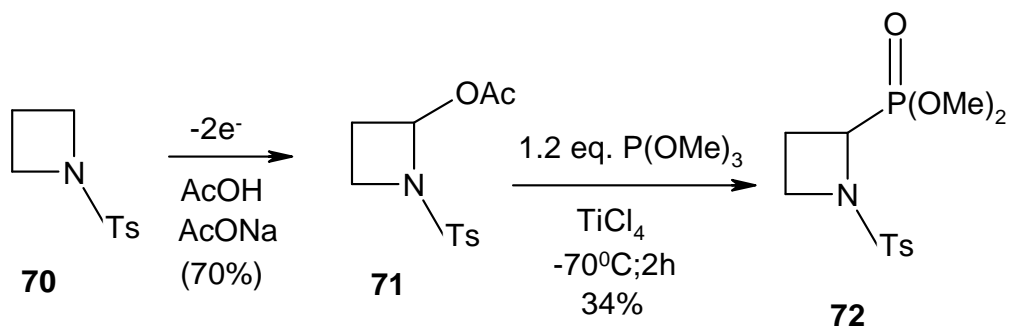

\section{Scheme 26}


When 4-acetoxyazetidin-2-one (73) was treated with trialkyl phosphite, phosphonylated azetidinones $\mathbf{7 4}$ were formed via an atypical Michaelis-Arbuzov reaction, together with the corresponding alkyl acetate. No reaction occurred with tris(2,2,2-trichloroethyl)phosphite because of its reduced nucleophilicity (Scheme 27). ${ }^{54}$

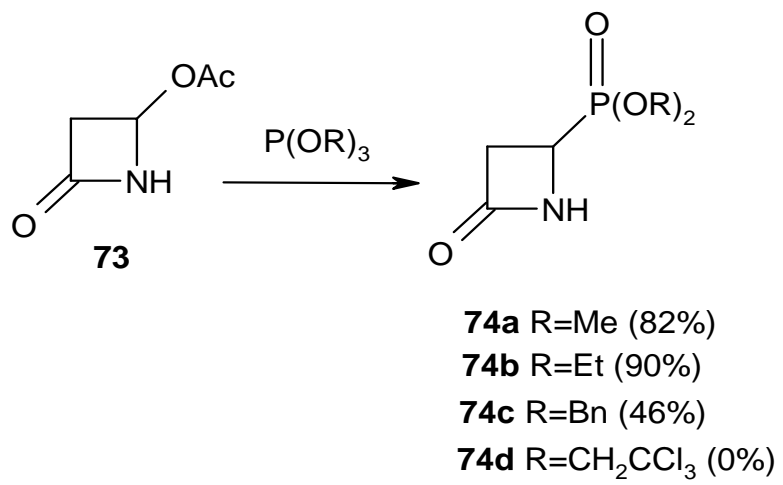

\section{Scheme 27}

The phthalimido derivative $\mathbf{7 5}$ was evaluated in the reaction with trimethyl phosphite. Campbell and Carruthers stated that the reaction led exclusively to the cis-product $\mathbf{7 7 a}(89 \%$ yield) (Scheme 28). ${ }^{55,56}$

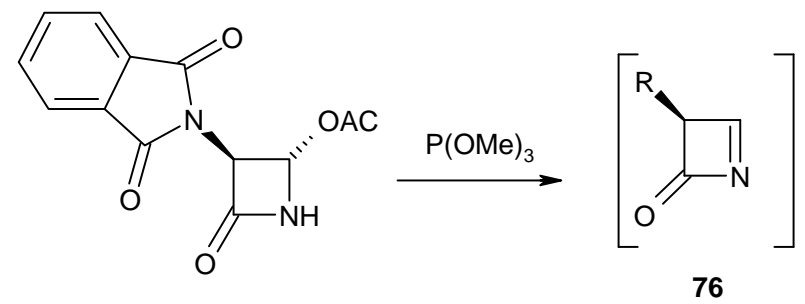

$(3 S, 4 S)-75$

76

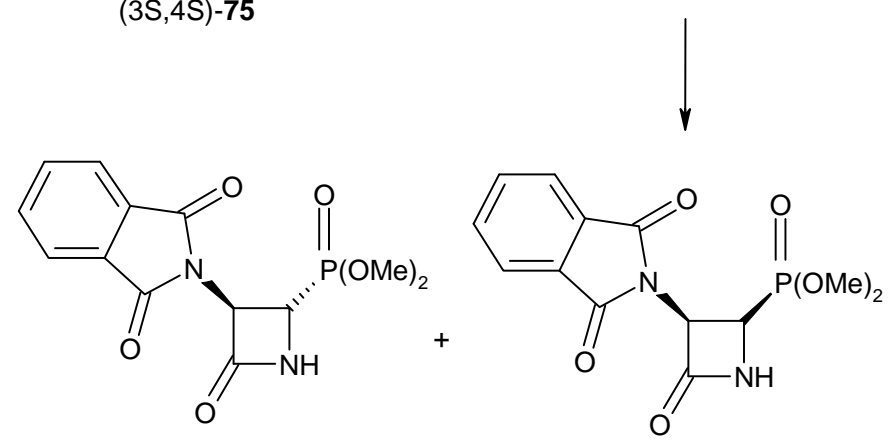

$(3 \mathrm{~S}, 4 \mathrm{~S})-77 \mathrm{~b}$

$(3 S, 4 S)-77 a$

\section{Scheme 28}


4-Sulfinylazetidin-2-one (78) was another substrate with an appropriate leaving group for a substitution reaction with a phosphonate group. Treatment of $\mathbf{7 8}$ with silylated phosphite in the presence of $\mathrm{ZnI}_{2}$ at room temperature for $6 \mathrm{~h}$ gave the 4-phosphonoazetidin-2-one (80) in $77 \%$ yield. ${ }^{57}$ Actually, this reaction was not a real substitution reaction, which was indicated by the stereochemistry of the reaction. Due to the action of the Lewis acid, a reactive iminium salt 79 was formed that reacted in situ with the trivalent phosphorus nucleophile (Scheme 29).<smiles>CO[Sb](=O)(OC)[C@H]1NC(=O)[C@@H]1[C@H](C)OS(=O)(=O)Br</smiles>

$(3 \mathrm{~S}, 4 \mathrm{R})-78$

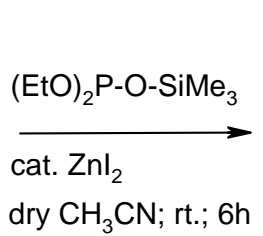

(77\%)

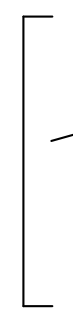

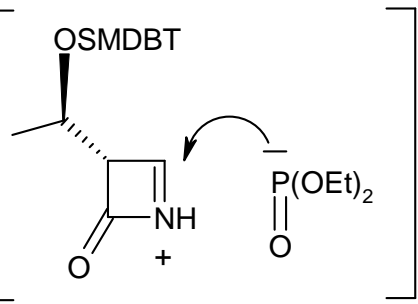

79
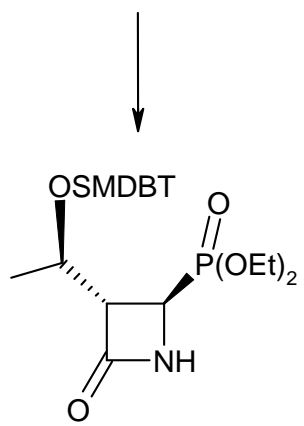

$(3 S, 4 R)-80$

\section{Scheme 29}

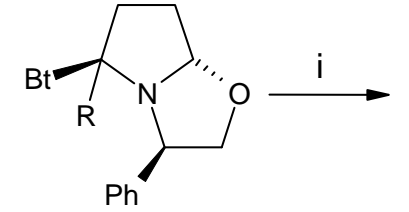

81 (3R, 5S,7aS)

$\mathrm{Bt}=$ benzotriazol-1-yl

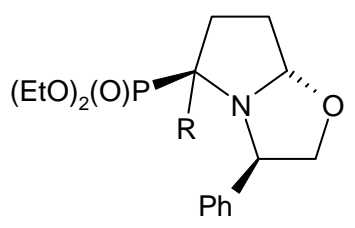

$82(3 R, 5 S, 7 a S)$

$\mathrm{R}=\mathrm{H} 77 \%$

$\mathrm{R}=\mathrm{Me} 83 \%$

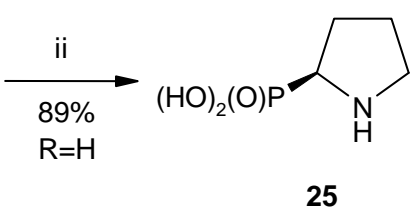

25

i) $\mathrm{P}(\mathrm{OEt})_{3}, \mathrm{ZnCl}_{2}\left(0.3\right.$ equiv), $\mathrm{CH}_{2} \mathrm{Cl}_{2}, 0^{\circ} \mathrm{C}$, overnight

ii) a. $\mathrm{H}_{2}, \mathrm{Pd} / \mathrm{C}$, b.6 $\mathrm{M} \mathrm{HCl}$, c. propylene oxide

\section{Scheme 30}

Subsequent Arbuzov reaction in the presence of the mild Lewis acid $\mathrm{ZnCl}_{2}$ or $\mathrm{ZnBr}_{2}$, converted $\mathbf{8 1}$ into the desired oxazolopyrrolidine phosphonate $\mathbf{8 2}$ as the only diasteroisomer. 
Attempts to obtain $\mathbf{8 2}$ directly by replacing benzotriazole with triethyl phosphite in the initial reaction mixture resulted in a mixture of two diastereoisomers. ${ }^{58-62}$ Hydrogenolysis of 82, followed by acidic hydrolysis of the phosphonate moiety with $6 \mathrm{M} \mathrm{HCl}$ and subsequent treatment with propylene oxide led to $(S)$-phosphopyrrolidine 25 (Scheme 30). ${ }^{59}$

Benzotriazol-1-yl $\left(\mathrm{Bt}^{1}\right)$ and benzotriazol-2-yl $\left(\mathrm{Bt}^{2}\right)$ are good leaving groups and give rise to the iminium cations. Thus, treatment of $\mathbf{8 3}$ in dry THF with triethyl phosphite in the presence of one equivalent of $\mathrm{ZnBr}_{2}$ produced phosphonopyrrolidinones $\mathbf{8 4}$ in moderate to good yields (Scheme 31). ${ }^{63}$

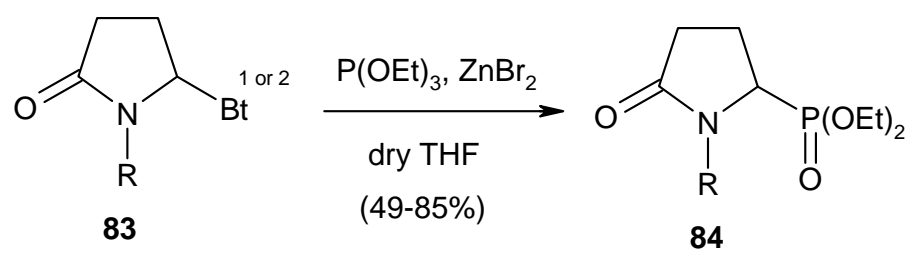

\section{Scheme 31}

An asymmetric synthesis of 5-phosphonopyrrolidone 87 was based on a similar principle. Here, the hemiaminal-like $\mathrm{C}-\mathrm{O}$ bond was cleaved by the action of $\mathrm{TiCl}_{4}$. The iminium ion $\mathbf{8 6}$ was then trapped by trimethyl phosphite with the formation of 87 in $62 \%$ diastereomeric excess (Scheme 32). ${ }^{64}$

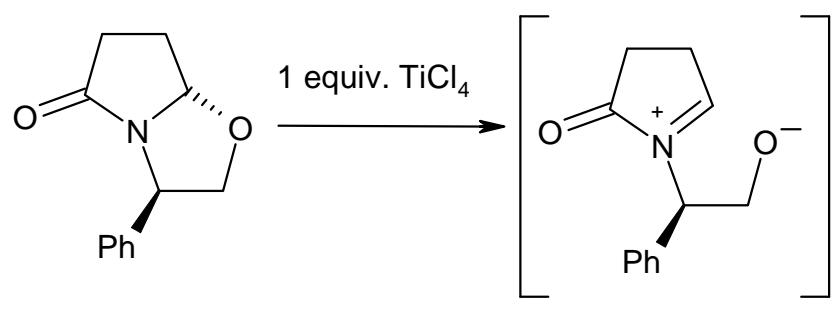

(3R,7aS)-(-)-85

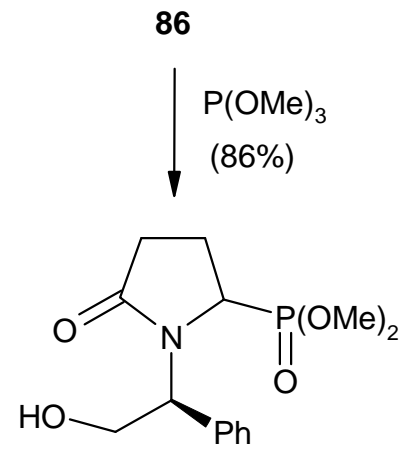

87(62\%)

Scheme 32 
Decarboxylation-phosphonylation reactions of (4R)-acetoxyproline derivative $\mathbf{8 8}$ with $\mathrm{PhI}(\mathrm{OAc})_{2} / \mathrm{I}_{2}$ under sunlight activation, followed by reaction with trimethyl phosphite in the presence of $\mathrm{BF}_{3} . \mathrm{OEt}_{2}$, afforded the cyclic $\alpha$-aminophosphonate $\mathbf{8 9}$ and its epimer $\mathbf{9 0}$ in $64 \%$ and $15 \%$ yield, respectively (Scheme 33$).{ }^{65,66}$<smiles>[CH]N1C[C@@H](OC(C)=O)CC1C(=O)O</smiles>

88

\section{1) $\mathrm{Ph}(\mathrm{OAc})_{2}, \mathrm{I}_{2}$, sunlight \\ 2) $(\mathrm{MeO})_{3} \mathrm{P}, \mathrm{BF}_{3}-\mathrm{OEt}_{2}$}

$\mathrm{AcO}$,<smiles>CO[P+](=O)C1C[C@H](C)CN1C1CCCCC1</smiles>

89<smiles>CO[P](=O)[C@@H]1C[C@@H](OC2CC2)CN1C1CCCCC1</smiles>

90

\section{Scheme 33}

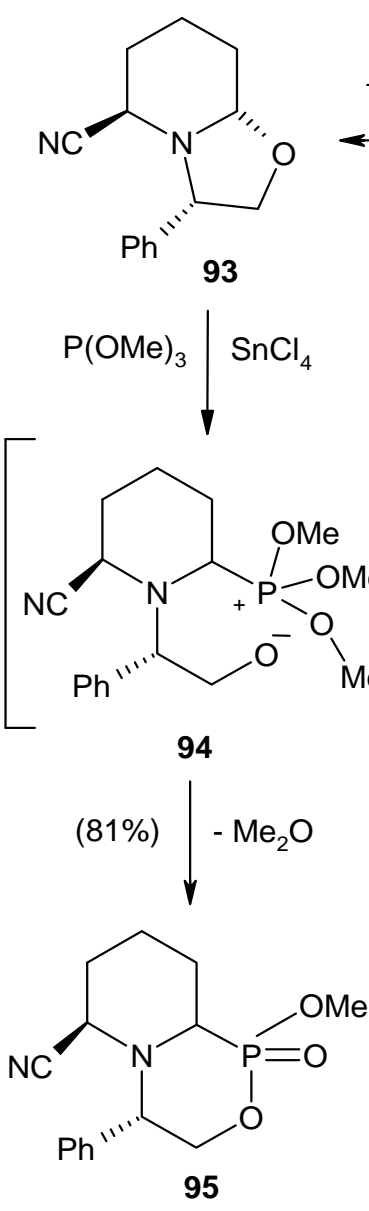

95<smiles>O=CCCCC=O</smiles>

91

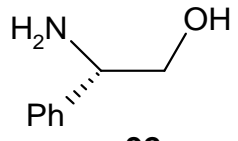

92

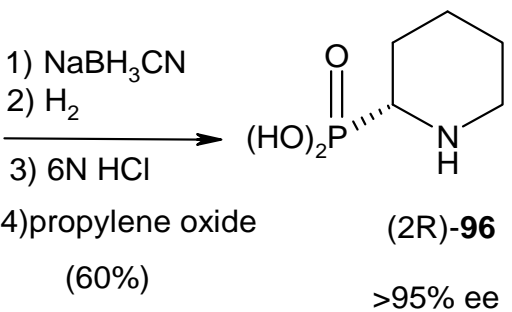

\section{Scheme 34}


Maury et $a l^{67}$ developed a strategy to synthesize both enantiomers of piperidin-2-yl phosphonic acid. The strategy utilized the oxazolopiperidine derivative 93, which upon treatment with trimethyl phosphite in the presence of $\mathrm{SnCl}_{4}$ gave the corresponding oxazaphosphorinane derivative 95, which then led to pure $(R)$-(-)-piperidin-2-ylphosphonic acid (96) in good overall yield after reduction and hydrogenolysis (Scheme 34$)$.

The oxazolopiperidine derivative 97 reacted with a triethyl phosphite in the presence of lithium diethyl phosphite to obtain a mixture of two diastereoisomers 98 (93:7, 68\% overall yield), which can be hydrogenated to the corresponding 2-phosphonopiperidine 99 in $86 \%$ ee (Scheme 35). ${ }^{68}$

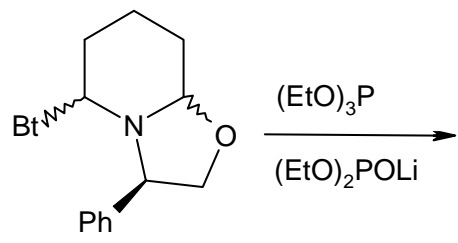

97

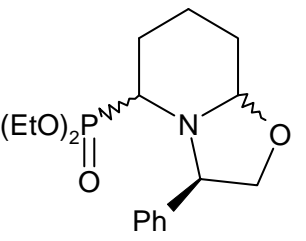

98

2 diastereomers $(93: 7)$ $\mathrm{Pd} / \mathrm{C}, \mathrm{H}_{2}$<smiles>CC[Pb](=O)[C@H]1CCCCN1</smiles>

(2R)-99

$(86 \%$ ee)

\section{Scheme 35}

The phosphonate moiety can easily be introduced onto methoxylated piperidines such as $\mathbf{1 0 0}$ in the presence of a Lewis acid by trapping the iminium ion with triethyl phosphite. ${ }^{69}$ This methodology was used to obtain the phosphonopiperidine 102 (Scheme 36). 


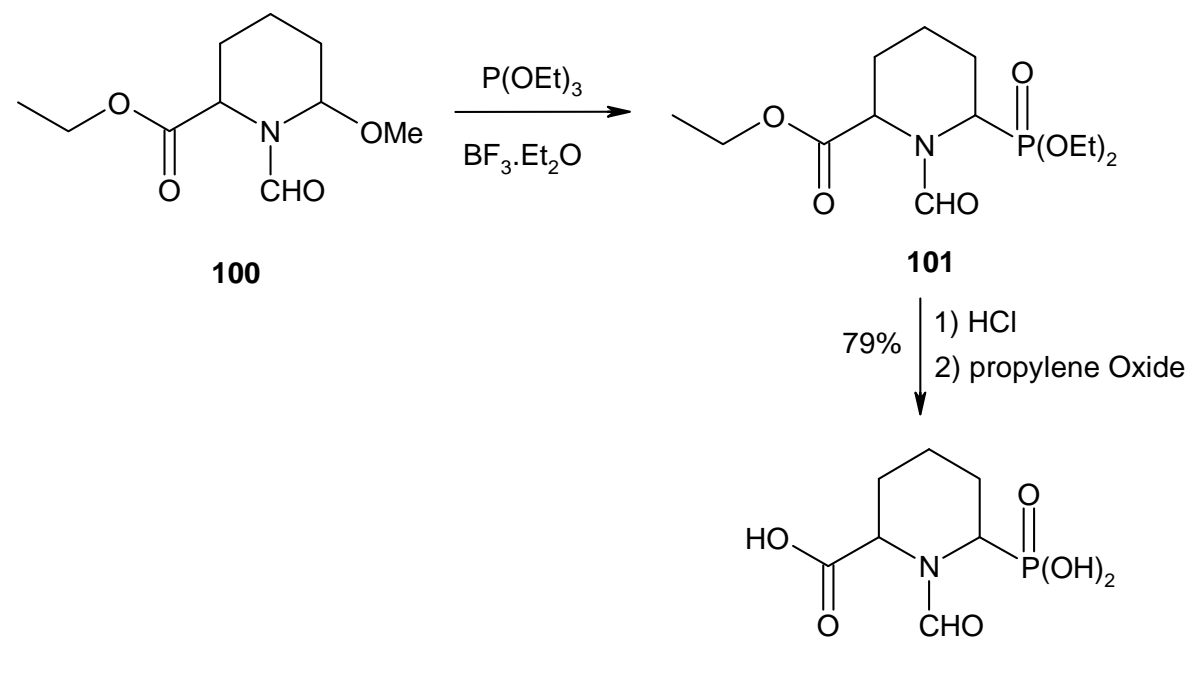

102

\section{Scheme 36}

\subsection{Multicomponent reaction (Kabachnik-Fields reaction)}

2-(Diethylphosphono)-2-methylpyrrolidine (104) was obtained in a one-pot reaction by bubbling ammonia into an ethanolic solution of 5-chloropentan-2-one (103) and diethyl phosphite (Kabachnik-Fields reaction) (Scheme 37). ${ }^{70,71}$

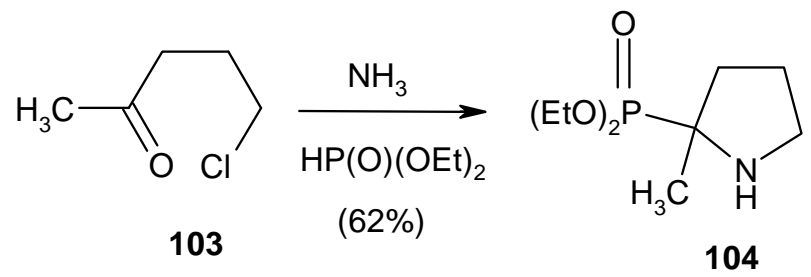

\section{Scheme 37}

Reaction of alkanedial (105), acetamide, and acetyl chloride with $\mathrm{PCl}_{3}$ in acetic acid exclusively produced the bisphosphonic acid 106a in 39\% yield. When the reaction was performed with pentanedial, the corresponding piperidine 106b was formed (33\%) in a 1:1 mixture with the acyclic bis(aminophosphonic acid) $\mathbf{1 0 7 b}$ (Scheme 38 ). ${ }^{72}$ 

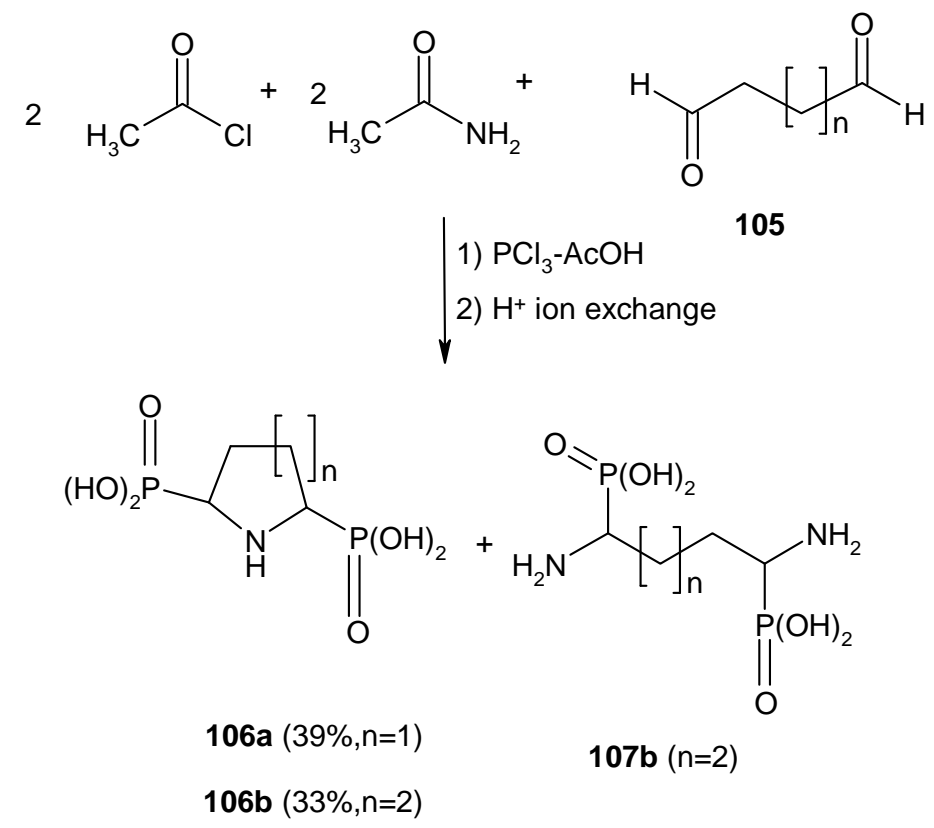

\section{Scheme 38}

\subsection{Diels-Alder reaction}

Davis and co-workers ${ }^{73}$ described [4+2] cycloadditions between azirinylphosphonates 108 with 2,3-dimethylbutadiene (109) or trans-piperylene 111. The diene (100 equivalents) was reacted with the phosphonoazirine for 2-4 days at room temperature. Bicyclic aziridines $\mathbf{1 1 0}$ and $\mathbf{1 1 2}$, respectively were isolated as single stereoisomers by flash chromatography. Catalytic hydrogenation of $\mathbf{1 1 0}$ results in two products. The major products, were identified as quaternary piperidinephosphonates (2S)-(-)-113, which resulted from the expected cleavage of the C-7-N bond in 110. The minor products, obtained in $28 \%$ and $13 \%$ yield, respectively, were identified as pyridines 114. Controlling the conditions for the hydrogenation of $\mathbf{1 1 2}$ led to the reduction of the C-C double bond, affording the phosphonopiperidine 115 (Scheme 39).

Diethyl 3-(diethoxyphosphoryl)-6-alkylpyridazine-1,2(3H,6H)-dicarboxylates (118) was obtained in $85 \%$ yield from cycloaddition reaction of 1,3-dienylphosphonates 116 with diethyl azidodicarboxylate (117) in dioxane. Compounds 118 were generally regarded to have a half chair configuration based on the relationship between the vicinal coupling constants and dihedral angles (Scheme 40). ${ }^{74}$

3-(Dimethylphosphino)piperidazine $\mathbf{1 2 1}$ can be synthesized via a Diels-Alder reaction of di-(-)menthyl azodicarboxylate (120) and 1-trimethylsilyloxybutadiene (119) in the presence of trimethyl phosphite and a Lewis acid, as an inseparable mixture of diastereomers (Scheme 41). However, after hydrogenation of 121, the phosphonopiperidazines 122 and 123 can easily be separated by column chromatography. ${ }^{75}$ 


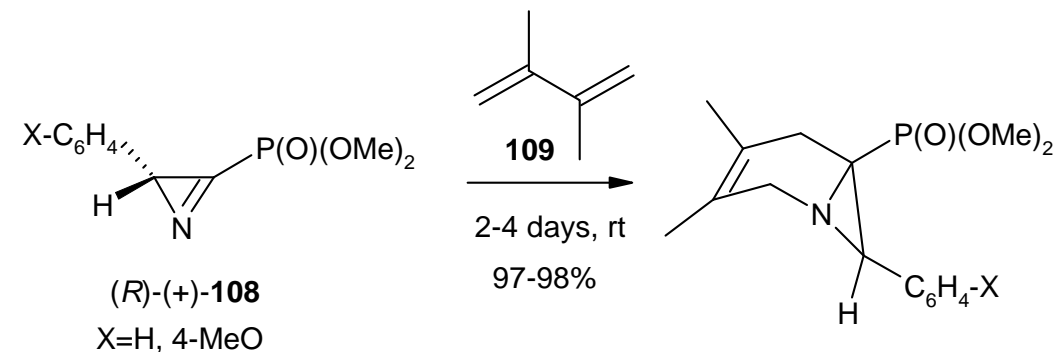

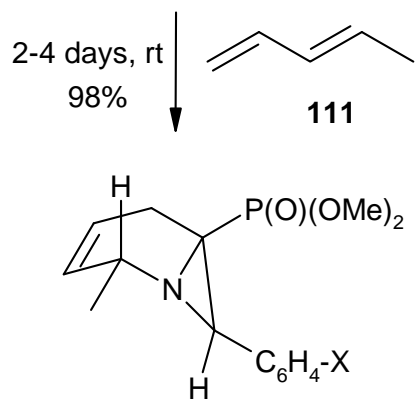

(6S, 7R)-(-)-112

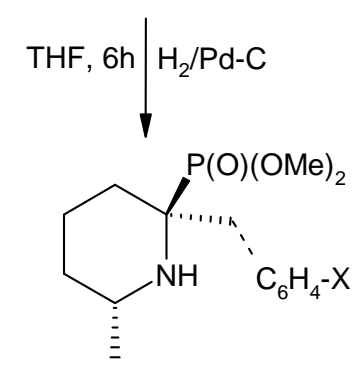

(2S,6R)-(-)-115

$40-81 \%$
(6S, 7R)-(-)-110

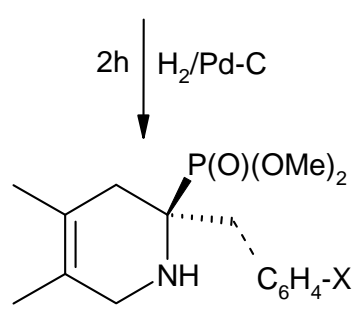

(2S)-(-)-113

$47-80 \%$

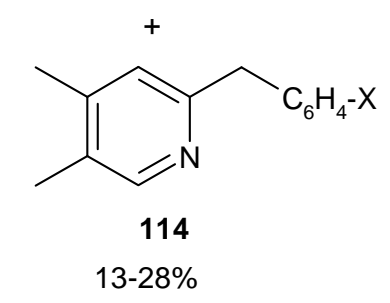

\section{Scheme 39}
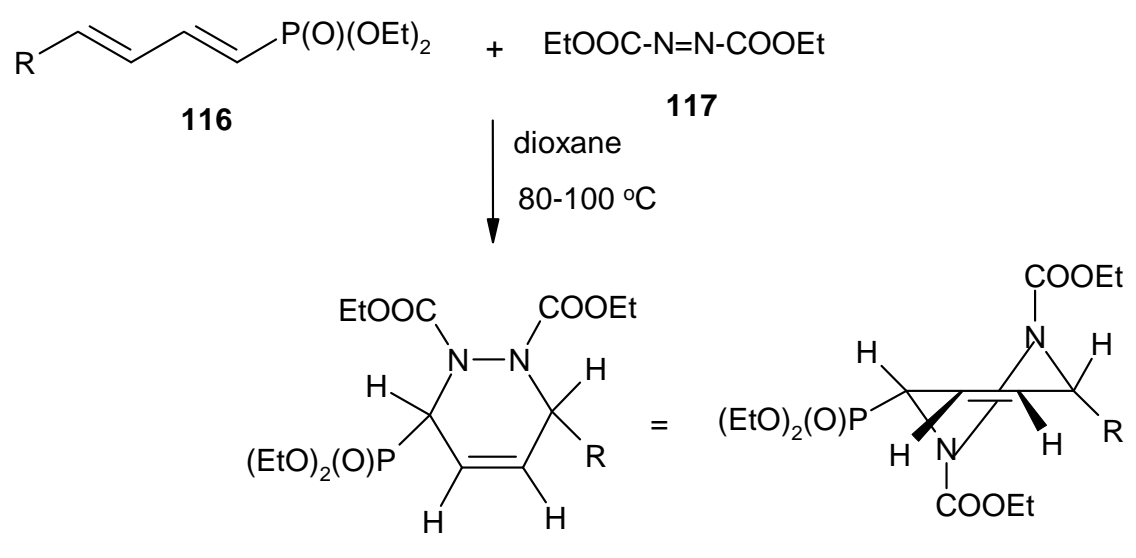

118

\section{Scheme 40}




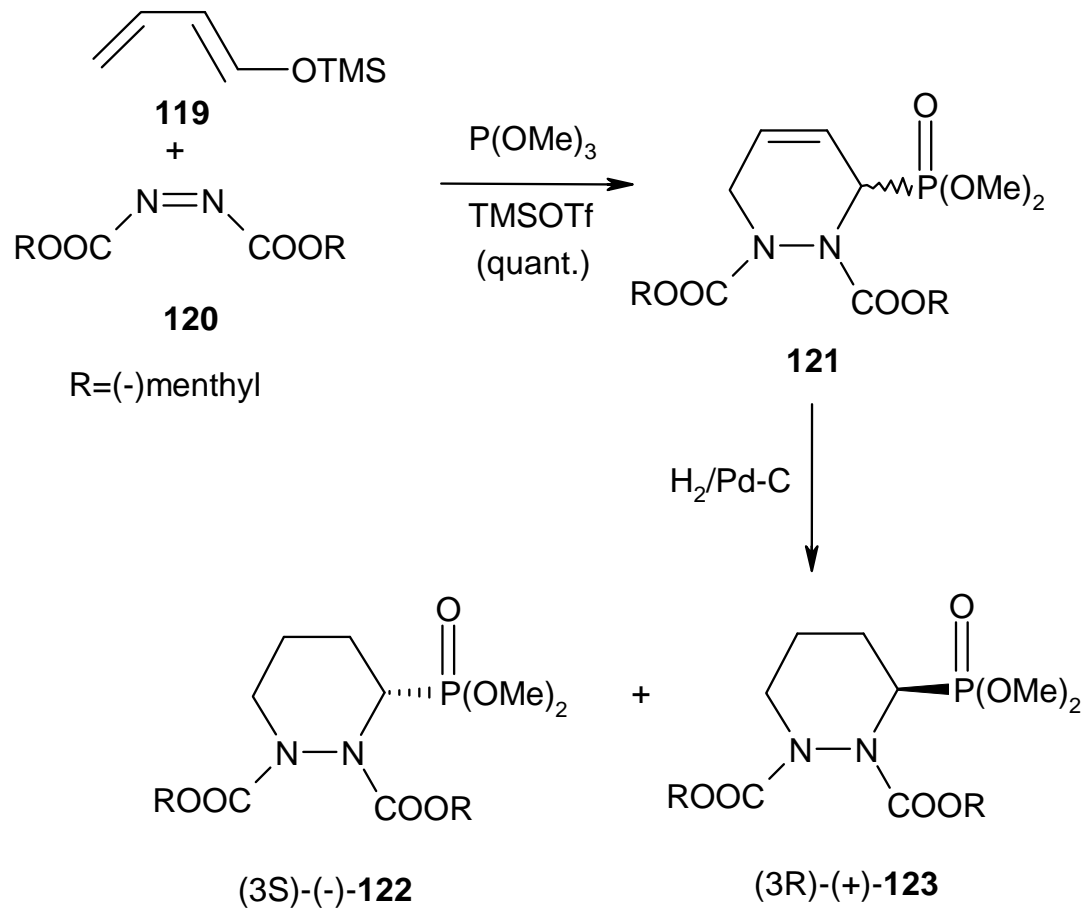

\section{Scheme 41}

\subsection{Ring closure of iminophosphonates}

Recently, an initial study was made on the reactivity of 1-phosphono-2-aza-1,3-dienes, ${ }^{76,77}$ which prove to be promising substrates for the synthesis of azaheterocyclic phosphonates. Reaction of the azadienes 124 with an excess of diazomethane led to the clean generation of 1-vinyl-2phosphonoaziridines $\mathbf{1 2 5}$ in good yields (Scheme 42).

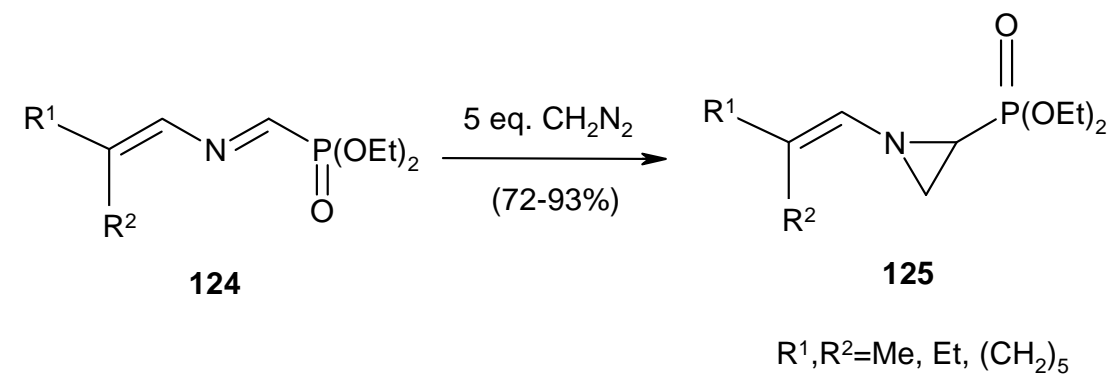

\section{Scheme 42}

Reaction of carbanions of $N$-phosphonomethyl imines 126 with $\alpha, \beta$-unsaturated esters 127 can lead to three different products: an acyclic adduct $\mathbf{1 2 9}$ due to Michael addition, pyrroline $\mathbf{1 3 1}$ due to cycloaddition and subsequent elimination of the diethyl phosphate anion, or pyrrolidine 130. When sodium hydride was used as a base at room temperature, pyrrolidines 130 were 
formed exclusively in good yields $(77-90 \%)$ due to the stereospecificity of the reaction related to the concerted mechanism (Scheme 43). ${ }^{78-80}$<smiles></smiles>

126

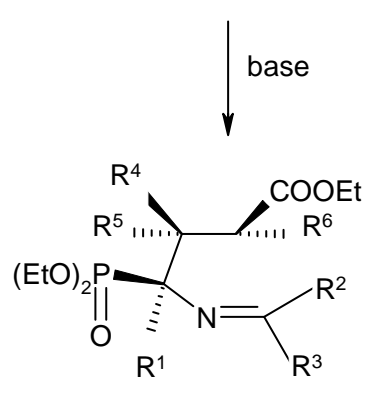

129

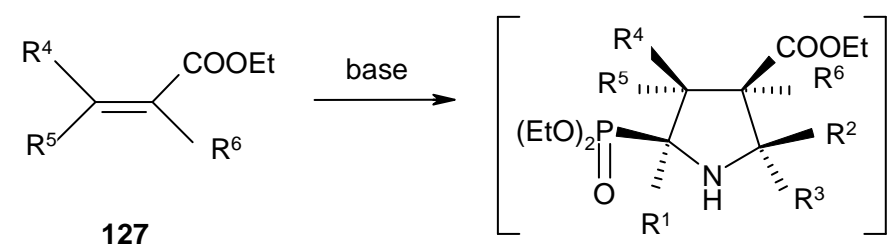

128

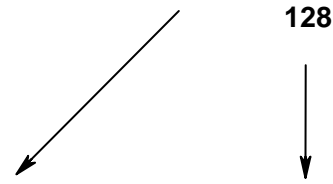

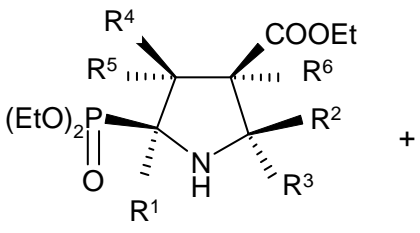

130

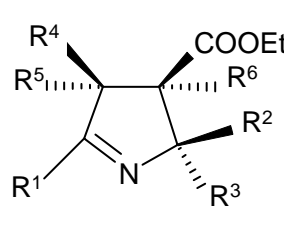

131

\section{Scheme 43}

The metal-catalyzed cycloaddition reactions of $\alpha$-iminophosphonate 132 with various dipolarophiles including chiral menthyloxy furanone with (AgOAc) or ( $\mathrm{LiBr}$ ) and a suitable base [DBU, $\mathrm{Et}_{3} \mathrm{~N}, \mathrm{BTMG}$ ( $t$-butyltetramethylguanidine)] afforded a wide variety of conformationally constrained cyclic $\alpha$-aminophosphonate 135 (Scheme 44). ${ }^{81}$

The imine 136 was alkylated, followed by ring closure via hydrolysis by trifluoroacetic acid to give the 2-phosphonopyrrolidinone 138 (Scheme 45). When hydrochloric acid was used, no cyclization occurred and the corresponding hydrochloride salt of the acyclic amine was recovered from the reaction mixture. ${ }^{82}$

When unsubstituted acrylic esters ${ }^{83-85}$ were used in the addition reaction, only $\mathrm{ZnCl}_{2}$ generated carbanions of 139 were reactive. Iminophosphonate 140 was formed in $66 \%$ yield with $71 \%$ de. The minor diastereomer was easily removed by flash chromatography on silica gel. After hydrolysis, enantiomerically pure (5S)-pyroglutamic acid derivative 141 was isolated. The chiral auxiliary was recovered in $60 \%$ yield (Scheme 46 ). 

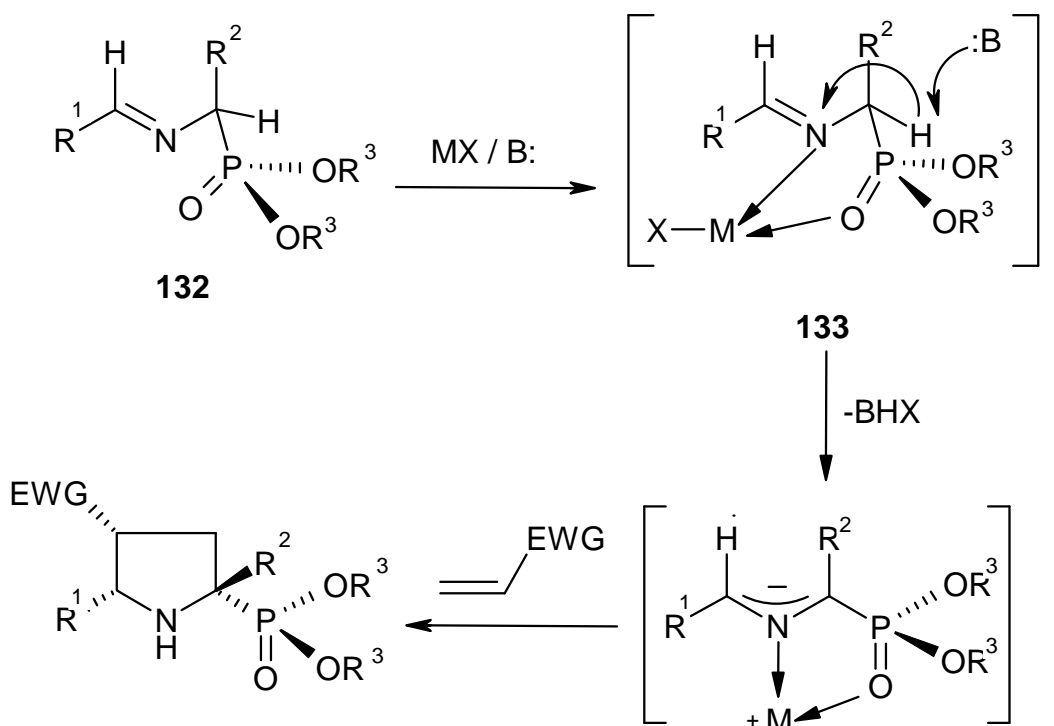

135

$$
\begin{aligned}
& \mathrm{R}^{1}=\mathrm{H}, \mathrm{Me}, \mathrm{Ph}, \mathrm{PhCH}_{2} \\
& \mathrm{R}^{2}=\mathrm{Me}, \mathrm{Et} \\
& \mathrm{R}^{3}=\mathrm{Me}, \mathrm{Et}
\end{aligned}
$$

\section{Scheme 44}
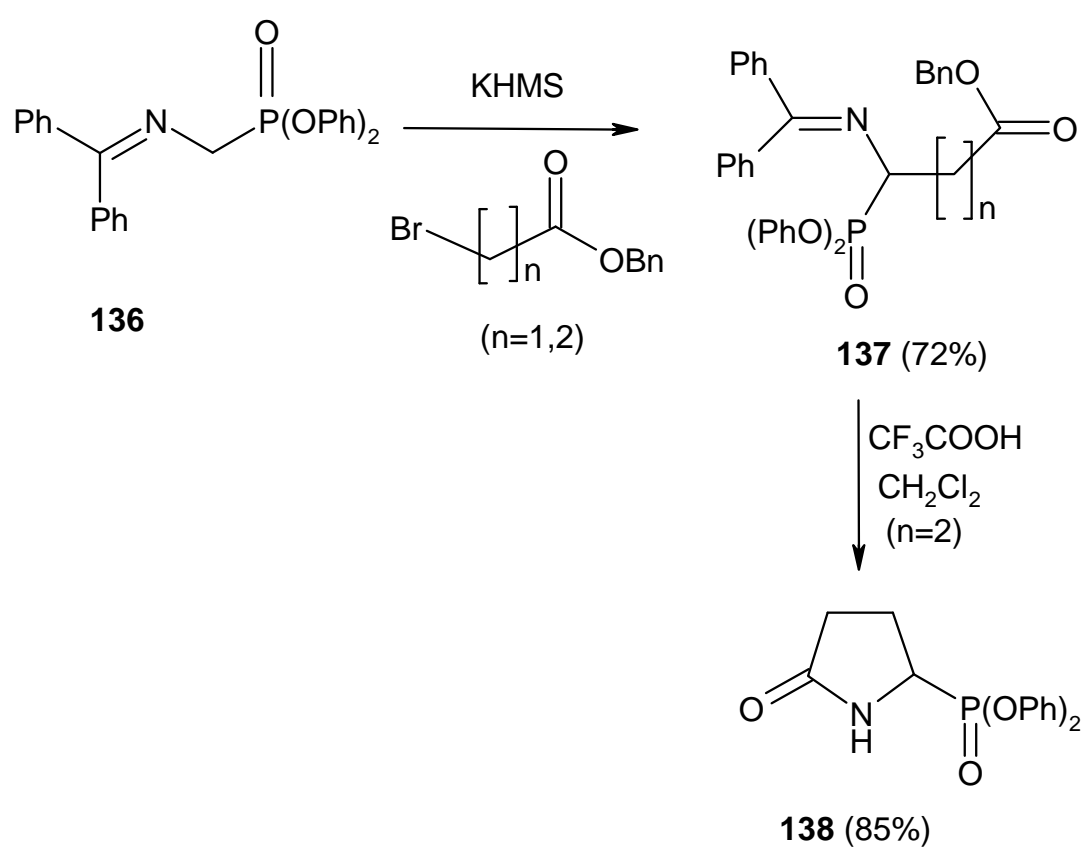

\section{Scheme 45}



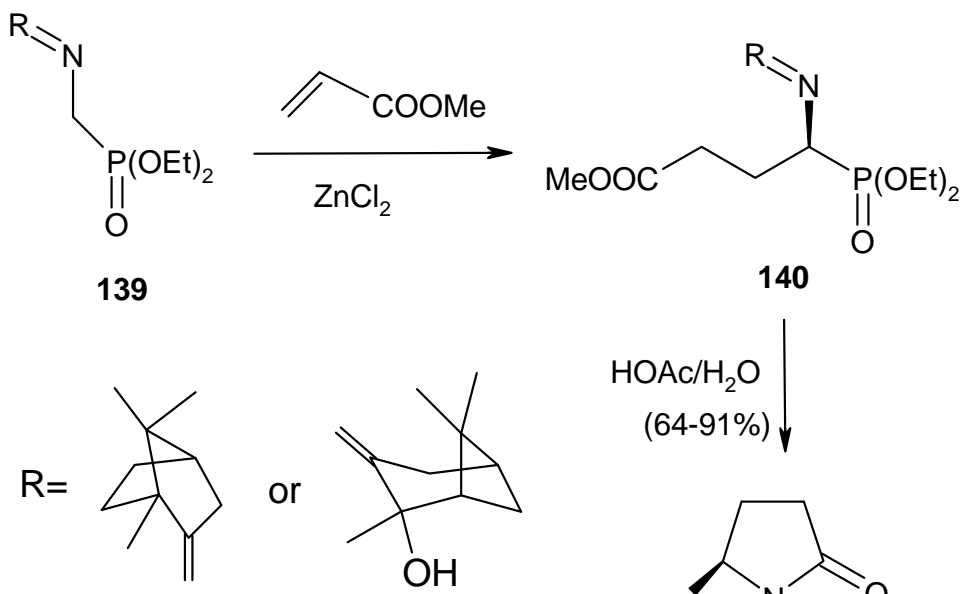

or
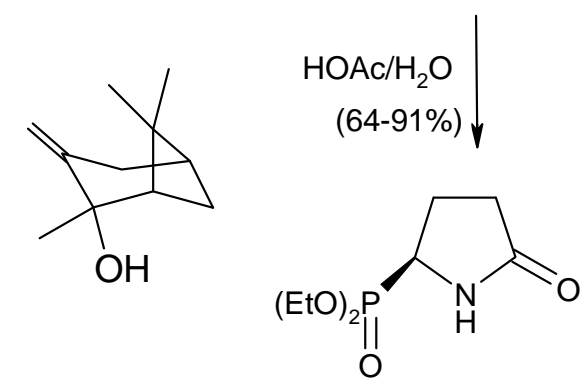

(5S)-141

$(\mathrm{ee}>95 \%)$

\section{Scheme 46}

Treatment of $N^{1}$-(diethoxyphosphorylmethyl)- $N^{2}$-(pentamethylene)benzamide (142) with $n$ butyllithium followed by the addition of $p$-tolualdehyde led to the formation of diethyl (trans and cis-2-phenyl-5-alkyl/aryl-oxazolin-4-yl)phosphonates 144 in good yields (Scheme 47). ${ }^{86}$

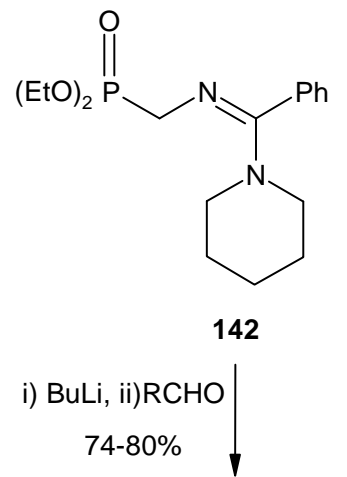<smiles>[R]C1OC([PH2+])=N[C@@H]1[PH](=O)OCC</smiles><smiles>[R]C1OC(c2ccccc2)=NC1P=O</smiles>

144-trans

144-cis

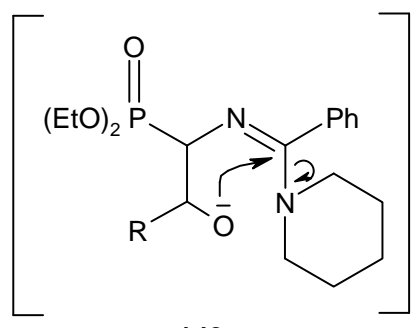<smiles>C1CCNCC1</smiles>

$\mathrm{R}=\mathrm{Me}, 4-\mathrm{MeC}_{6} \mathrm{H}_{4}$

\section{Scheme 47}


Methyl mercaptoacetate was added to a stirred solution of the diethyl trifluoroacetimidoylphosphonate (145) in benzene to give the nonisolable intermediate 146 which was directly cyclized into cyclic $\alpha$-aminophosphonate 147 (Scheme 48). ${ }^{87}$<smiles>CCO[PH](=O)C(=NC)C(F)(F)F</smiles>

145

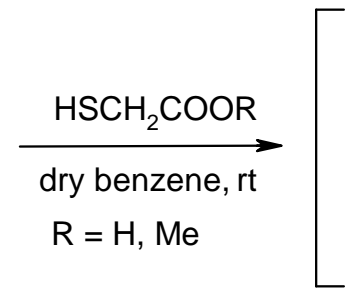<smiles>[R]OC(=O)CCCC(=O)OCC</smiles>

\section{6}

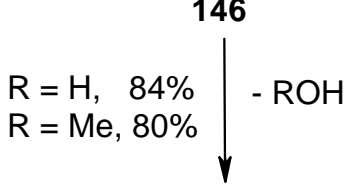<smiles>CCO[PH](=O)C1(C(F)(F)F)NC(=O)CS1</smiles>

147

\section{Scheme 48}

\subsection{Ring closure of oximinophosphonates}

The preparation of the required functionalized $\beta$-tosyl oximes 149 was easily accomplished by simple reaction of $\beta$-oximes 148 with tosyl chloride in pyridine. Alkyl and phenyl substituted $2 H$-azirines 150 were prepared from $\beta$-ketoximes 149 by treatment with triethylamine at room temperature for 8 hours in dry benzene. Reduction of $\mathbf{1 5 0}$ with sodium borohydride in ethanol gave exclusively cis-aziridines $\mathbf{1 5 1}$ (Scheme 49). ${ }^{88,89}$

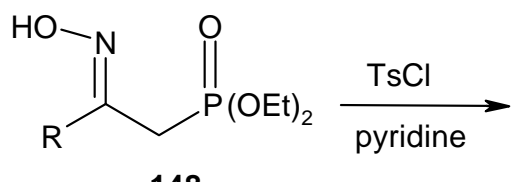

148

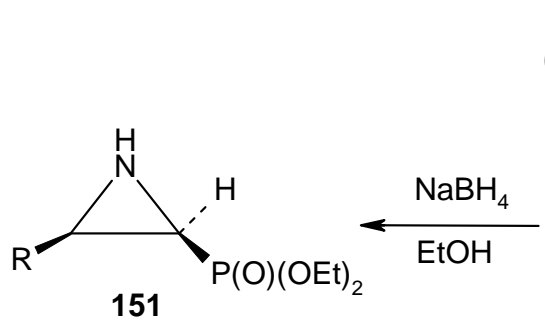

$\mathrm{R}=\mathrm{Me}, \mathrm{Et}, \mathrm{Ph}$<smiles>[R]C(C[P+](=O)OCC)=NO[As]</smiles>

149
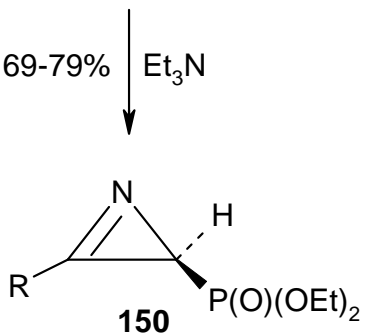

Scheme 49 
Chlorobutyryl chloride (152) was allowed to react with trialkyl phosphite. Then the oxime 154 was formed and ring closure was performed after reduction of the oxime with zinc and formic acid to give the cyclic $\alpha$-aminophosphonates 155 (Scheme 50). ${ }^{90}$

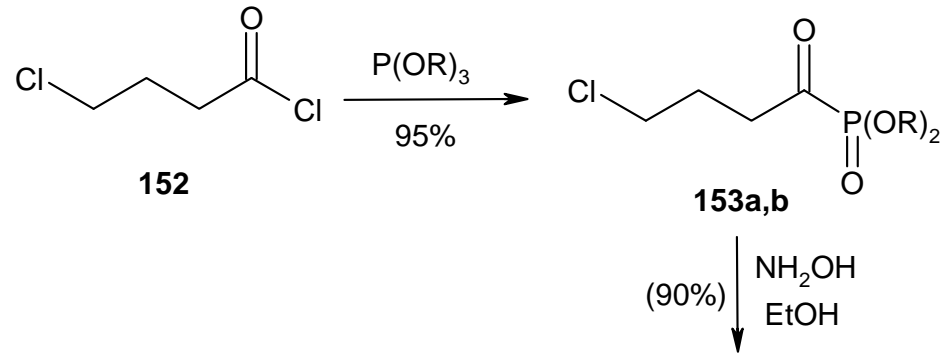

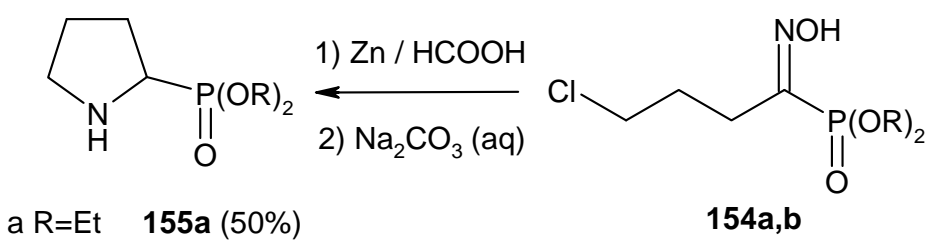

b R=n-Bu 155b (35\%)

\section{Scheme 50}

\subsection{Ring closure of acyclic $\alpha$-aminophosphonates}

Treatment of phosphoserine diethyl ester $(R)$-156 with tosyl chloride afforded the corresponding $N$-tosylate $(R)$-157, which, by reaction with mesyl chloride, afforded the $O$-mesylate derivative $(R)$-158. Reaction of $(R)-\mathbf{1 5 8}$ with $\mathrm{NaH}$ in THF gave the aziridine-2-phosphonate $(R)-\mathbf{1 5 9}$ (Scheme 51). ${ }^{91}$<smiles>CCO[PH](=O)[C@H]([NH3+])CO</smiles>

(R)-156

(R)-157

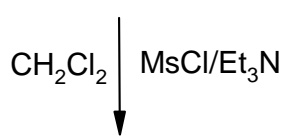

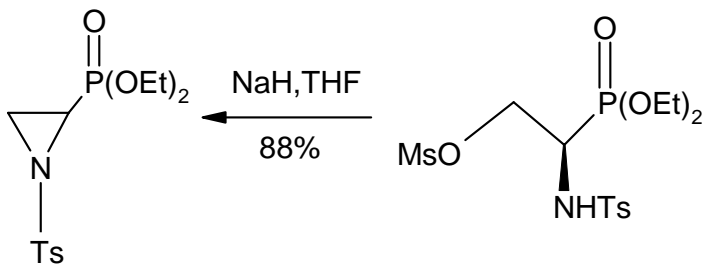

(R)-159

(R)-158

\section{Scheme 51}


Similarly, Guseinov et al. ${ }^{92}$ reported that acyclic $\alpha$-aminophosphonate 160 was transformed into phosphonate-containing aziridines $\mathbf{1 6 1}$ by the action of sodium alkoxide (Scheme 52).<smiles>[R]O[R20](=O)O[R6]([H])([H])C(NC([R])=O)C1(Cl)CCOC1=O</smiles>

160

161

\section{Scheme 52}

Ring closure through intramolecular nucleophilic substitution was applied in the synthesis of phosphono- $\beta$-lactams. The first example consists of an epoxide ring opening by intramolecular attack of a phosphorus-stabilized carbanion (Scheme 53). The epoxide 163 was formed in situ by addition of one equiv of LiHMDS (lithium 1,1,1,3,3,3-hexamethyldisilazane) to amide 162. A second equivalent was used to form the lactam 164 in a stereospecific manner: only the trans- $\beta$ lactams were formed. Nitrogen deprotection can then be performed using CAN (cerium ammonium nitrite), and the obtained 4-phosphono- $\beta$-lactams $\mathbf{1 6 5}$ are potential precursors for the synthesis of carbapenems. ${ }^{93-95}$

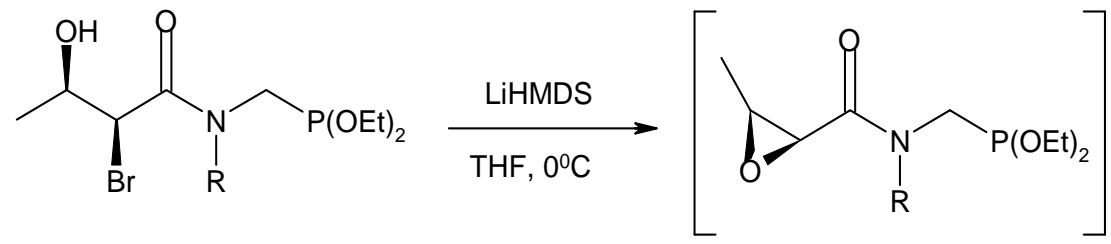

(2S,3R)-162

$\mathrm{R}=p-\mathrm{MeOPh}, p-\mathrm{MeOBn}$

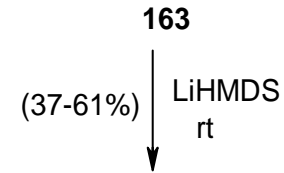<smiles>CCO[PH](=O)[C@H]1NC(=O)[C@H]1C(C)O</smiles>

(3S,4R,1'R)-165

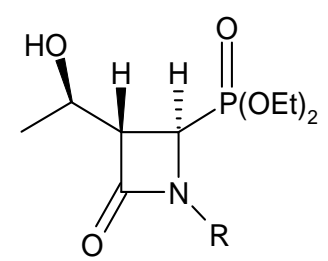

(3S,4R,1'R)-164

\section{Scheme 53}


Chloroamidophosphonates $\mathbf{1 6 6}$ were treated with $\mathrm{NaH}$ to involve ring closure to give the cyclic $\alpha$-aminophosphonates 167 (Scheme 54). ${ }^{96,97}$<smiles>[R]N(C(=O)CCl)C([Al])[P+]([R20])[R20]</smiles>

166

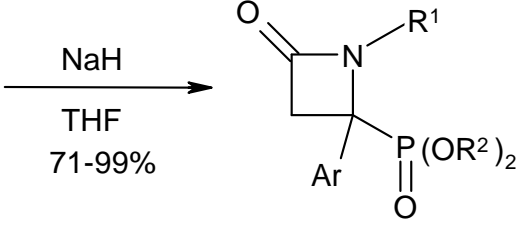

167

Ar=Ph, Furyl, Cinnamyl

$\mathrm{R}^{1}=\mathrm{Bn}$, Naphthyl

$\mathrm{R}^{2}=\mathrm{Me}, \mathrm{Et}$

\section{Scheme 54}

Treatment of the $\alpha$-aminophosphonate $\mathbf{1 6 8}$ with thionyl chloride in dichloromethane, followed by the addition of $\mathrm{NaHCO}_{3}$ gave the chloro derivative 169. Reaction of 169 with LiHMDS in THF afforded only the 1,3-trans-azetidine 170, which, on hydrolysis of the phosphonate moiety with TMSBr, followed by purification by ion-exchange chromatography, led to azetidin-2-ylphosphonic acid 171 (Scheme 55). ${ }^{98}$<smiles>CCOC(=O)CN(Cc1ccccc1)[C@@H](CCl)c1ccccc1</smiles>

168

169

$75 \% \mid \begin{aligned} & \text { LiHMDS,THF } \\ & -78 \text { to } 0^{\circ} \mathrm{C}\end{aligned}$<smiles>O=[P+](O)[C@@H]1C(c2ccccc2)CN1Cc1ccccc1</smiles>

171

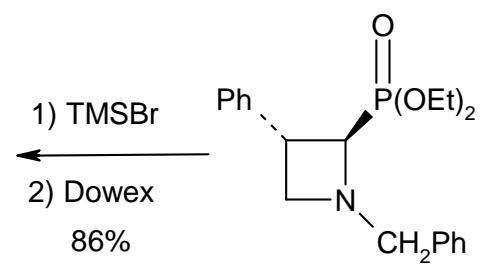

170

\section{Scheme 55}


The cyclization of the $\delta$-chloro- $\alpha$-aminobutanephosphonic acid (172), resulted in the racemic pyrrolidine-2-phosphonic acid $\mathbf{2 5}$ which has received some interest as a potential structural mimetic of proline (Scheme 56). ${ }^{99}$<smiles>NC(CCCCl)[P+](=O)[O-]</smiles>

172<smiles>O=[Pb](O)C1CCCN1</smiles>

25

\section{Scheme 56}

$\alpha$-Aminophosphonates 173 underwent tandem acylation and [4+2] cycloaddition with maleic anhydride under stirring in toluene at ambient temperature for 3 days to isolate epoxyisoindolyl phosphonates 174 in good yields (70-90\%) as colorless solids (Scheme 57). ${ }^{100}$<smiles>[R]CNC(c1ccco1)P(=O)(OC)OC</smiles>

173
Maleic anhydride

Toluene, 3 days, r.t

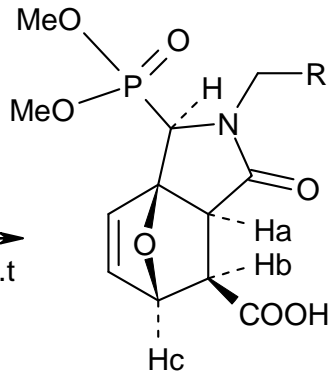

174

$\mathrm{R}=\mathrm{H}, \mathrm{Ph}, 2$-furyl, piperonyl, 4-FC ${ }_{6} \mathrm{H}_{4}$

\section{Scheme 57}

Adding one equivalent of Grubbs second-generation catalyst to the substrates $\mathbf{1 7 5}$ via ring closure methasis (RCM) gave the corresponding 2-phosphonopyrrolines $\mathbf{1 7 6}$ (Scheme 58). ${ }^{101}$<smiles>[R4]C=C([R])C([R](C)=O)N(CC#C)Cc1ccccc1</smiles>

175

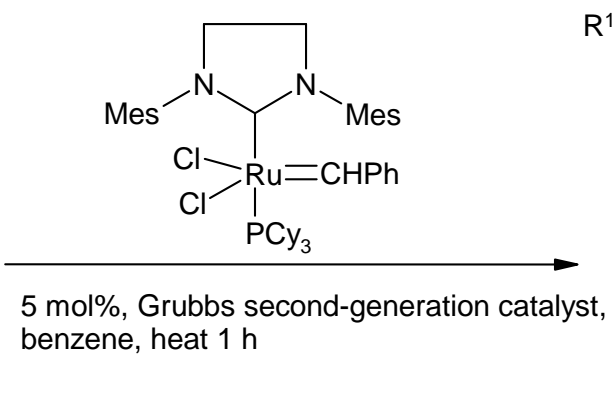

5 mol\%, Grubbs second-generation catalyst, benzene, heat 1 h

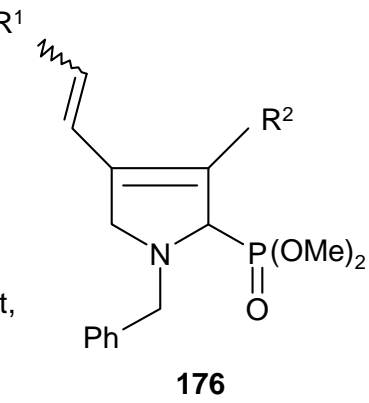

$\mathrm{R}^{1}=\mathrm{Me}, \mathrm{Pr}, \mathrm{Ph}, 2$-furyl, isopropyl $\mathrm{R}^{2}=\mathrm{H}, \mathrm{Me}, \mathrm{Ph}$

\section{Scheme 58}


When $\beta$-allenic $\alpha$-aminophosphonates $\mathbf{1 7 7}$ were heated in the presence of silver salts to activate the allenic moiety, a mixture of five- and six-membered heterocycles was obtained. The ratio of five-membered to six-membered rings was dependent on steric factors. When $\mathrm{R}^{1}$ and $\mathrm{R}^{2}$ were more sterically demanding groups, the ratio shifted toward the five-membered ring. The largest effect, however, was observed when $\mathrm{R}^{3}$ was changed from $\mathrm{H}$ to $\mathrm{Me}$; then, only very small amounts of six-membered rings $\mathbf{1 8 1}$ were formed. When the obtained pyrrolines 182 were submitted to high temperatures $\left(80{ }^{\circ} \mathrm{C}\right)$ under an inert atmosphere, the enamines 183 were formed by tautomerization to the more thermodynamically stable compound (Scheme 59). ${ }^{102,103}$

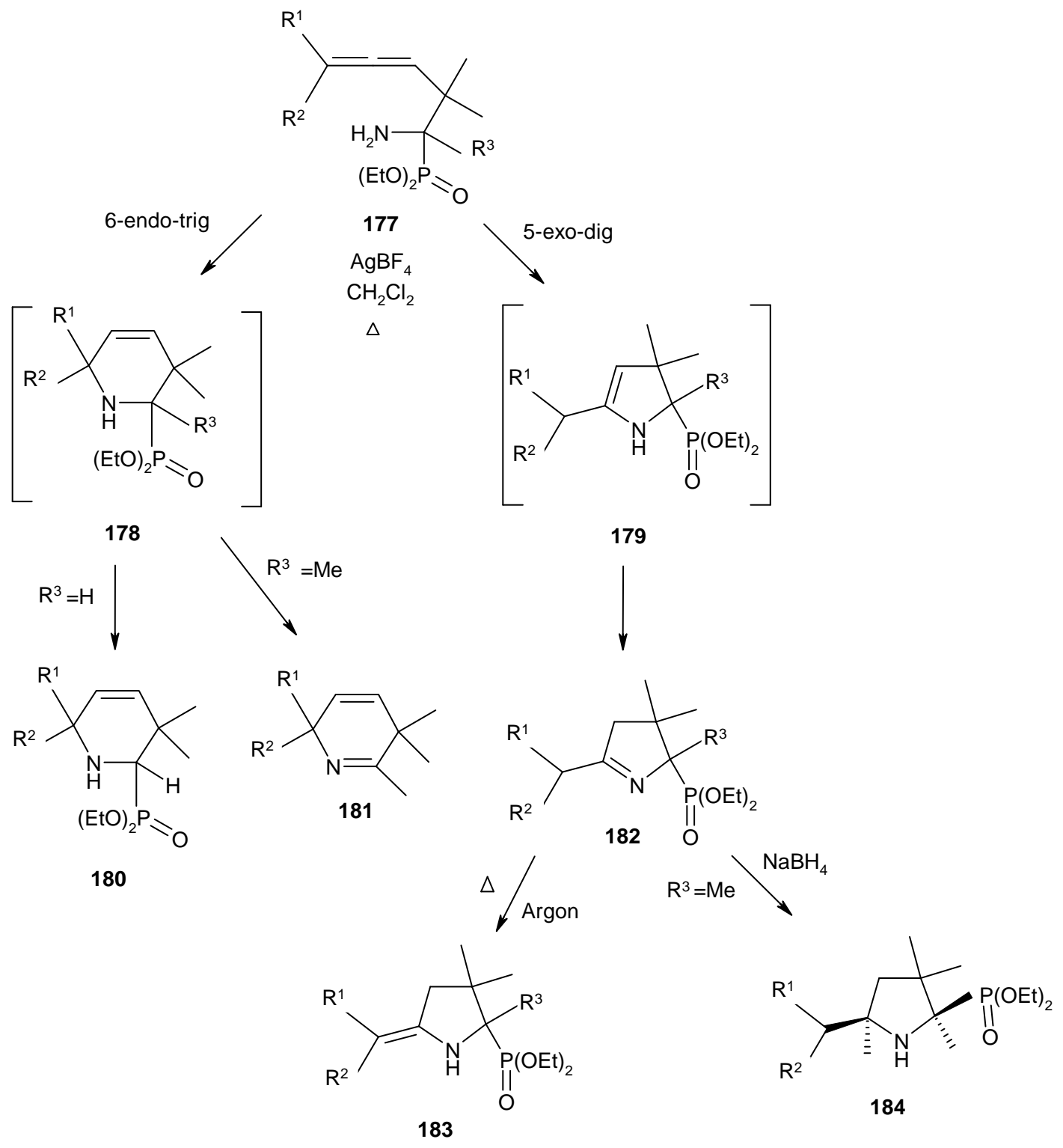

\section{Scheme 59}


Diethyl (6-isobutylamino)bicyclo[3,2,0]hept-2-en-6-yl phosphonate (185) was reacted with $\mathrm{HBr}$ and $\mathrm{Br}_{2}$ to give the hydrobromide salt 186, which underwent ring closure by addition of triethylamine and heating of the mixture in acetonitrile for 14 hours to give diethyl endo-(8bromo-2-isobutyl-2-azatricycle[3,3,0,0 $\left.{ }^{3,6}\right]$ oct-3-yl)phosphonate (187) (Scheme 60). ${ }^{104}$

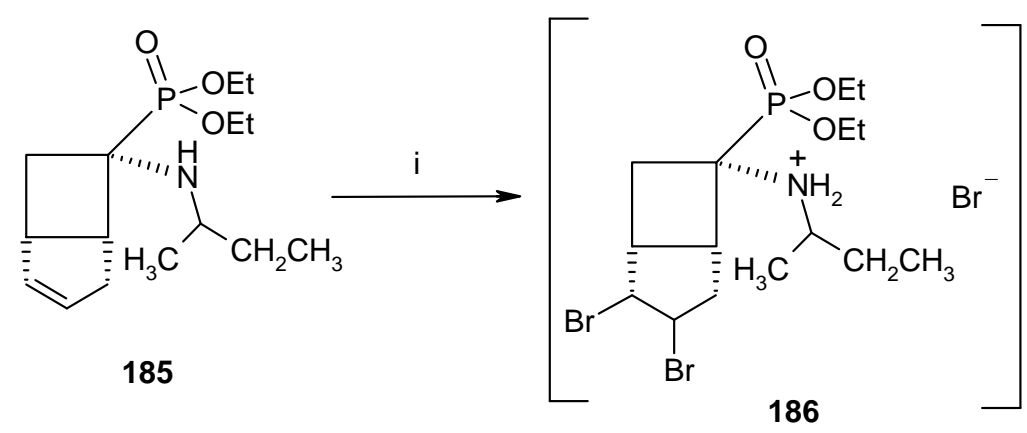

i) 1.05 equiv. $\mathrm{HBr}, 1.05$ equiv. $\mathrm{Br}_{2}$, extraction with $\mathrm{NaHCO}_{3}$
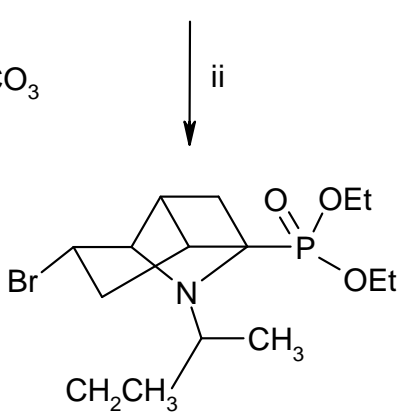

\section{Scheme 60}

Cyclization of the R- $\alpha$-amino- $\delta$-alkenylphosphonates $\mathbf{1 8 8}$ was initiated by addition of $\mathrm{Hg}(\mathrm{OAc})_{2}$ to the double bond followed by cyclization through intramolecular nucleophilic attack by the free amine. Using $\alpha$-amino- $\delta$-alkenylphosphonates, it was possible to obtain the five- and six-membered rings containing the $\alpha$-aminophosphonate moiety (Scheme 61). ${ }^{105-107}$ 1,4-Addition of lithiated aminomethylphosphonate 195 to $\alpha, \beta$-unsaturated ester 194 proceeded to give the dibenzylaminophosphonate 196 in 94\% yield and 98\% diastereomeric excess. Reductive deprotection of 196 then led to trans-phosphonopyrrolidone 197 in 66\% yield (Scheme 62). ${ }^{108}$ 


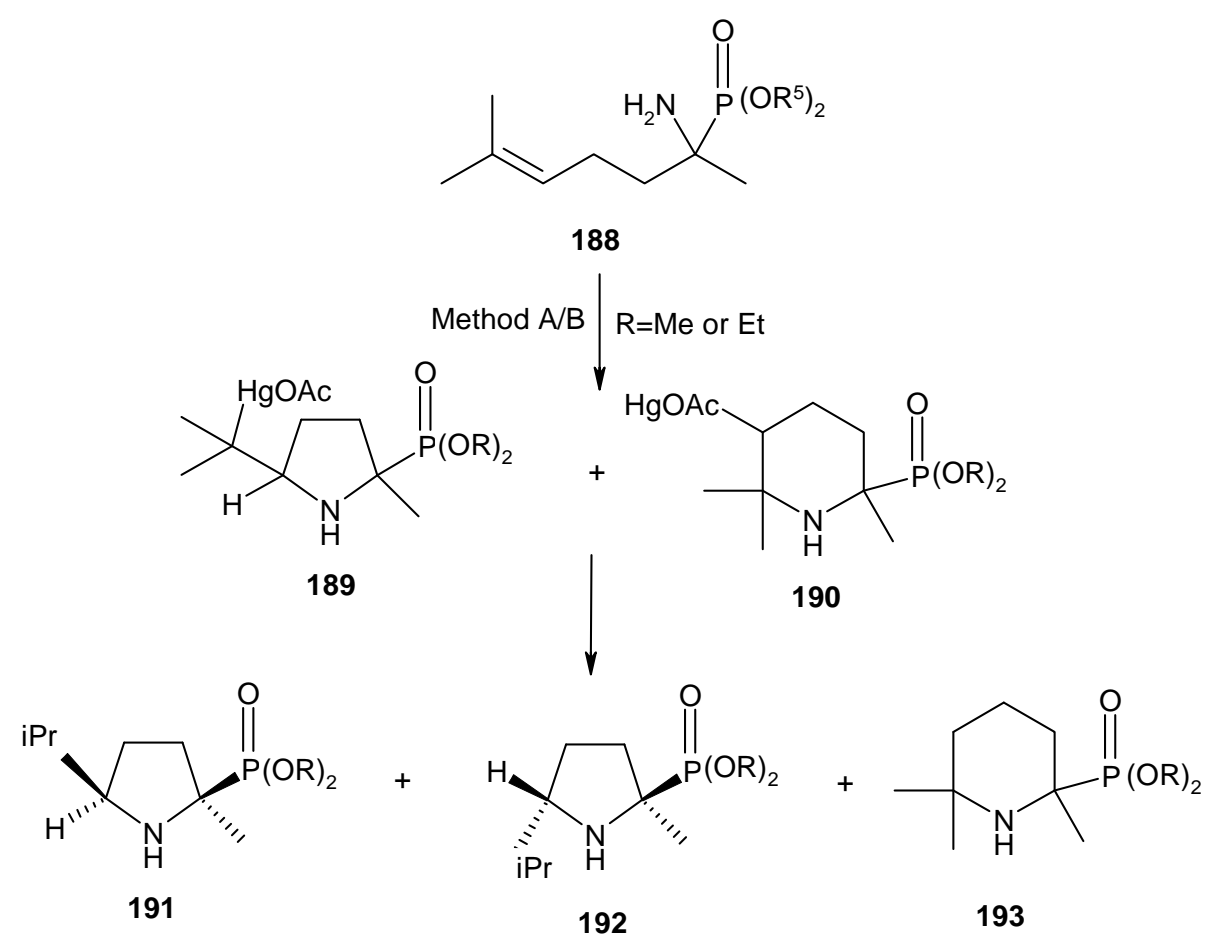

Method A: 1) $\mathrm{Hg}(\mathrm{OAc})_{2}$, acetone, 2) $\mathrm{NaBH}_{4}, \mathrm{CH}_{2} \mathrm{Cl}_{2}$

Method B: 1) $\mathrm{Hg}(\mathrm{OAc})_{2}$, THF/water, 2) $\mathrm{NaHBH}_{4}$, THF/water

\section{Scheme 61}

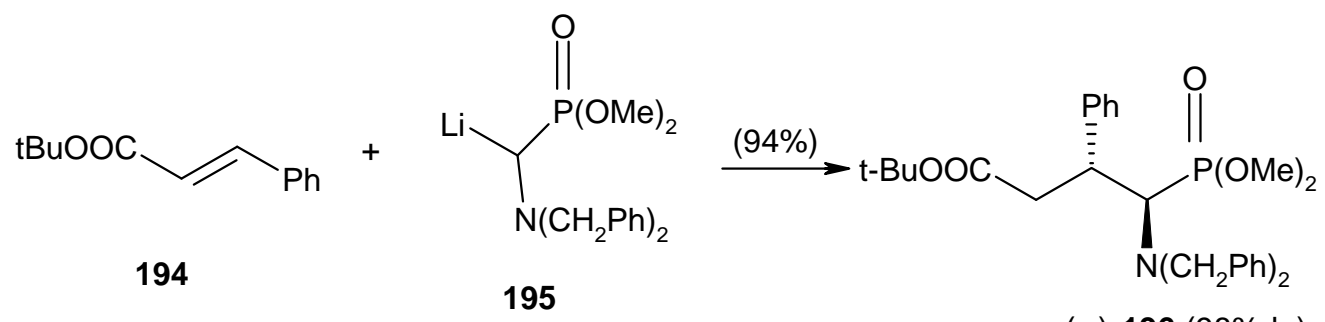

(+)-196 (98\%de)

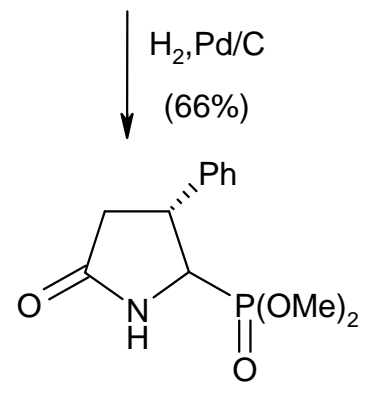

(+)197

\section{Scheme 62}


Cleavage of the sulfinyl group and hydrolysis of the acetal 198 gave the aminocarbonyl derivative, which cyclized to afford the iminophosphonates 199. Catalytic hydrogenation of 199 led to the cyclic $\alpha$-aminophosphonates $\mathbf{2 0 0}$ (Scheme 63). ${ }^{109}$

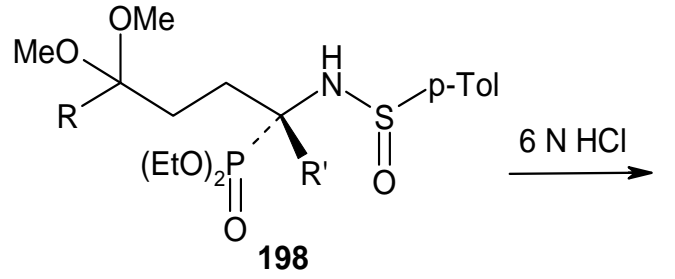

$\mathrm{R}=\mathrm{R}^{\prime}=\mathrm{H}, 93 \% \mathrm{de}$

$\mathrm{R}=\mathrm{R}^{\prime}=\mathrm{Me}, 86 \% \mathrm{de}$<smiles>[R]C1=NC([R])([P+](=O)O[Na])CC1</smiles>

$\mathrm{R}=\mathrm{R}^{\prime}=\mathrm{H}, 72 \%$

$\mathrm{R}=\mathrm{R}^{\prime}=\mathrm{Me}, 69 \%$<smiles>C1CC[PbH]C1</smiles>

(R)-, $\quad \mathrm{R}=\mathrm{R}^{\prime}=\mathrm{H}, 72 \%$

$(2 \mathrm{R}, 5 \mathrm{~S}), \quad \mathrm{R}=\mathrm{R}^{\prime}=\mathrm{Me}, 69 \%$

\section{Scheme 63}

Addition of three to eight equivalents of amine to the enamide 201 in methanol or toluene afforded the 5-phosphonylated-2-imidazolidinones $\mathbf{2 0 2}$ which could be isolated in moderate yield $17-49 \%$ (Scheme 64). ${ }^{110}$

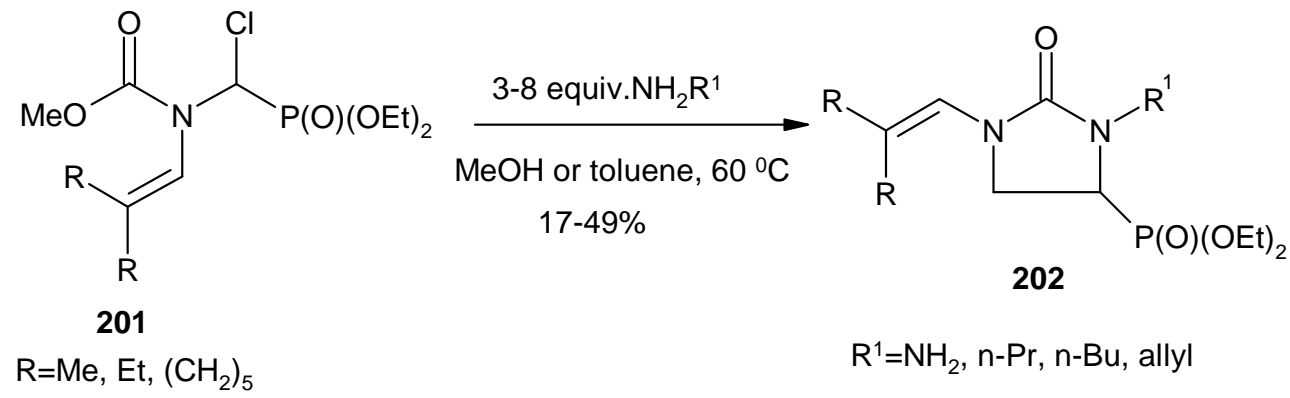

\section{Scheme 64}

Reaction of phosphoserinate $(R)$-203 with benzaldehyde, followed by reduction with sodium cyanoborohydride in acetic acid, afforded the N-benzyl $\alpha$-amino-phosphonate $(R)-204$ in 76\% yield. Treatment of $(R)-\mathbf{2 0 4}$ with thionyl chloride and subsequent oxidation with sodium periodate in the presence of ruthenium chloride gave the sulfonamide $(R)-\mathbf{2 0 5}$ in 70\% yield (Scheme 65). ${ }^{111}$ 
<smiles>CCO[P+](=O)[C@@H](N)CO</smiles>

$(R)-203$<smiles>C=[PH](OC)[C@H](CO)[C@H](CO)Nc1ccccc1</smiles>

$76 \%$

$(R)-204$

$$
\begin{aligned}
& \text { 1) } \mathrm{SOCl}_{2} / \text { imidazole } \\
& \mathrm{Et}_{3} \mathrm{~N}, \mathrm{CH}_{2} \mathrm{Cl}_{2} \\
& \text { 2) } \mathrm{RuCl}_{3}, \mathrm{NalO}_{4}
\end{aligned}
$$<smiles>CCOC(=O)C1COS(=O)(=O)N1Nc1ccccc1</smiles>

$(R)-205$

\section{Scheme 65}

The $\alpha$-aminophosphonate $\mathbf{2 0 6}$ was submitted to a hydrogenolysis-reductive amination, resulting in the polyhydroxylated piperidinylphosphonate 207 (Scheme 66). ${ }^{112}$

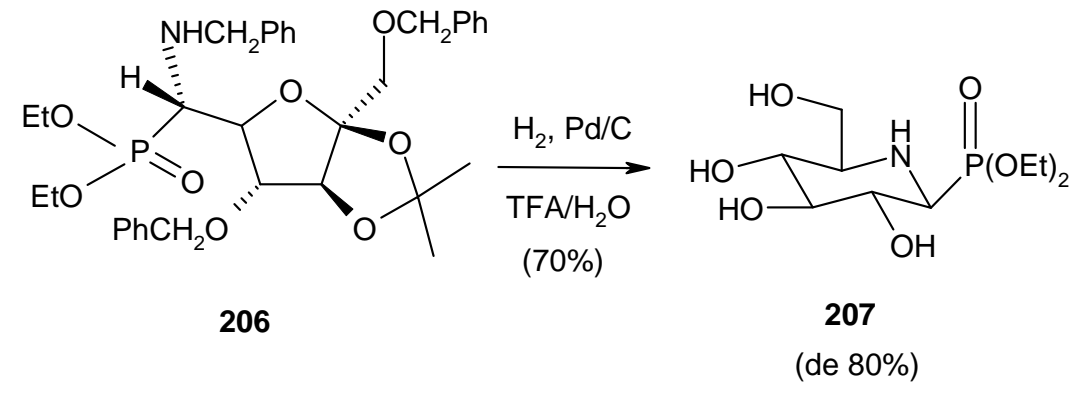

\section{Scheme 66}

Davis et al. ${ }^{109}$ described the stereoselective synthesis of piperidin-2-yl-phosphonates $210 \mathbf{a}, \mathbf{b}$. Cleavage of the sulfinyl group and acidic hydrolysis of the ketal in 208a,b gave an aminocarbonyl derivative, which underwent cyclization to afford the iminophosphonates 209a,b. Finally, catalytic hydrogenation of 209a,b led to the cyclic $\alpha$-aminophosphonates $(2 R, 6 S)-210 a$ and $(2 R, 6 R)-\mathbf{2 1 0 b}$, respectively (Scheme 67).

Ring closing metathesis (RCM) of $\alpha$-aminophosphonates, bearing two terminal alkene chains, was a convenient strategy to synthesize heterocyclic $\alpha$-aminophosphonates. Osipov et al. succeeded in the synthesis of the cyclic aminophosphonates 213. ${ }^{113,114}$ Allylation of the nitrogen 
atom of $\alpha, \beta$-unsaturated $\alpha$-aminophosphonates 211 gave rise to the 1,7-dienes 212 which can be ring closed to the 3-piperidines $\mathbf{2 1 3}$ using a Ru catalyst (Scheme 68).

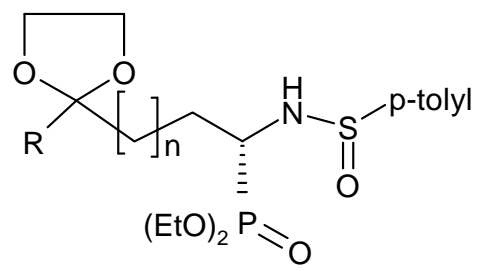

208a; $\mathrm{R}=\mathrm{Me}, 98 \%$ de

208b; R=Ph, $94 \%$ de

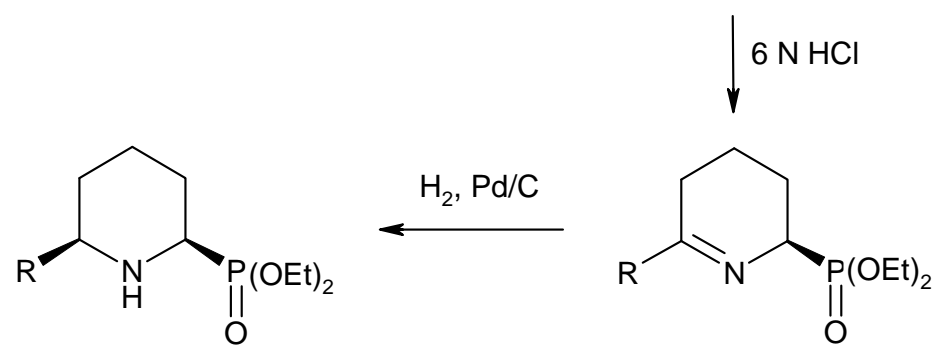

(2R,6S)-210a; $\mathrm{R}=\mathrm{Me}$

$(2 R, 6 R)-210 b ; \mathrm{R}=\mathrm{Ph}$

209a,b

\section{Scheme 67}

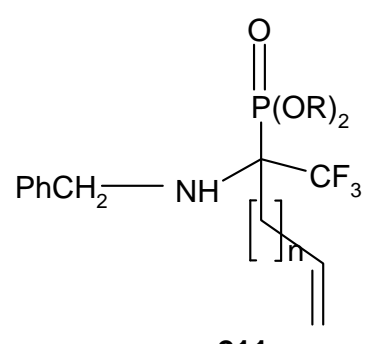

211
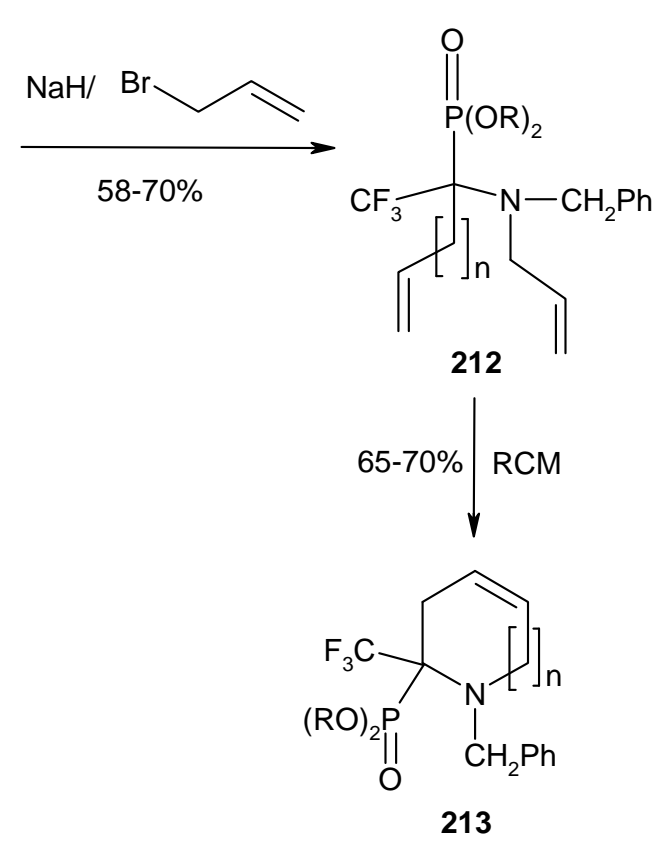

$\mathrm{R}=\mathrm{Me}, \mathrm{Et}, \mathrm{n}=1,2$

\section{Scheme 68}


Conversion of $\alpha$-amino-(2-alkynylphenyl)methylphosphonate 214 to 2,3-disubstituted-1,2dihydroisoquinolin-1-yl phosphonate 215 was performed through 6-endo-cyclization utilizing silver triflate as catalyst (Scheme 69). ${ }^{115}$

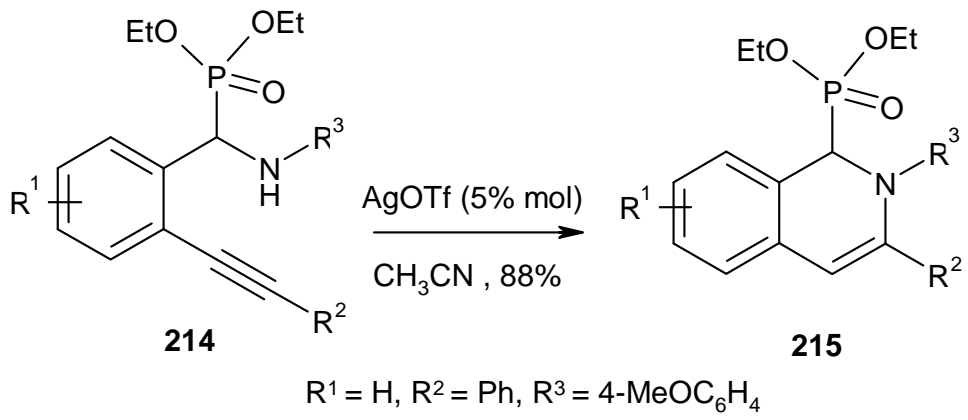

\section{Scheme 69}

\subsection{Ring closure of acyclic $\beta$-aminophosphonates}

The hydrolysis of diethyl ester 216 led in a one-pot procedure to the pure $\beta$-amino- phosphonic acid 217 (yield: 47\%). Cyclization of 217 by boiling in aqueous sodium hydroxide forms within 5 minutes the disodium salt, which gave $86 \%$ of pure aziridine 218 after passage through an ion exchange column (Scheme 70). ${ }^{116,117}$

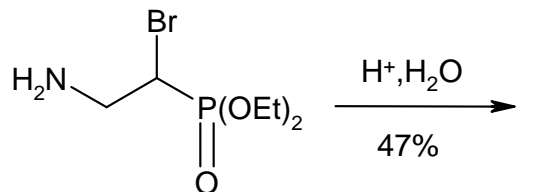

216<smiles>NCC(Br)[Po](=O)O</smiles>

217
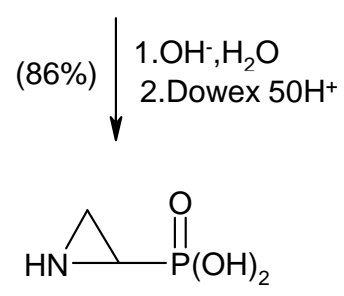

218

\section{Scheme 70}

Treatment of the mesylated $\beta$-aminophosphonate 219 with $\mathrm{K}_{2} \mathrm{CO}_{3}$ in DMF resulted in the formation of the $N$-protected aziridines 220 in high yields and purity (>99\%) (Scheme 71$){ }^{118}$

The diastereoisomers of $\beta$-aminophosphonates 221 and 222 were cyclized using $\mathrm{NaH}$, resulting in the diastereoisomers 223 (76\%) and 224 (75\%), respectively, which were subjected 
to hydrolysis conditions (TFA-MeOH) or MeMgBr to give the corresponding acids 225 and 226, respectively (Scheme 72). ${ }^{73,119-120}$<smiles>[R]N[C@H](c1ccc(OC)cc1)[C@H](OC)P(=O)=O</smiles>

$(1 \mathrm{R}, 2 \mathrm{R})-\mathbf{2 1 9}$

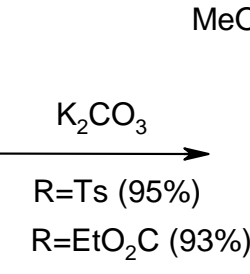

$\mathrm{R}=\mathrm{EtO}_{2} \mathrm{C}(93 \%)$<smiles>[R]N1[C@H]([R](=O)OC)[C@H]1c1ccc(C)cc1</smiles>

(2S,3R)-220

\section{Scheme 71}<smiles>CCO[P+](=O)[C@@](C)(Cl)[C@H](NS(=O)[GeH2][O-])c1ccccc1</smiles>

221<smiles>[13NH2][V]</smiles><smiles>CCO[Pb](=O)N1C([Po])[C@H]1c1ccccc1</smiles>

(Ss,2S,3R)-223 (76\%)<smiles>[3H]C(O)(F)C(=O)OC</smiles>

225

$85 \%$<smiles></smiles>

222
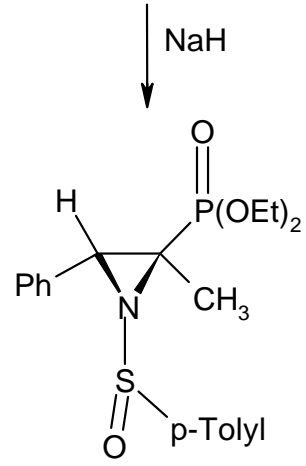

(Ss,2R,3R)-224 (75\%)

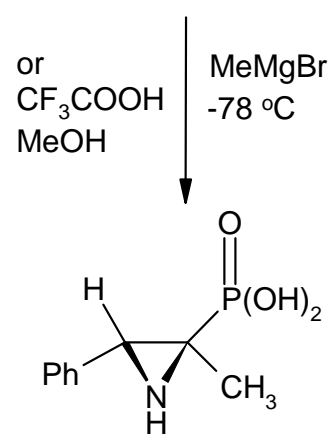

226

$82 \%$

Scheme 72 


\subsection{Ring closure of acyclic $\boldsymbol{\gamma}$-aminophosphonates}

Ring closure of the mesylates 227 in refluxing toluene-water mixture in the presence of $\mathrm{K}_{2} \mathrm{CO}_{3}$ produced azetidinyl-2-phosphonates (228), which were hydrolyzed into the corresponding azetidinyl-2-phosphonic acids (229) (Scheme 73). ${ }^{121}$

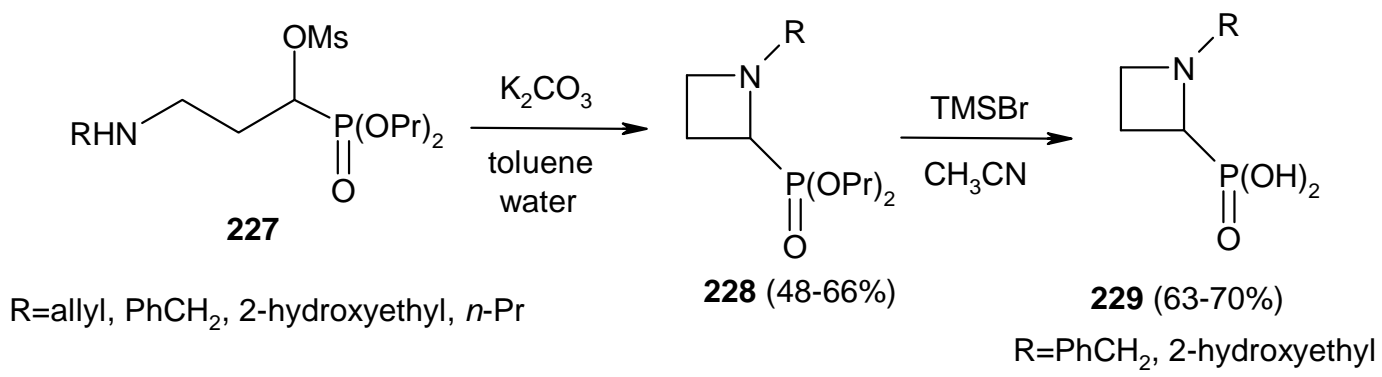

\section{Scheme 73}

\subsection{Ring closure of acyclic $\delta$-aminophosphonates}

Treatment of $\delta$-amino- $\beta$-ketophosphonates 230 with TFA, followed by reaction with (Boc) ${ }_{2} \mathrm{O}$, afforded the derivatives 231 in $80-90 \%$ yield. Reaction of 231 with $\mathrm{NaH}$ and 4-acetamidobenzenesulfonyl azide (4-ABSA) furnished the diazo derivatives 232 in excellent yield (8391\%), which, by treatment with $\mathrm{Rh}_{2}(\mathrm{OAc})_{4}$, led to the 3-oxo-pyrrolidine phosphonates 233. Removal of the 3-oxo group in $\mathbf{2 3 3}$ by treatment with $\mathrm{NaH}$, followed by the addition of diethyl chlorophosphonate, and subsequent hydrogenation of 234 provided the cyclic phosphonates 235 in good yield. Finally, cleavage of the Boc-protective group in $\mathbf{2 3 5}$ with TFA afforded the cis-5substituted pyrrolidine-2-phosphonates 236 in 68-86\% yield (Scheme 74). ${ }^{81,122-123}$ 

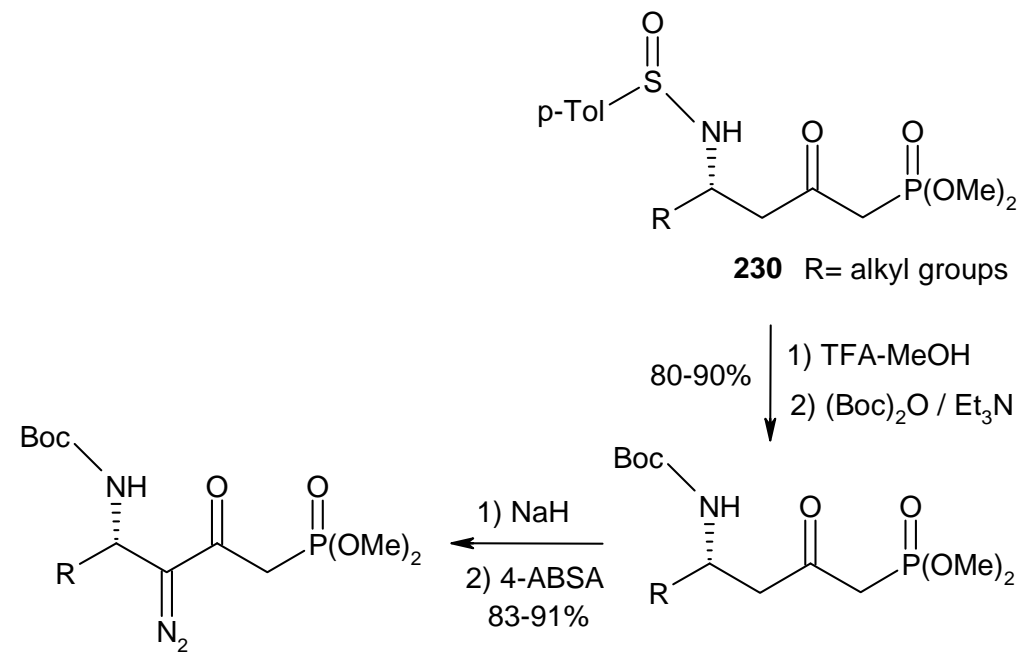

$$
\text { 80-90\% } \begin{aligned}
& \text { 1) TFA-MeOH } \\
& \text { 2) (Boc) })_{2} \mathrm{O} / \mathrm{Et}_{3} \mathrm{~N}
\end{aligned}
$$<smiles>[R]C(CC(=O)C[P+](C)=O)NC(=O)OCc1ccccc1</smiles>

232

231

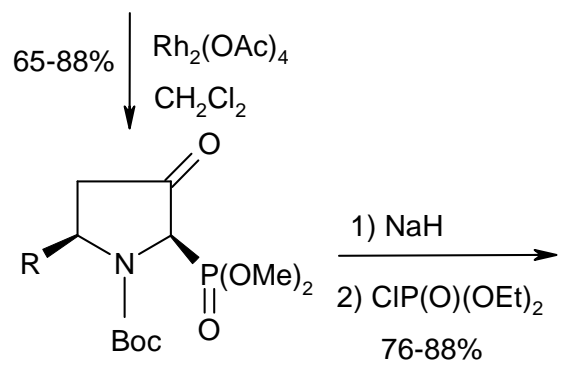

233
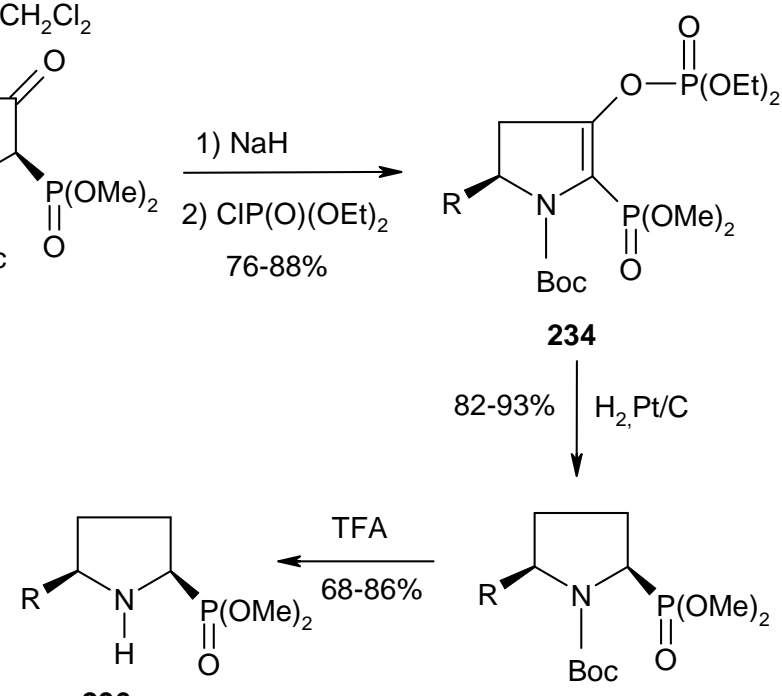

236

235

\section{Scheme 74}

\subsection{Ring closure of acyclic $\alpha$-hydroxyphosphonates}

Phosphonylated 2-imidazolidinone 239 was prepared from phosphonylated aldehyde 237 and urea 238 (Scheme 75). ${ }^{124,125}$ 


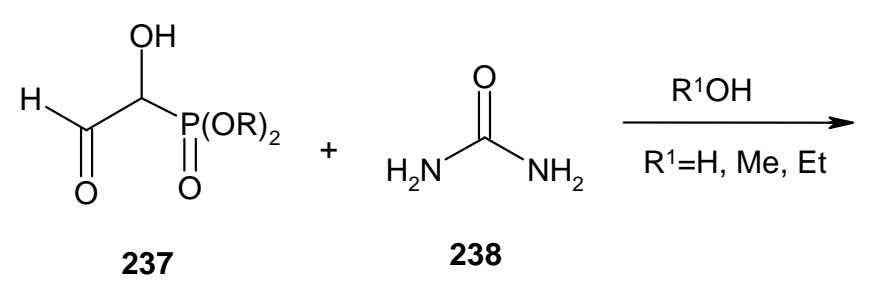<smiles>[R]O[Pb]C1NC(=O)N[C@@H]1O</smiles>

239

\section{Scheme 75}

\subsection{Ring closure of isothiocyanatomethylphosphonates}

The lithium derivative of diethyl isothiocyanatomethylphosphonate (240) was reacted with aldehyde to afford a mixture of cis- and trans-(2-thioxo)oxazolidine-4-yl)phosphonate (241) which were separated by column chromatography (Scheme 76$).{ }^{126,127}$

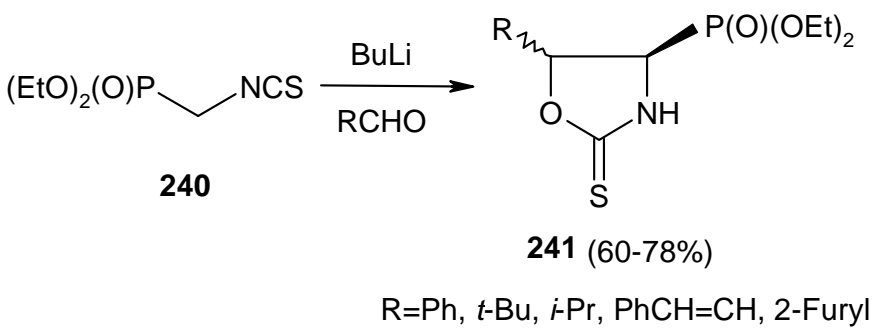

\section{Scheme 76}

Blaszczyk et al. ${ }^{128}$ demonstrated that the diastereoselective addition of diethyl isothiocyanatomethylphosphonate (240) to various $N$-protected imines $\mathbf{2 4 2}$ afforded the cyclic thioxoimidazolidinylphosphonates 245 (Scheme 77).

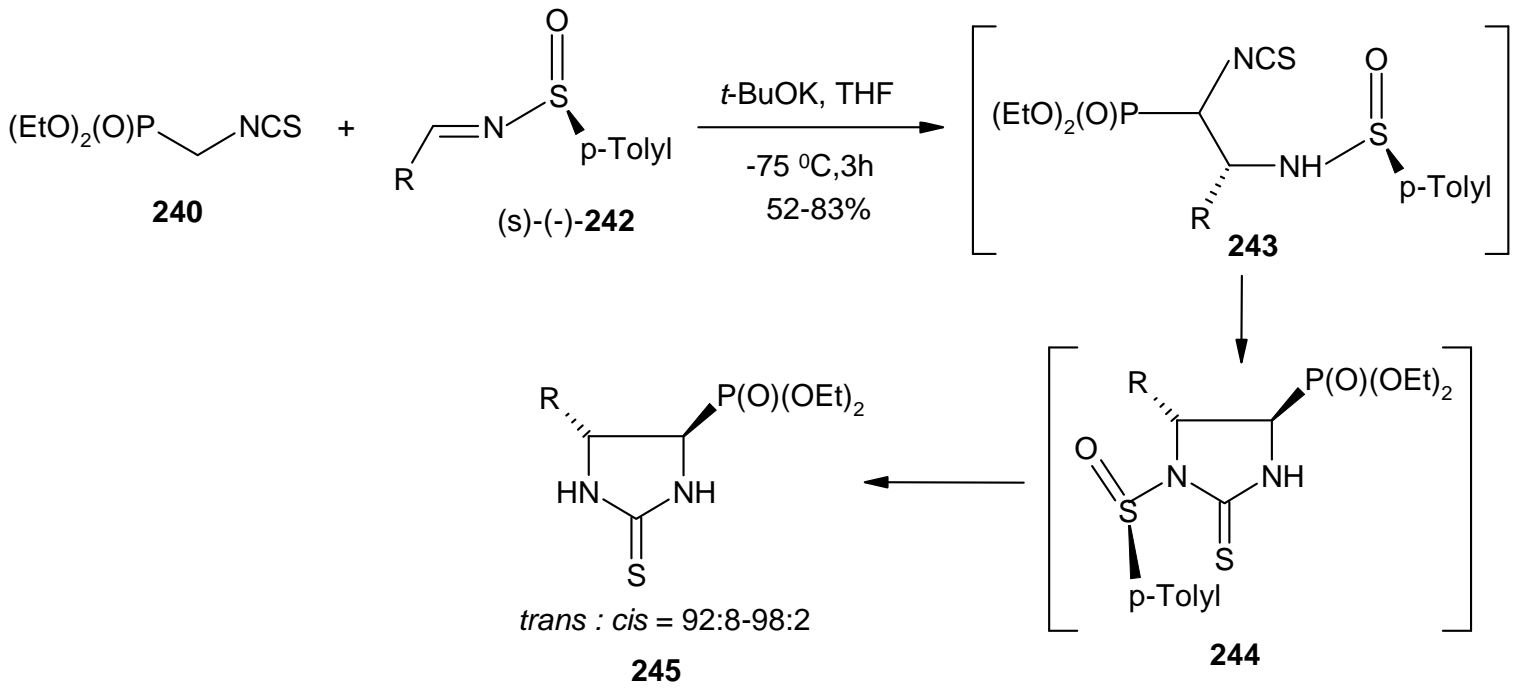

\section{Scheme 77}




\subsection{Miscellaneous}

3.14.1. Photocyclization. The antibacterial phosphonoaziridine 247 and a salt of $2 \mathrm{H}$-aziridine 248 were prepared via photocyclization reactions. ${ }^{116}$ Thus, vinylphosphonate $\mathbf{2 4 6}$ was treated with ethyl azidoacetate by irradiation with UV light (Scheme 78).

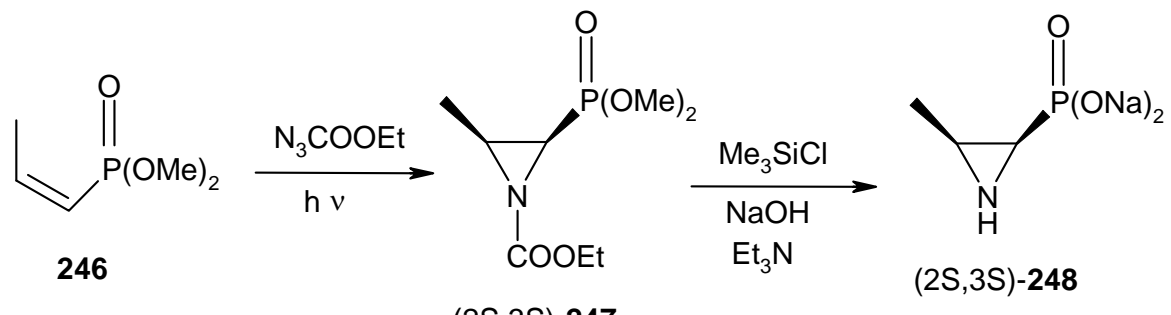

$(2 S, 3 S)-247$

\section{Scheme 78}

3.14.2. Reaction of azirine phosphonate with Grignard reagent. Reaction of $2 H$-azirine phosphonate 249 with ethyl magnesium bromide in $\mathrm{THF}$ at $-78{ }^{\circ} \mathrm{C}$ led exclusively to the formation of diethyl trans-3-ethyl-3-methylaziridin-2-ylphosphonate (250) (Scheme 79). ${ }^{129}$

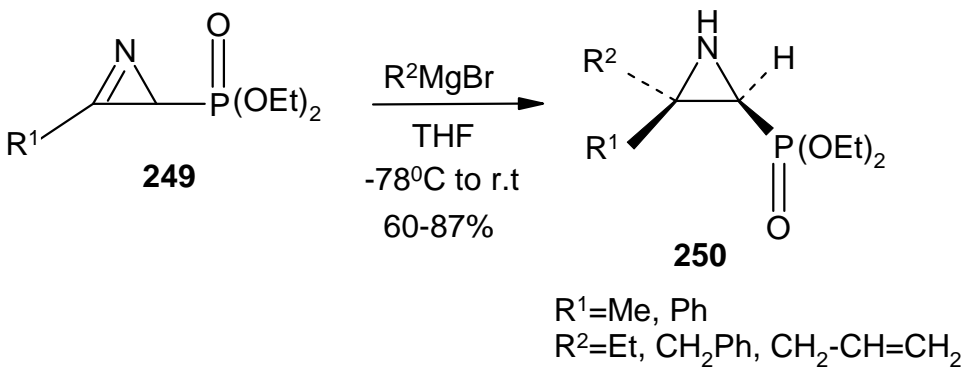

\section{Scheme 79}

3.14.3. Phosphonylation of lactams. Lactam 251 was phosphonylated with triethyl phosphite in the presence of phosphorus oxychloride. The 1,1-diphosphonoazetidine 252 was obtained in only low yields (28\%) (Scheme 80$){ }^{130}$

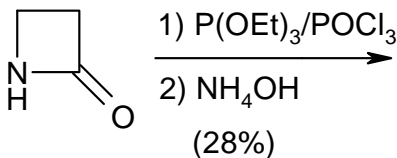

251<smiles>CCO[PH](=O)C1([PH](=O)OCC)CCN1</smiles>

252

Scheme 80 
3.14.4. Hydrolysis of an acetal. The acetal 254 was hydrolyzed in an acidic medium, and the resulting mixture was treated with several triphenyl phosphite reagents in hydrochloric acid to give diastereomeric mixtures of the N-protected diphenyl pyrrolidinephosphonates 255 (Scheme $81)^{131,132}$

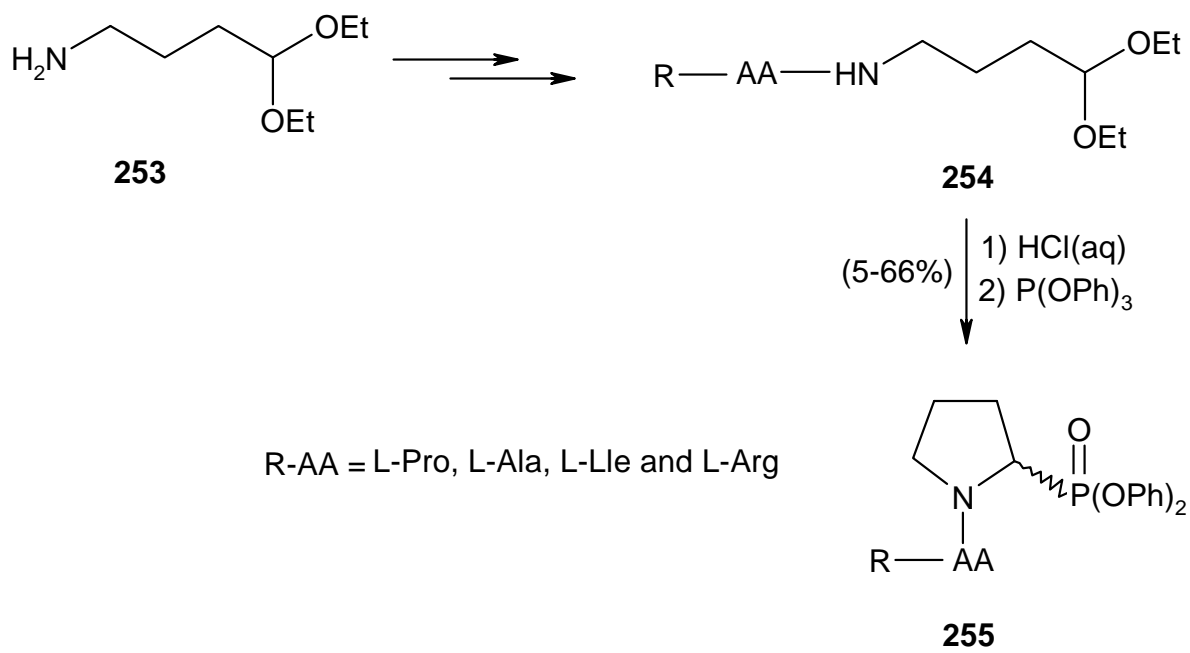

\section{Scheme 81}

3.14.5. Cycloaddition to phosphorylated nitrile ylide. Diethyl isocyanomethylphosphonate 256 can be used immediately in a cycloaddition reaction with methacrylonitrile 257 and $\mathrm{Cu}_{2} \mathrm{O}$ as a catalyst, producing the pyrroline $\mathbf{2 5 8}$ in $83 \%$ yield (Scheme 82 ). ${ }^{133}$

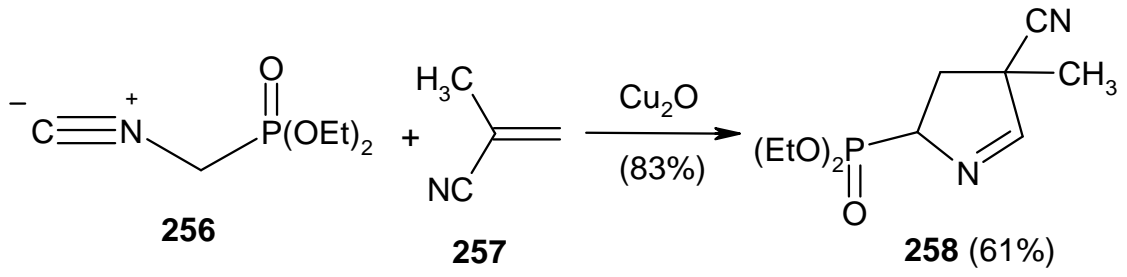

\section{Scheme 82}

3.14.6. Cycloaddition to phosphorylated nitrone. 1,3-Dipolar cycloaddition of nitrone 259 was first examined with terminal alkenes in toluene at $60{ }^{\circ} \mathrm{C}$. Cis- and trans-diastereomeric isoxazolidines $\mathbf{2 6 0}$ and 261 were obtained in the ratio 90:10 in yields 23-73\% (Scheme 83). ${ }^{134}$ 


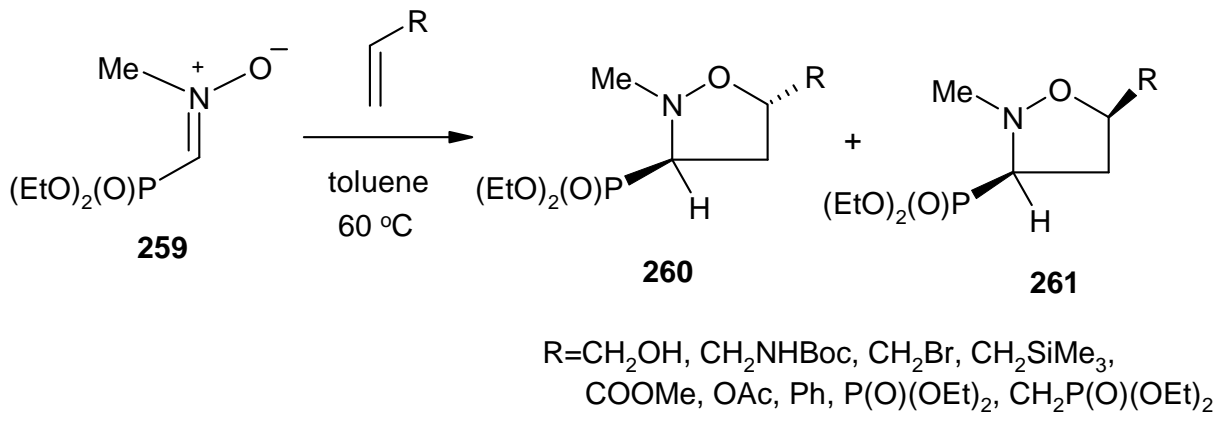

\section{Scheme 83}

4. Type C: Cyclic a-Aminophosphonic Acid Derivatives Containing the Phosphorus and Nitrogen as Ring Heteroatoms

\subsection{Addition of phosphorus reagents to acyclic imines}

4.1.1. addition of phosphites to acyclic imines (Pudovik reaction). In the reaction of $N$-(benzylidene)-2-aminoethanol (262) with diethyl/ethane/bis( $\beta$-chloroethyl)chlorophosphite in $\mathrm{CHCl}_{3}$, 2-( $\beta$-chloroethoxy)/ethoxy-2-oxo-3-phenyl-1,4,2-oxazaphosphorines (266) were obtained in good yields as diastereomers $\mathbf{A}$ and $\mathbf{B}$ (Scheme 84). ${ }^{135,136}$

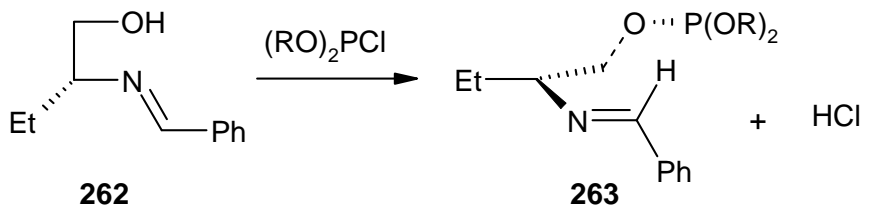

$(\mathrm{RO})_{2}=(\mathrm{EtO})_{2},\left(\mathrm{ClCH}_{2} \mathrm{CH}_{2} \mathrm{O}\right)_{2}, \mathrm{OCH}_{2} \mathrm{CH}_{2} \mathrm{O}$
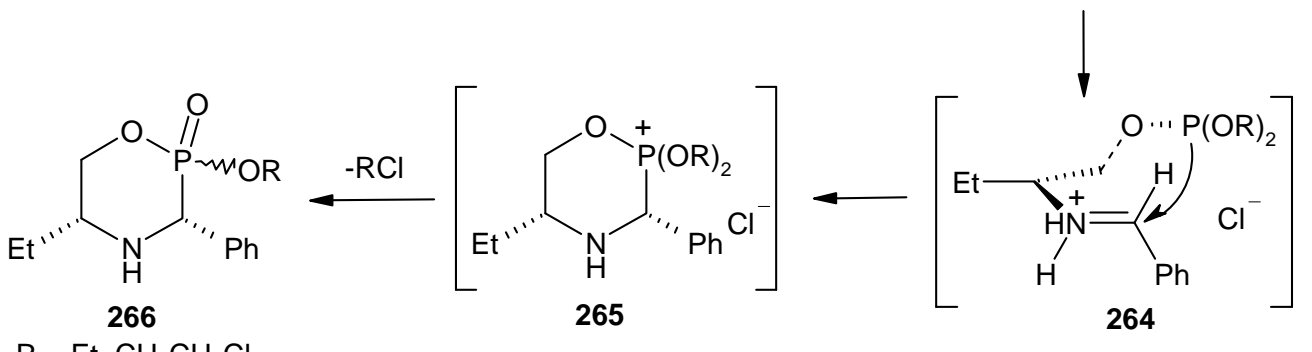

$\mathrm{R}=\mathrm{Et}, \mathrm{CH}_{2} \mathrm{CH}_{2} \mathrm{Cl}$

$$
\begin{aligned}
& \text { A } 2 R, 3 R, 5 R \\
& \text { B } 2 S, 3 R, 5 R
\end{aligned}
$$

\section{Scheme 84}

Reaction of 2-(N-benzylidene)aminophenol (267) with diethyl chlorophosphite carried out in the absence of an external $\mathrm{HCl}$ acceptor resulted in the formation of two diastereomers of 2-(2'alkoxy)-2-oxo-3-phenyl-1,4,2-benzoxazaphosphorinanes (271) (Scheme 85). ${ }^{137}$ 


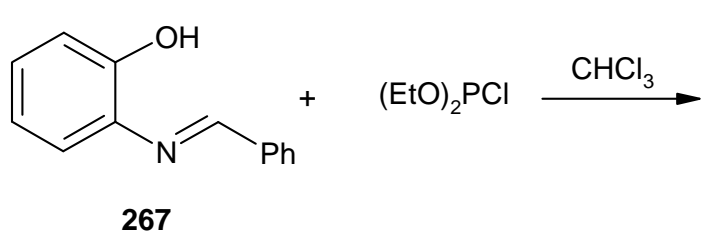<smiles>CCO[P@]1(=O)Oc2ccccc2NC1c1ccccc1</smiles>

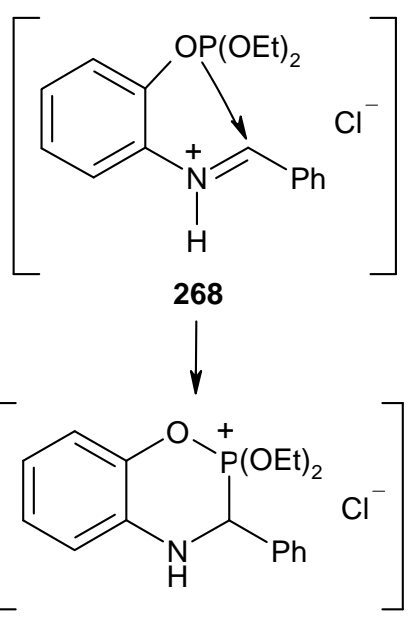

271

270

\section{Scheme 85}

The Pudovik reaction of hydrazone 272 using diethyl phosphite in boiling THF containing a catalytic amount of sodium hydride produced a cyclic $\alpha$-aminophosphonate ester 274 as only one isomer (Scheme 86). ${ }^{138}$

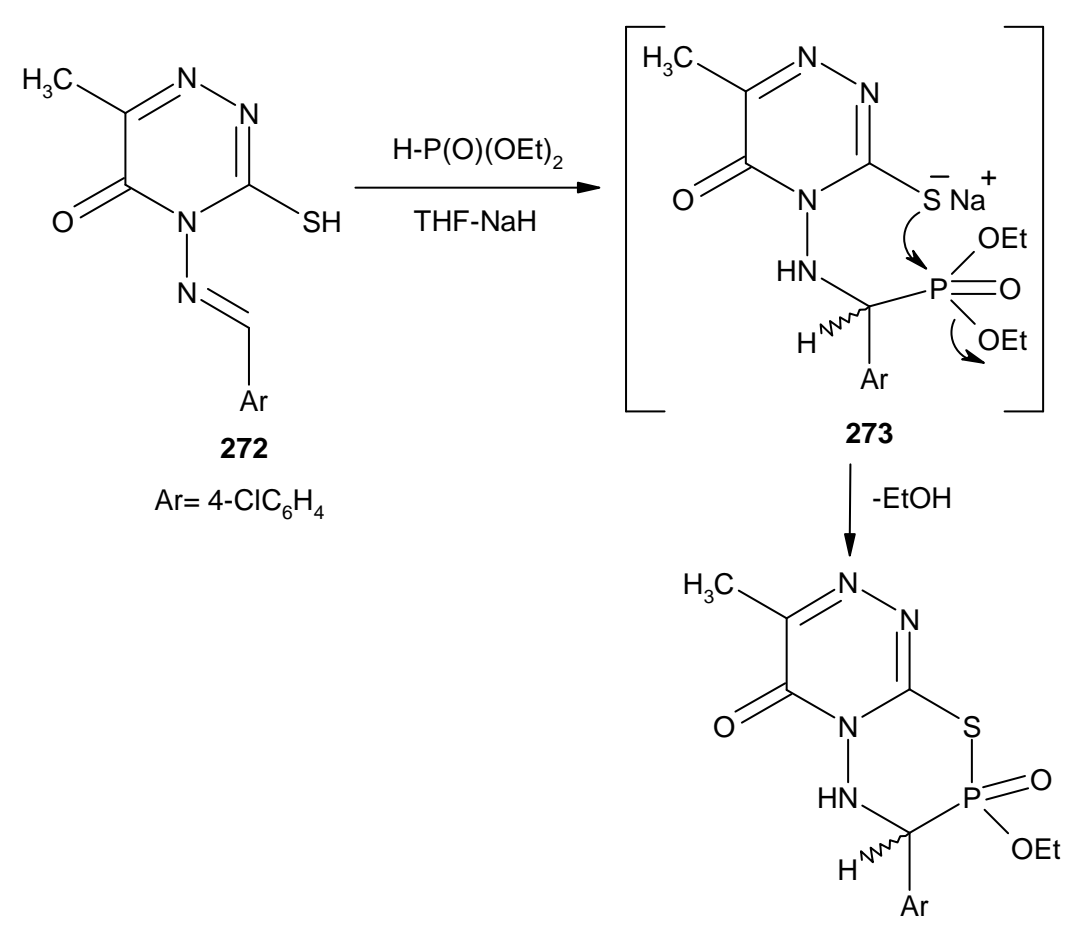

274

\section{Scheme 86}


Heterocyclization of bis-thiosemicarbazone 275 with diethyl phosphite at $80{ }^{\circ} \mathrm{C}$ in the presence of $\mathrm{BF}_{3} \cdot \mathrm{Et}_{2} \mathrm{O}$ at $80{ }^{\circ} \mathrm{C}$ for 10 hours, afforded an interesting type of phosphorus heterocycle, namely bis-[3-(4'-biphenyl)-4-[2-ethoxy-6-phenylamino-2-oxo-3,4-dihydro-2H1,4,5,2-thiadiazaphosphinin-3-yl]-1H-pyrazol-1-yl phosphine oxide (277) (Scheme 87). The proposed mechanism for formation of $\mathbf{2 7 7}$ may occur via addition of the phosphorus atom of

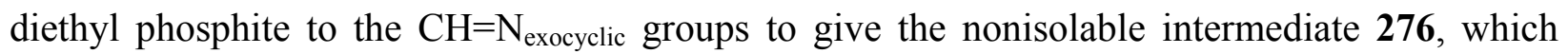
underwent cyclization by nucleophilic attack of $\mathrm{SH}$ groups at the phosphonate to eliminate two molecules of ethanol (Scheme 87). ${ }^{139}$
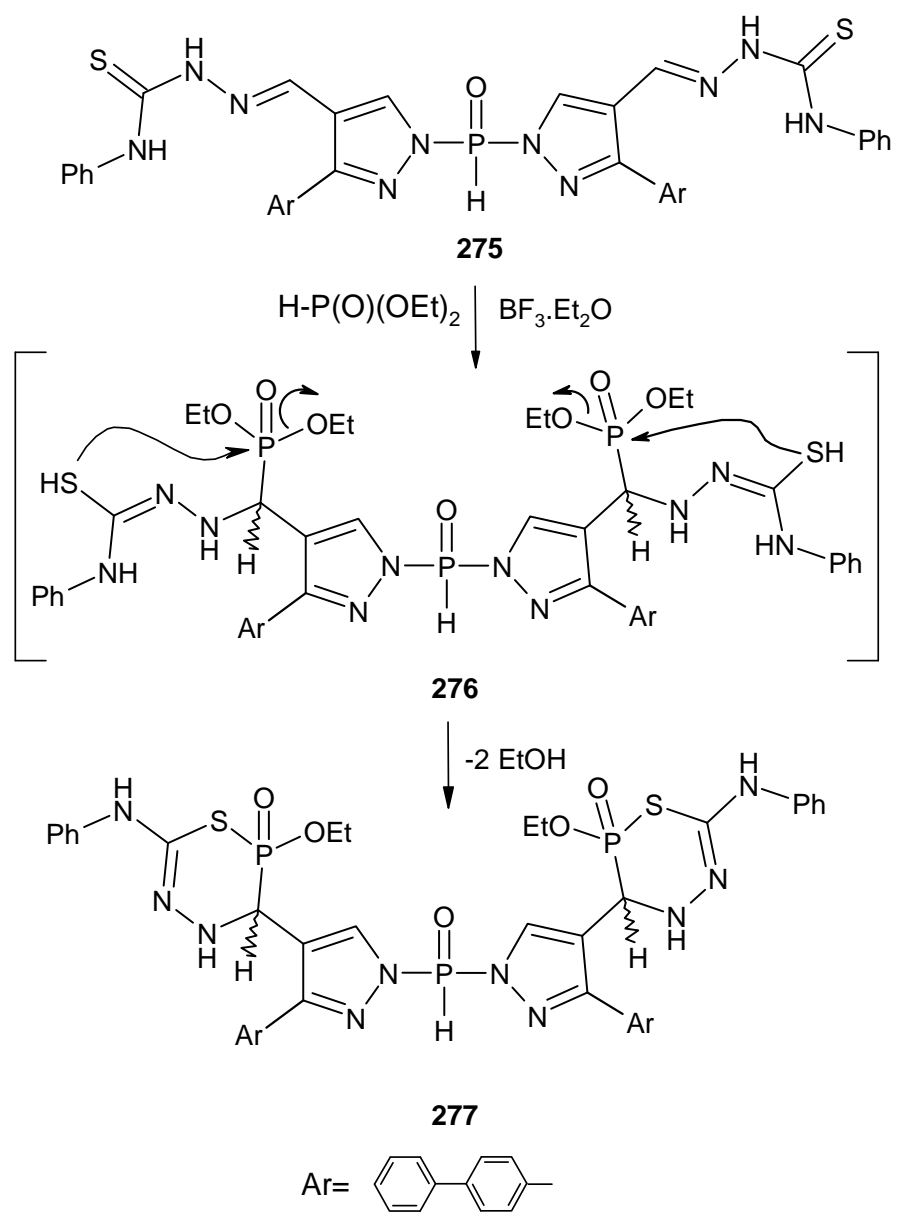

\section{Scheme 87}

Addition of diethyl phosphite to the azomethine bond of the hydrazone 278 required heating at $80-100{ }^{\circ} \mathrm{C}$ with triethylamine as a catalyst and gave 3-(4-amino-5-ethoxy-3,5-dioxo-1,2,4,3,5triazadiphosphinan-6-yl)-4H-chromen-4-one (280). Most likely, the addition led to intermediate 279 (not isolated), which underwent intramolecular cyclization via elimination of ethanol affording compound $\mathbf{2 8 0}$ (Scheme 88). ${ }^{140}$ 
<smiles>NNP(=O)([18O])NN=Cc1coc2ccccc2c1=O</smiles><smiles>CCOP(=O)(NN)NC(CC)(c1coc2ccccc2c1=O)P(=O)(OCC)OCC</smiles>

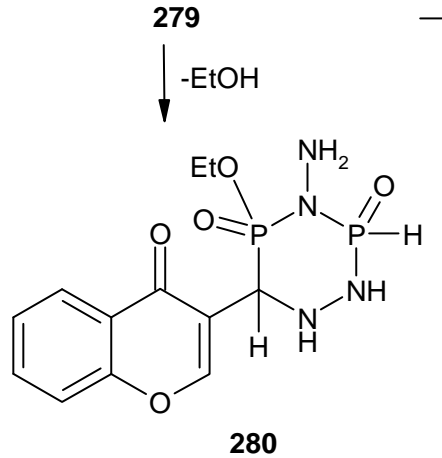

\section{Scheme 88}

4.1.2. Addition of isocyanatophosphite to acyclic imines. The phosphorylation pathway for (trichloroethanylidene)-N-methylamine $\mathbf{2 8 1}$ was determined by the nature of the phosphorus reagent. Thus, its reaction with trivalent phosphorus isocyanates as 1,3-dipole gave cyclic $C$ phosphorylated iminophosphoranes $\mathbf{2 8 2}$ which transformed into $\alpha$-aminophosphonate $\mathbf{2 8 3}$ as a result of imide-amide rearrangement (Scheme 89). ${ }^{141}$

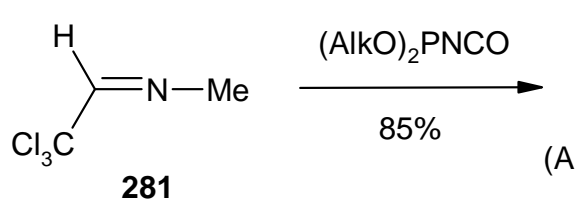<smiles>CN1C(=O)N=[PH](O[GeH3])C1C(Cl)(Cl)Cl</smiles><smiles>CN1C(=O)N([AlH2])P(=O)(O[AlH2])C1(C=C=[Ru+2])C(Cl)(Cl)Cl</smiles>

283

\section{Scheme 89}


Reaction of $N$-acetyl compound $\mathbf{2 8 4}$ with dimethyl isocyanatophosphite in benzene at 20-60 ${ }^{\circ} \mathrm{C}$, gave the cycloadduct $\mathbf{2 8 5}$ which underwent imide-amide rearrangement leading to stereoisomeric diazaphospholanes 286 and 287 (Scheme 90). ${ }^{142}$
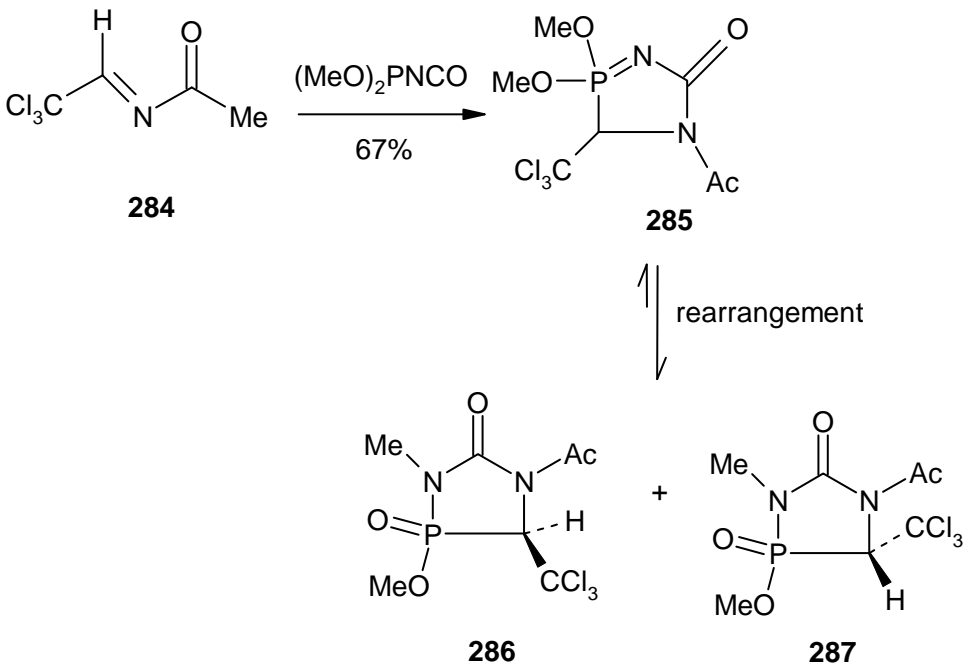

\section{Scheme 90}

At the same time, dimethyl isocyanatophosphite reacted with imine $\mathbf{2 8 8}$ as a 1,3 dipole giving the diazaphospholanes 290 (Scheme 91). ${ }^{142}$

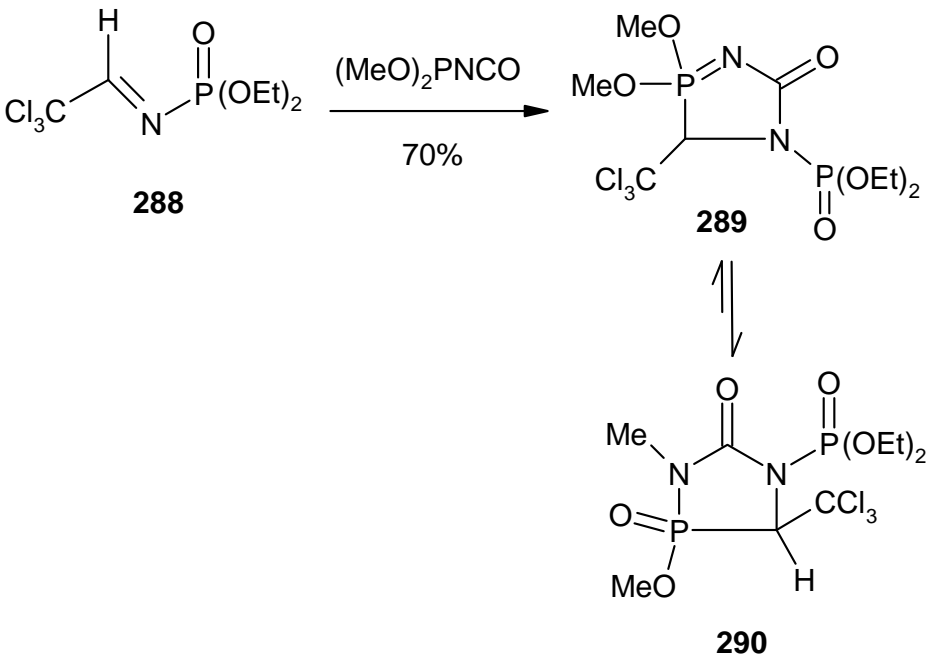

\section{Scheme 91}

\subsection{Multicomponent reactions}

4.2.1. Reaction of carbonyl and aminoalcohols with phosphites (Kabachnik-Fields reaction). The Mannich type reaction between 2-aminoethanol and formaldehyde in an aqueous 
solution of phosphorous acid did not result in the expected ([(2hydroxyethyl)imine]bis(methylphosphonic) acid 291 but in [(2-hydroxy-2-oxido-1,4,2oxazaphosphinan-4-yl)methyl]phosphonic acid (292) as a product of an intramolecular condensation (Scheme 92). ${ }^{143}$<smiles></smiles>

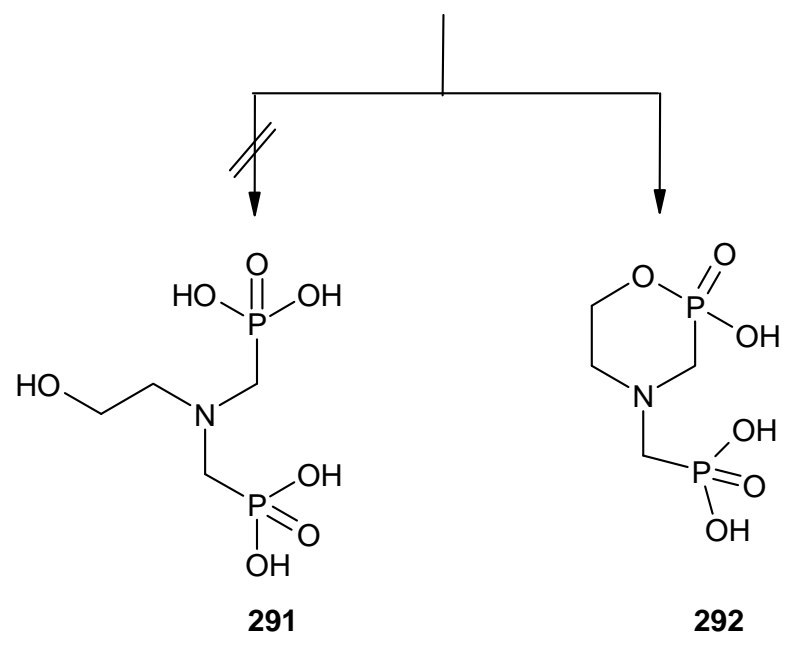

\section{Scheme 92}

2-Aminophenol was allowed to react with alkyl dichlorophosphinite and various substituted ketones or benzaldehyde in anhydrous tetrahydrofuran containing a small amount of potassium carbonate to give 2-alkoxy-2-oxo-1,4,2-oxazaphosphinane 294 in good yield. The reaction was carried out using a one pot procedure (Scheme 93 ). ${ }^{144-147}$

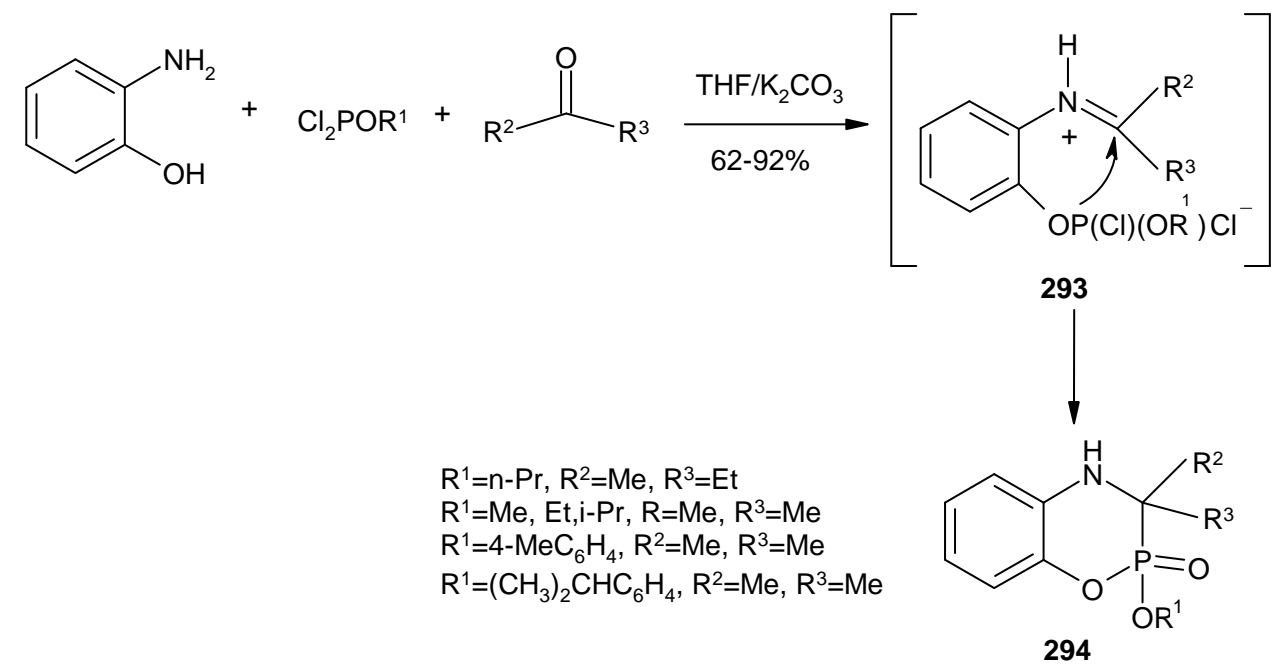

\section{Scheme 93}


Similarly, when the starting material 2-amino-3-hydroxy-1,4-naphthoquinone (295) reacted with phenyl phosphorodichloridite and ketone or aromatic aldehyde, 2-alkoxy/aryloxy-3,4dihydro-2H-naphtho[2,3-e][1,4,2] oxazaphosphinane-5,10-dione 2-oxides (296) were obtained in $55-82 \%$ yields (Scheme 94$).{ }^{148,149}$

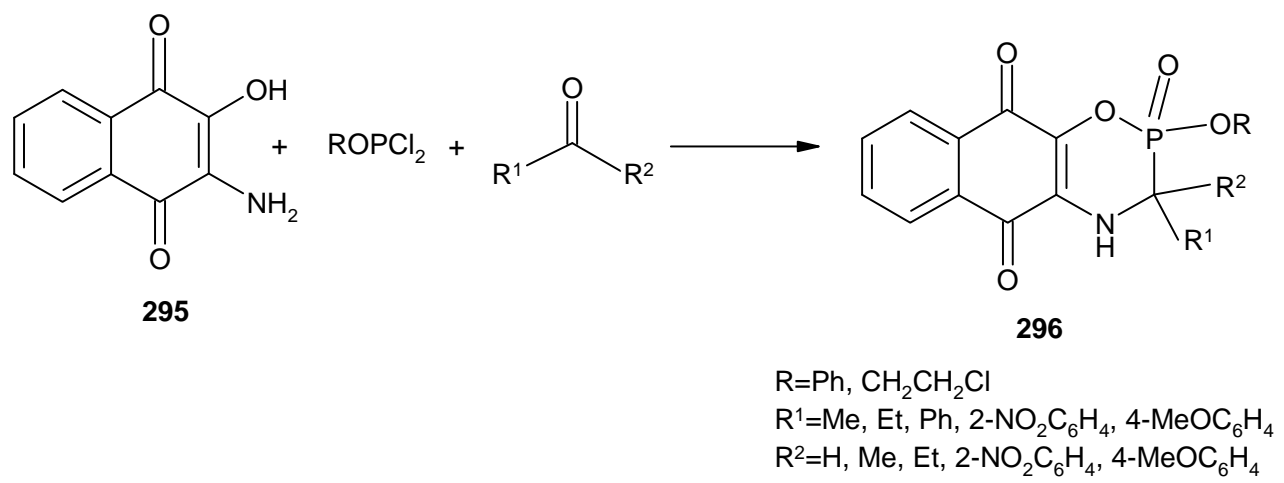

\section{Scheme 94}

The Kabachnik-Fields reaction using 3,4-diamino-6-methyl-1,2,4-triazin-5(4H)-one (297), acetaldehyde and diethyl phosphite in THF in the presence of sodium hydride as a catalyst led to only one isomer of 1,2,4-triazino[4,3-b][1,2,4,5]triazaphosphinine derivative 299 (Scheme 95). ${ }^{138}$<smiles>Cc1nnc(N)n(N)c1=O</smiles>

297

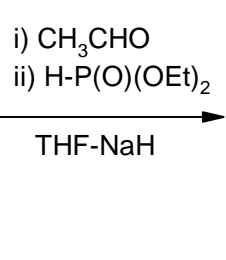

i) $\mathrm{CH}_{3} \mathrm{CHO}$

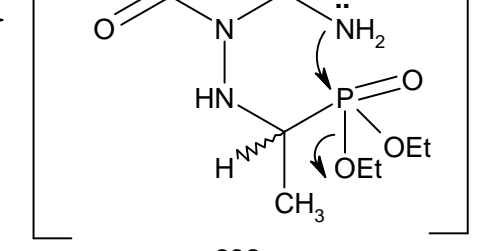

298<smiles>CCO[C@H](C)OCCO</smiles>

\section{Scheme 95}


The one-pot Kabachnik-Fields reaction of compound 300, acetaldehyde and diethyl phosphite in THF containing sodium hydride as a catalyst produced one isomer of $[1,2,4]$ triazino[3,2-c][1,2,4,5]triazaphosphinine $\mathbf{3 0 3}$, via the nonisolable intermediate $\mathbf{3 0 2}$, which spontaneously was cyclized through $\mathrm{N}-2$ of the triazine ring and not the exocyclic $\mathrm{N}$-amino, with elimination of a molecule of ethanol (Scheme 96). ${ }^{138}$<smiles>CC=NN=c1[nH]nc(C)c(=O)n1N</smiles><smiles>CCOP1(=O)[C@H](C)NN=C2N(N)C(=O)C(C)=NN21</smiles>

303

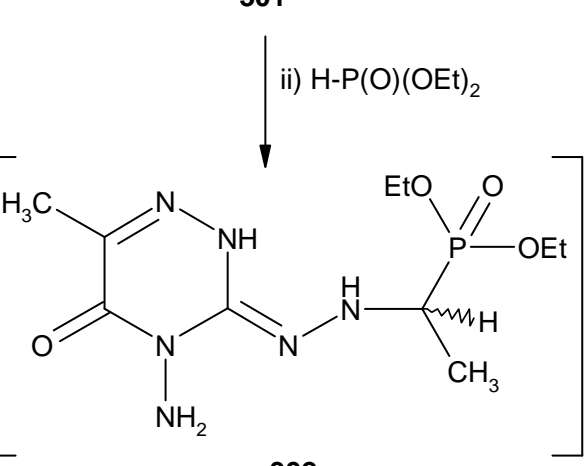

302

\section{Scheme 96}

Diethyl [[(3-hydroxypropyl)amino](aryl)methyl]phosphonate (304) and 1,4,2-oxazaphosphepane derivative $\mathbf{3 0 5}$ were prepared by the Kabachnik-Fields reaction, realizing a three component combination of 3-aminopropanol, $o$-tolualdehyde and diethyl phosphite in toluene (Scheme 97). ${ }^{150}$

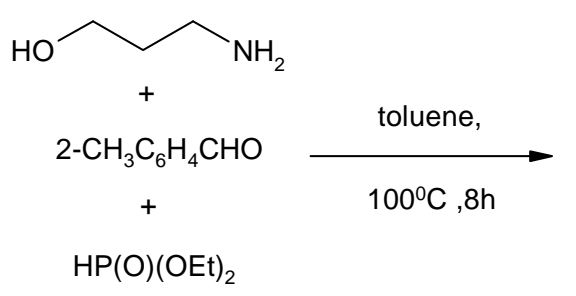

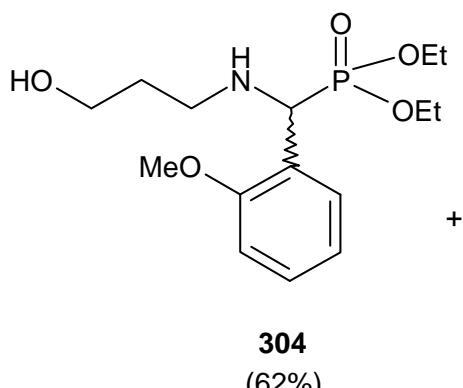

(62\%)

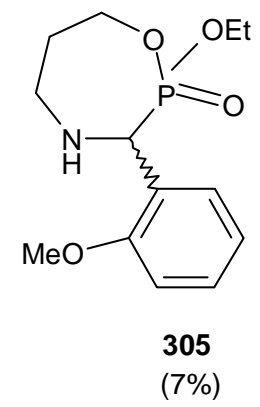

(7\%)

\section{Scheme 97}


The eight-membered 3,7-dihydroxy-3,7-dioxoperhydro-1,5,3,7-diazadiphosphocine-1,5diacetic acid (306) was obtained with a one step reaction of glycine, formaldehyde and hypophosphorous acid in acidic aqueous medium (Scheme 98). ${ }^{151}$

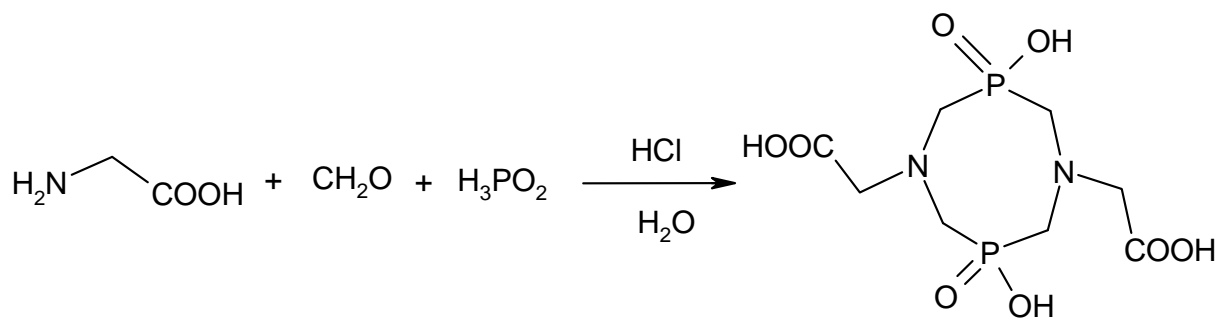

306

\section{Scheme 98}

4.2.2. Reaction of cyclopropanone acetal and 1,2-aminoalcohols with phosphites. Reaction of (2S)-phenylglycinol (307) with cyclopropanone acetal (308) and triethyl phosphite gave the spirophosphonates $\mathbf{3 0 9}$ and $\mathbf{3 1 0}$ in low yield and in diastereoisomeric ratio 89:11 (Scheme 99). ${ }^{152}$

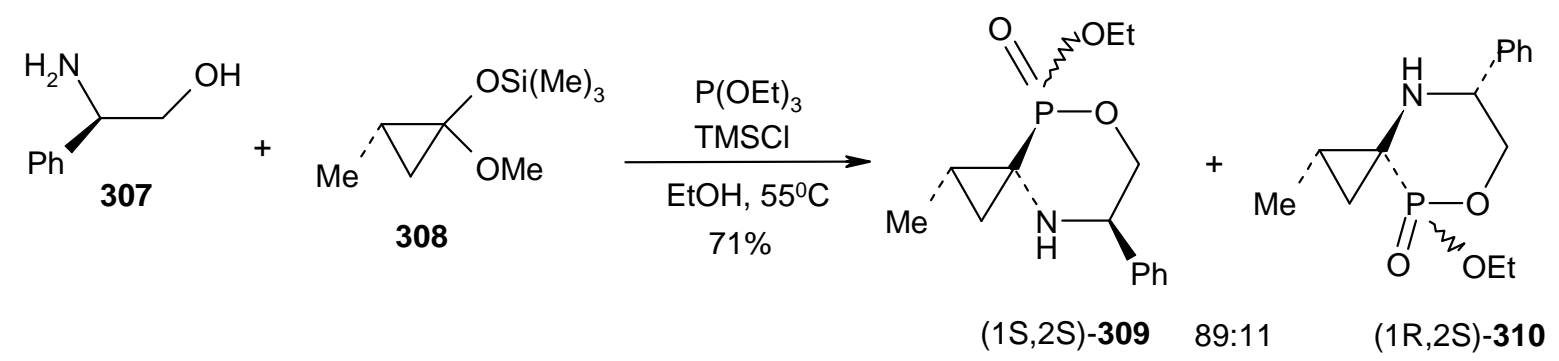

\section{Scheme 99}

\subsection{Ring closure of acyclic $\alpha$-aminophosphonates}

Fluorinated 1-methylaminoalkylphosphonates 311 reacted with $\mathrm{NH}_{3}$ to form heterocyclic salts 312, which underwent elimination of ammonia under heating to give the neutral 1,4,2diazaphospholines 313 (Scheme 100). ${ }^{153}$ 


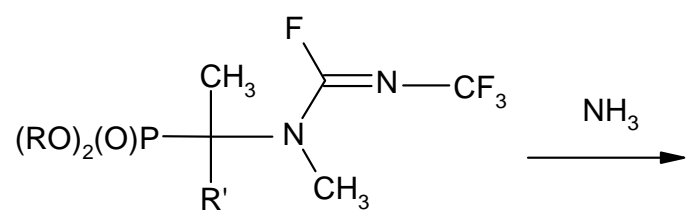

311

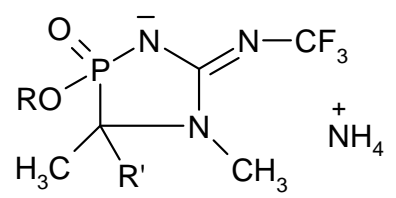

312

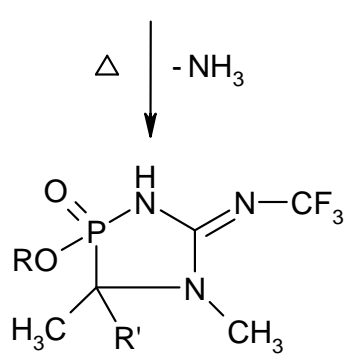

313

\section{Scheme 100}

Phosphorylated urea 316 was obtained as the result of addition of $\alpha$-aminoalkylphosphonates 314 to bis(chloromethyl)isocyanatophosphonate (315). Compound 316 can be cyclized in two ways: a) with elimination of phenol and formation of diazaphospholidine 317 , which under the action of phenol was converted into diazaphospholidine 318. and b) in the presence of a base, intramolecular alkylation of oxygen atoms of carbonyl fragment by chloromethyl group took place with the formation of 1,3,4-oxazaphosphol-2-ines 319 (Scheme 101). ${ }^{154}$

It was found that diphenyl ( $\alpha$-methylamino)benzyl phosphonate (320) readily underwent addition to different iso(thio)cyanates in the presence of a catalytic amount of triethylamine, yielding 1,3,4-diazaphospholidines 322a-e. The reaction involved intermediate formation of $N, N^{\prime}$-disubstituted (thio)ureas 321 which underwent fast cyclization by elimination of phenol. The labile exocyclic P-N bond of 322d,e was cleaved upon the action of phenol to give the final product diazaphospholidine 323 (Scheme 102). ${ }^{155-157}$

A highly diastereoselective synthetic procedure for the preparation of enantiopure $(2 S, 5 S)-4$ benzyl-2-alkoxy-2-oxo-5-phenyl-1,4,2-oxazaphosphinanes [(2S, 5S)-1] (326) from (S)-phenylglycinol (307) was achieved by its condensation with benzaldehyde followed by palladium catalyzed hydrogenation to give $N$-benzyl-(S)-phenylglycinol (324). The latter compound was condensed with formaldehyde (toluene solvent) and the resulting imminium salt was immediately treated with dialkyl phosphite to afford Mannich products $(S)$-325. Treatment of carbinol $(S)-325$ with KH in THF solution afforded cyclized products $\mathbf{3 2 6}$ in good yield (Scheme 103). ${ }^{158}$ Also, compound $\mathbf{3 0 7}$ was treated with trimethyl phosphite and formaldehyde to give $N$-(phosphonomethyl)oxazolidine 327. Treatment of $\mathbf{3 2 7}$ with phenyl magnesium bromide and in the presence of $\mathrm{TiCl}_{4}$ gave directly the expected $\mathbf{3 2 6}(\mathrm{R}=\mathrm{Me})$ but in low yield (Scheme 103). ${ }^{159}$ 


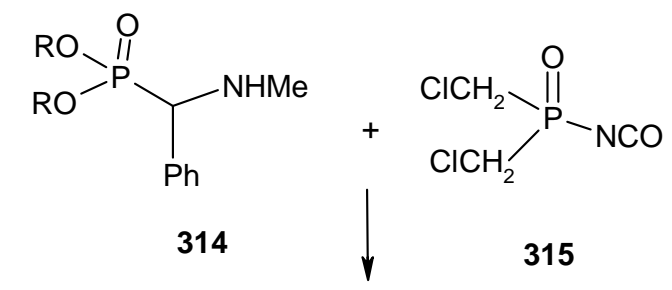<smiles>[R]OP([R])(=O)C(c1ccccc1)N(C)C(=O)NP(=O)(CCl)CCl</smiles>

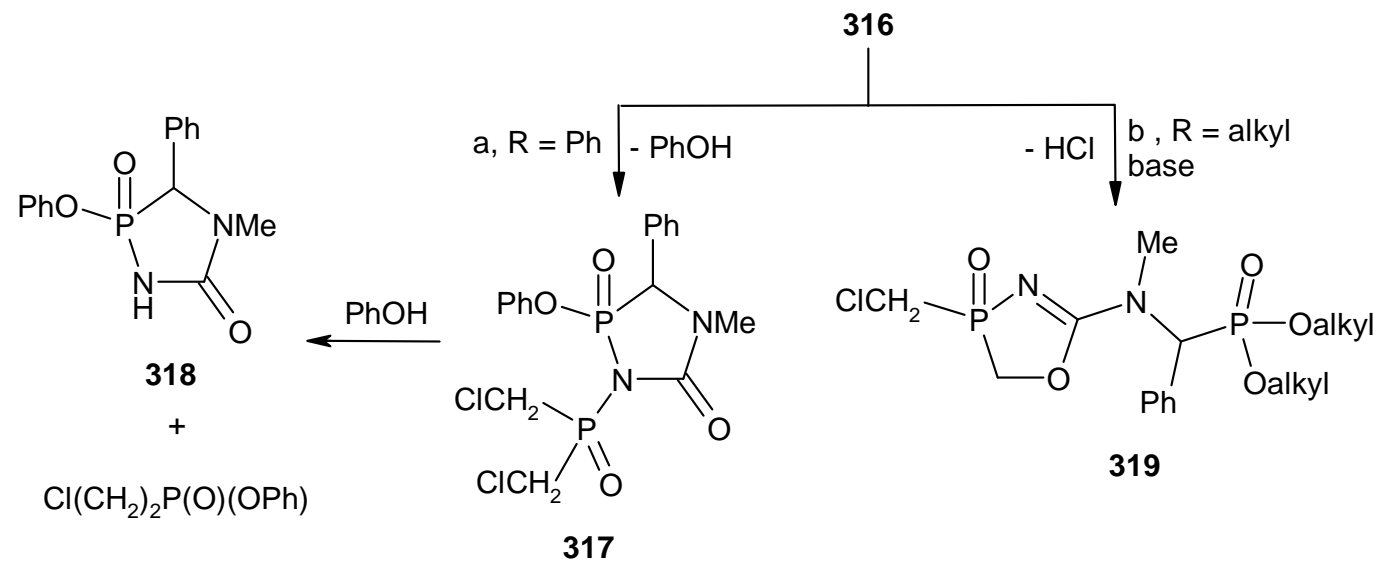

\section{Scheme 101}

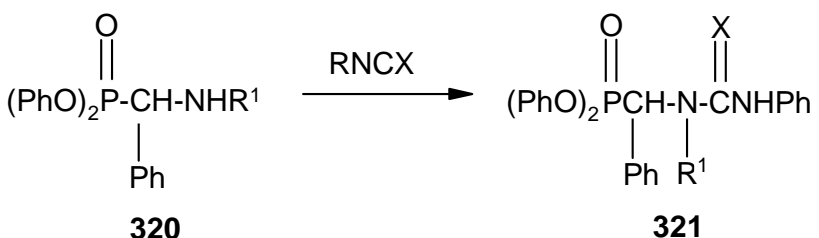

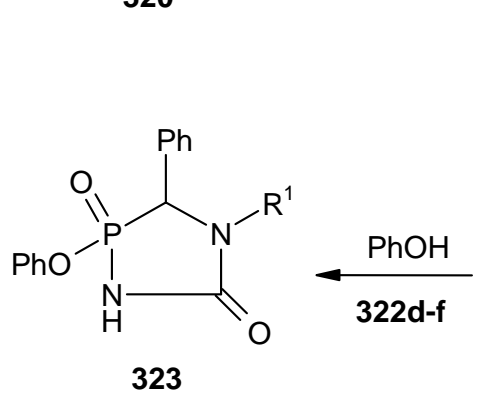

322a, $R=P h, R^{1}=M e, X=O$ 322b, $\mathrm{R}=\mathrm{Ph}, \mathrm{R}^{1}=\mathrm{Me}, \mathrm{X}=\mathrm{S}$

322d, $\mathrm{R}=\left(\mathrm{ClCH}_{2}\right)(\mathrm{PhO})(\mathrm{O}) \mathrm{P}, \mathrm{R}^{1}=\mathrm{Me}, \mathrm{X}=\mathrm{O}$

322c, $\mathrm{R}=(\mathrm{EtO})_{2}(\mathrm{O}) \mathrm{P}, \mathrm{R}^{1}=\mathrm{Me}, \mathrm{X}=\mathrm{S}$ 322e, $\mathrm{R}=\left(\mathrm{ClCH}_{2}\right)_{2}(\mathrm{O}) \mathrm{P}, \mathrm{R}^{1}=\mathrm{Me}, \mathrm{X}=\mathrm{O}$

322f, $\mathrm{R}=\left(\mathrm{ClCH}_{2}\right)(\mathrm{PhO})(\mathrm{O}) \mathrm{P}, \mathrm{R}^{1}=\mathrm{Ph}, \mathrm{X}=\mathrm{O}$

\section{Scheme 102}




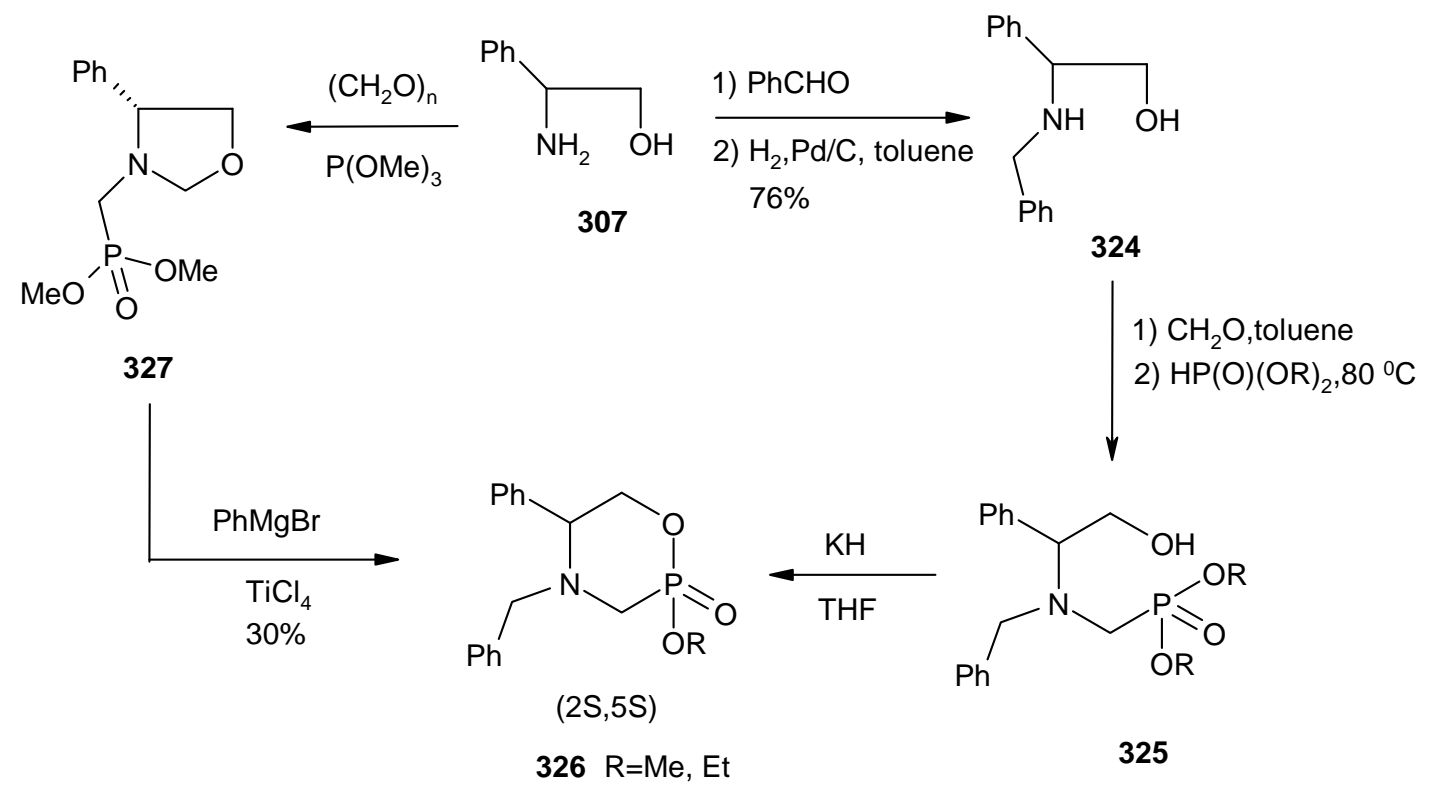

\section{Scheme 103}

Compounds 332, 328 and 329 when heated in absolute ethanol containing a catalytic amount of triethylamine afforded 3-[2-(2-chloroethoxy)-2-oxo-4-phenyl-1,4,2-oxazaphosphinan-3-yl]-6methyl-4-oxo-4H-chromen-4-one (331). Formation of compound 331 is assumed to take place via loss of one $\mathrm{HCl}$ molecule from 332, 328 and 329, followed by elimination of both water and aniline in the case of $\mathbf{3 2 8}$ and 329, respectively. Hydrogen bonding between $\mathrm{XH}$ and $\mathrm{NH}$ groups gives stability to systems $\mathbf{3 2 8}$ and 329, but destruction of this hydrogen bond, after removing a molecule of $\mathrm{HCl}$, may facilitate elimination of water and aniline (Scheme 104). ${ }^{33}$

5-Chloro-2-nitrobenzoyl chloride (333) was reacted with $\alpha$-aminophosphonate $\mathbf{3 3 4}$ to afford the nitroamide $\mathbf{3 3 5}$. Catalytic hydrogenation of $\mathbf{3 3 5}$ gave the cyclization precursor $\mathbf{3 3 6}$. Reacting a DMF solution of 336 with $\mathrm{NaH}$ followed by warming to $60{ }^{\circ} \mathrm{C}$ for a few hours, affording 4alkyl-7-chloro-2-ethoxy-2,3-dihydro-2-oxido-1H-1,4,2-benzodiazaphosphepin-5 (4H)-ones (337) (Scheme 105). ${ }^{160}$

\subsection{Miscellaneous}

4.4.1. Reaction of dialkyl/diphenyl phosphite with hydroxyl alkyl carbamate. 3-Ethyl-2hydroxy-2-oxo-1,4,2-oxazaphosphorinane (339) was obtained by treating various phosphonic acids diesters with hydroxyl alkyl carbamate mixtures 338. During the first stage of the reaction at $135{ }^{\circ} \mathrm{C}$, transesterification occurred to give urethane phosphonates. In the second stage of the reaction at $170{ }^{\circ} \mathrm{C}$, thermal decomposition of urethane phosphonate led to selective isolation of (339) in low yield (Scheme 106). ${ }^{161-163}$ 


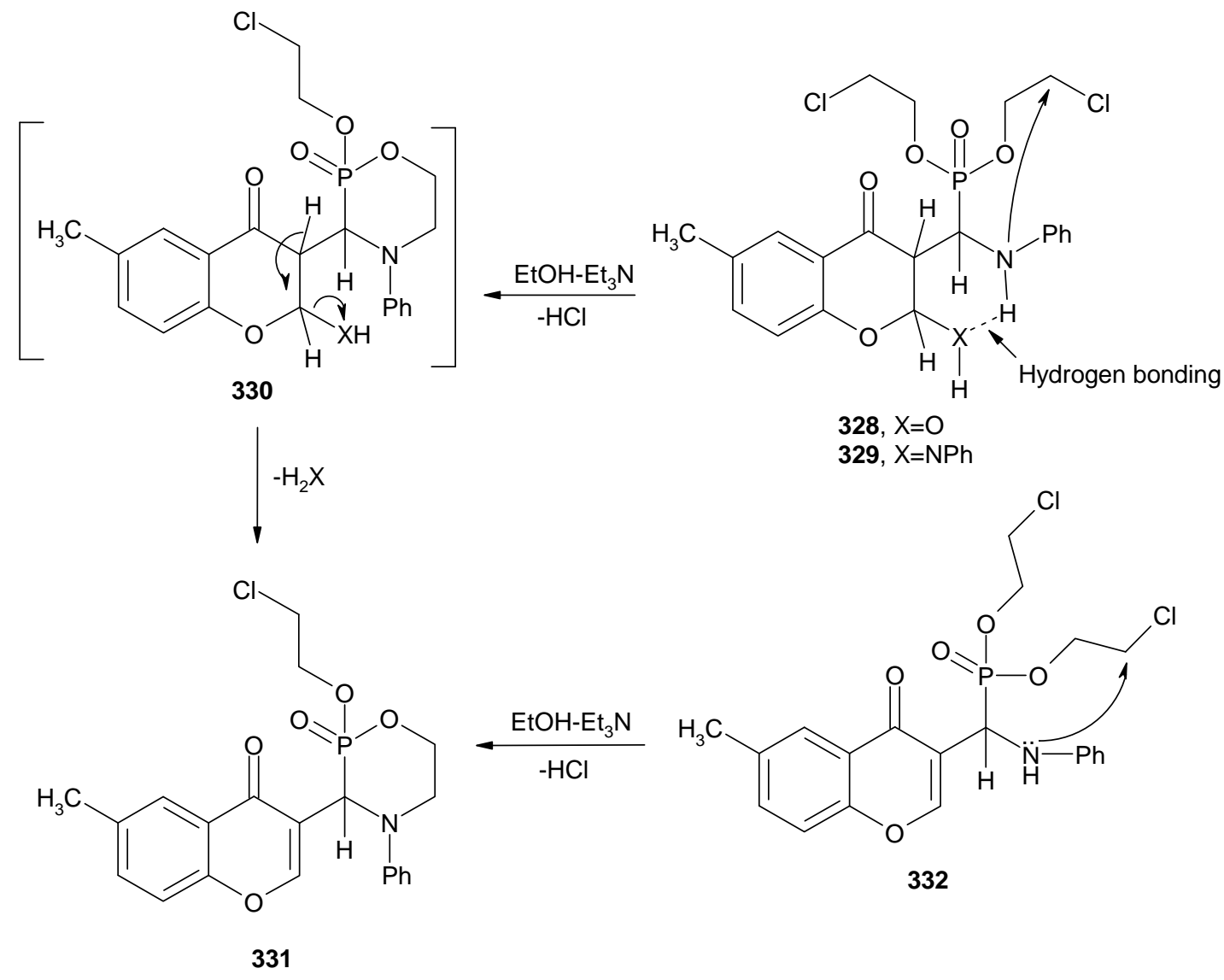

\section{Scheme 104}

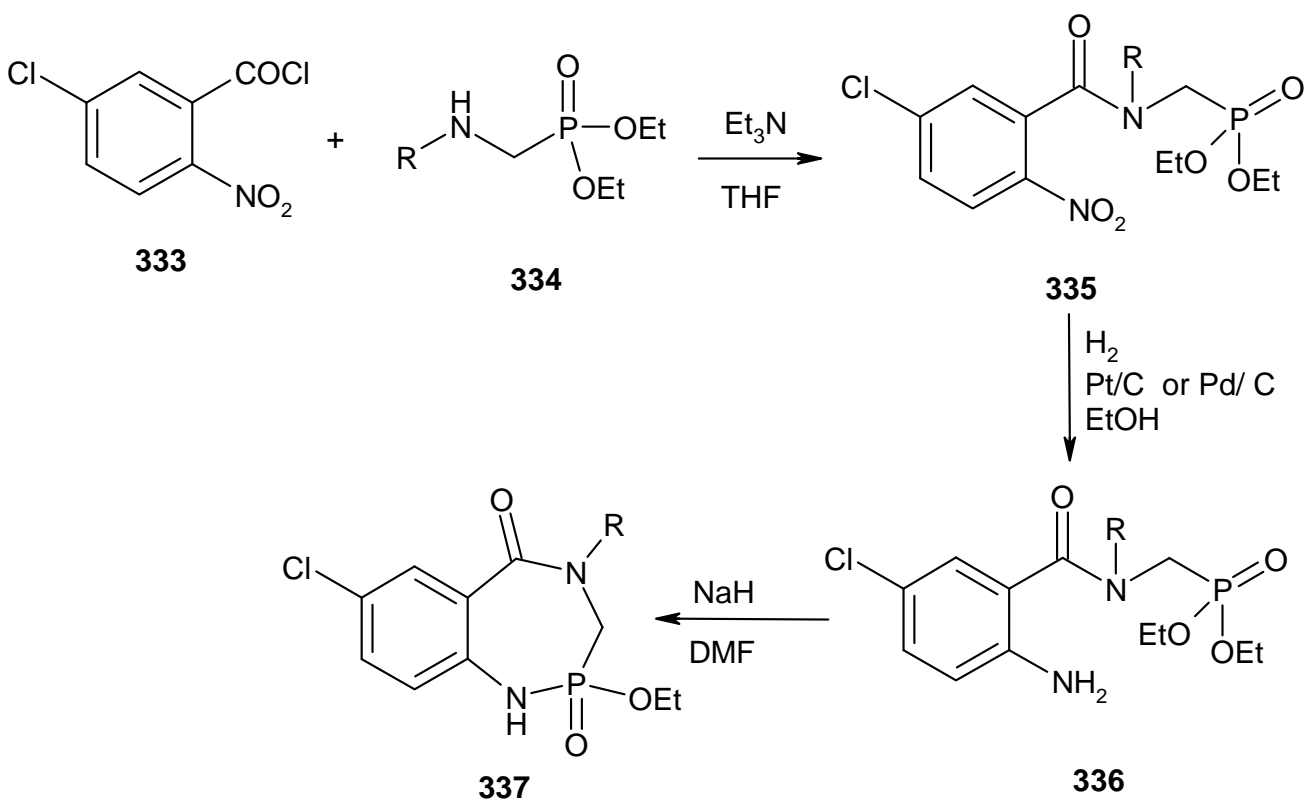

\section{Scheme 105}

$\mathrm{R}=\mathrm{Me}(68 \%), \mathrm{Bu}(57 \%), \mathrm{t}-\mathrm{Bu}(71 \%)$ 


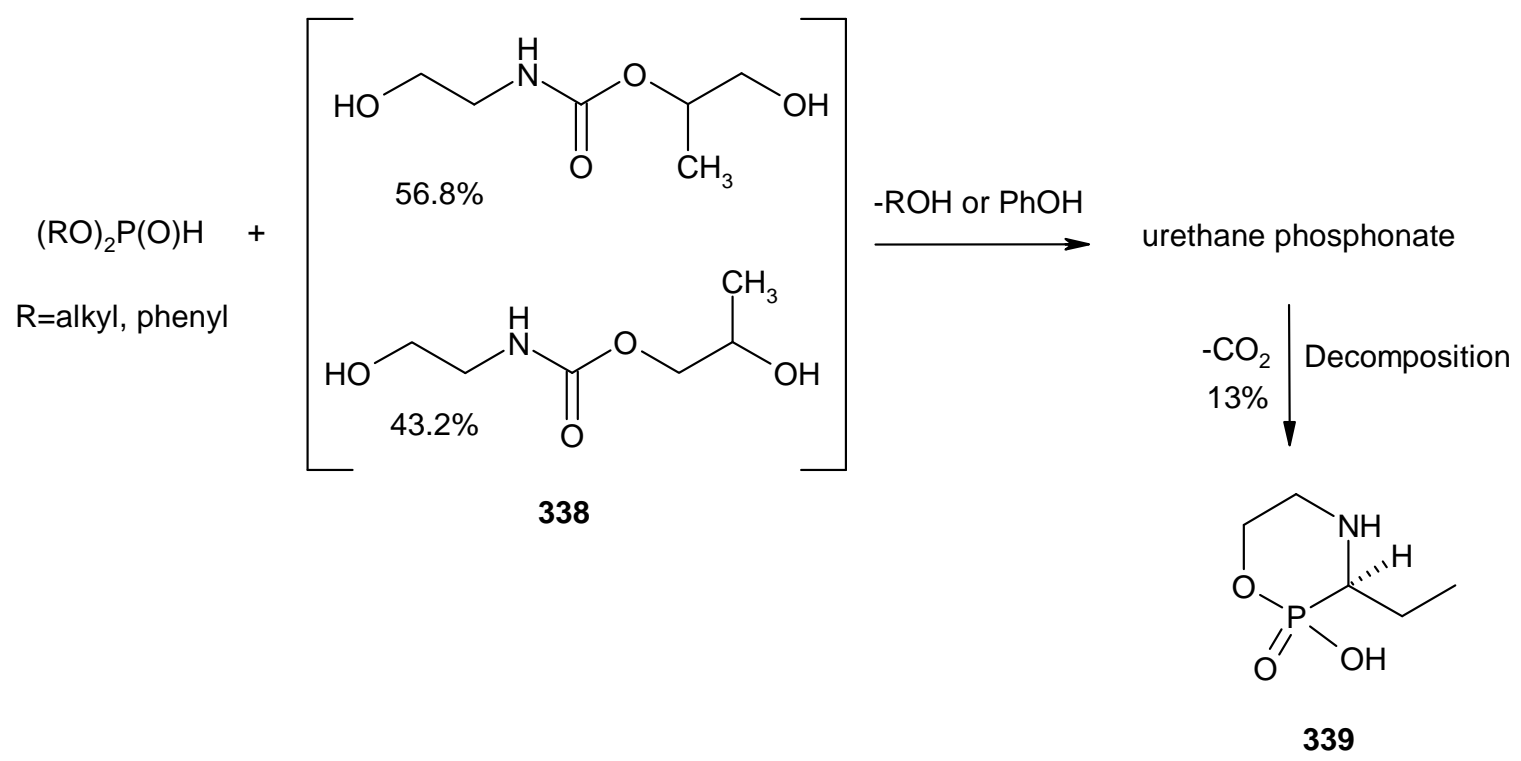

Scheme 106

\section{Conclusions}

This review summarizes most synthetic methods giving rise to cyclic $\alpha$-aminophosphonates. It focuses on the synthesis of cyclic $\alpha$-aminophosphonic acids and their esters which contain at least two atoms. i.e. $\mathrm{C}-\mathrm{P}, \mathrm{C}-\mathrm{N}$ or $\mathrm{P}-\mathrm{C}-\mathrm{N}$, of the $\mathrm{P}-\mathrm{C}-\mathrm{N}$ system, in the heterocyclic system. The review is built up according to the three linkage types and starting with the smallest rings of each type.

\section{References}

1. Noyori, R. Asymmetric Catalysis in Organic Synthesis; John Wiley \& Sons: New York, 1994.

2. Kagan, H. B.; Morrison, J. D. Asymmetric Synthesis; Ed.; Academic Press: Orlando, FL, 1985; Vol. 5, p 1 .

3. Kagan, H. B., Comprehensive Organometallic Chemistry; G. Wilkinson, Ed.; Pergamon Press: Oxford, 1982; Vol. 8, p 463.

4. Morrison, J. D.; Mosher, H. S. Asymmetric Organic Reactions; Prentice-Hall: Englewood Cliffs, NJ, revised ed. (1976), ACS Books, Washington, DC.

5. Kafarski, P.; Lejczak, B. Curr. Med. Chem.-Anti-Cancer Agents 2001, 1, 301. http://dx.doi.org/10.2174/1568011013354543

PMid:12678760 
6. Kafarski, P.; Lejczak, B. Phosphorus, Sulfur Silicon Relat. Elem. 1991, 63, 193. http://dx.doi.org/10.1080/10426509108029443

7. Hilderbrand, R. L. The Role of Phosphonates in Living Systems; CRC Press: Boca Raton, FL, 1983.

8. Engel, R. Synthesis of Carbon-Phosphorus Bond; CRC Press: Boca Raton, FL, 1988.

9. Allen, J. G.; Arthenton, F. R.; Hall, M. J.; Hassall, C. H.; Holmes, S. W.; Lambert, R. W.; Nisbet, L. J.; Ringrose, P. S. Nature 1978, 272, 56.

http://dx.doi.org/10.1038/272056a0

PMid:628432

10. Smith, W. W.; P. A. Bartlett, J. Am. Chem. Soc. 1998, 120, 4622. http://dx.doi.org/10.1021/ja973713z

11. Allen, M. C.; Fuhrer, W.; Tuck, B.; Wade, R.; J. M. Wood, J. Med. Chem. 1989, 32, 1652. http://dx.doi.org/10.1021/jm00127a041

PMid:2661820

12. Hirschmann, R.; Smith, A. B.; Taylor, C. M.; Benkovic, P. A.; Taylor, S. D.; Yager, K. M.; Sprengler, P. A.; Benkovic, S. J. Science 1994, 265, 234.

http://dx.doi.org/10.1126/science.8023141

PMid:8023141

13. Alonso, E.; Solis, A.; Del Pozo, C. Synlett 2000, 698.

14. Kukhar, V. P.; Hudson, H. R. Aminophosphonic and Aminophosphinic Acids: Chemistry and Biological Activity; Ed.; Wiley: New York, 2000.

15. Bhagat, S.; Chakraborti, A. J. Org. Chem. 2007, 72, 1263.

http://dx.doi.org/10.1021/jo062140i

PMid:17253748

16. Palacios, F.; Vicario, J.; Maliszewska, A.; Aparicio, D. J. Org. Chem. 2007, 72, 2682.

http://dx.doi.org/10.1021/jo062609+

PMid:17328577

17. Chandrasekhar, S.; Prakhash, S.; Jagadeshwar, V.; Narsihmulu, C. Tetrahedron Lett. 2001, 42,5561 .

http://dx.doi.org/10.1016/S0040-4039(01)01053-X

18. Manabe, K.; Kobayashi, S. Chem. Commun. 2000, 669.

http://dx.doi.org/10.1039/b000319k

19. Uziel, J.; Genet, J. P. Russ. J. Org. Chem. 1997, 33, 1605.

20. Gancarz, R.; Wieczorek, J. Synthesis 1978, 625.

21. Seyfert, D.; Marmor, R.; Hilbert, P. J. Org. Chem. 1971, 36, 1379. http://dx.doi.org/10.1021/jo00809a014

22. Barycki, J.; Mastalerz, P.; Soroka, M. Tetrahedron Lett. 1970, 3, 3147. http://dx.doi.org/10.1016/S0040-4039(00)99713-2

23. Pudovik, A. N. Doklady Akad. Nauk SSSR, 1952, 83, 865; Chem. Abstr. 1953, 47, 4300. 
24. Kabachnik, M. I.; Medved, T. Ya. Dokl. Akad. Nauk SSSR 1952, 83, 689; Chem. Abstr. 1953, 47, 2724.

25. Kabachnik, M. I.; Medved, T. Ya. Izv. Akad. Nauk SSSR, Ser. Chim. 1953, 1126; idem, ibid. 1954, 1024.

26. Fields, E. J. Am. Chem. Soc. 1952, 74, 1528. http://dx.doi.org/10.1021/ja01126a054

27. Cherkasov, R. A.; Galkin, V. I. Russ. Chem. Rev. 1998, 67, 857; Chem. Abstr. 1953, 47, $2724 b$.

28. LaPointe, A. M. J. Comb. Chem. 1999, 1, 101. http://dx.doi.org/10.1021/cc980013x

29. Huang, J.; Chen, R. Heteroatom Chem. 2000, 11, 480. http://dx.doi.org/10.1002/1098-1071(2000)11:7<480::AID-HC6>3.0.CO;2-J

30. Failla, S.; Finocchiaro, P.; Consiglio, G. A. Heteroatom Chem. 2000, 11, 493. http://dx.doi.org/10.1002/1098-1071(2000)11:7<493::AID-HC7>3.0.CO;2-A

31. Zefirov, N. S.; Matveeva, E. D. Arkivoc 2008, $i, 1$. http://dx.doi.org/10.3998/ark.5550190.0009.101

32. Moore, J. D.; Sprott, K. T.; Hanson, P. R. J. Org. Chem. 2002, 67, 8123. http://dx.doi.org/10.1021/jo0262208

33. Ali, T. E. Phosphorus, Sulfur Silicon Relat. Elem. 2010, 185, 88. http://dx.doi.org/10.1080/10426500802713309

34. Fineta, J. P.; Frejaville, C.; Lauricella, R.; Le Moigne, F.; Stipa, P.; Tordo, P. Phosphorus, Sulfur Silicon Relat. Elem. 1993, 81, 17.

http://dx.doi.org/10.1080/10426509308034370

35. Chalier, F.; Tordo, P. J. Chem. Soc., Perkin Trans. 2 2002, 2110 http://dx.doi.org/10.1039/b206909c

36. Issleib, K.; Dopfer, K. P.; Balsuweit, A. Z. Chem. 1982, 215.

37. Issleib, K.; Dopfer, K. P.; Balszuweit, A. Phosphorus, Sulfur Silicon Relat. Elem. 1987, 30, 633.

http://dx.doi.org/10.1080/03086648708079144

38. Clement, J. L.; Finet, J. P.; Frejaville, C.; Tordo, P. Org. Biomol. Chem. 2003, 1, 1591. http://dx.doi.org/10.1039/b300870c

PMid:12926292

39. Haak, E.; Bytschkov, I.; Doye, S. Eur. J. Org. Chem. 2002, 457. http://dx.doi.org/10.1002/1099-0690(20022)2002:3<457::AID-EJOC457>3.0.CO;2-B

40. Odinets, I. L.; Artyushin, I.; Konstantin, A. L.; Nikolay, E. S.; Valentin, G. N.; Roschenthaler, G. J. Fluorine Chem. 2009, 130, 662. http://dx.doi.org/10.1016/j.jfluchem.2009.05.002

41. Schlemminger, I.; Saida, Y.; Groger, H.; Maison, W.; Durot, N.; Sasai, H.; Shibasaki, M.; Martens, J. J. Org. Chem. 2000, 65, 4818. http://dx.doi.org/10.1016/j.jfluchem.2009.05.002 
42. Schlemminger, I.; Willecke, A.; Maison, W.; Koch, R.; Lutzen, A.; Martens, J. J. Chem. Soc. Perkin Trans. 1 2001, 2804.

43. Hoppe, I.; Schollkopf, U.; Nieger, M.; Egert, E. Angew. Chem., Int. Ed. Engl. 1985, 24, 1067.

http://dx.doi.org/10.1002/anie.198510671

44. Redmore, D. Chem. Rev. 1971, 71, 315.

http://dx.doi.org/10.1021/cr60271a003

45. Louaisil, N.; Rabasso, N.; Fadel, A. Tetrahedron. 2009, 65, 8587.

http://dx.doi.org/10.1016/j.tet.2009.07.040

46. Gröger, H.; Manikowski, J.; Martens, J. Phosphorus, Sulfur Silicon Relat. Elem. 1996, 116, 123.

http://dx.doi.org/10.1080/10426509608040475

47. Sonar, S. S.; Sadaphal, S. A.; Shitole, N. V.; Jogdand, N. R.; Shingate, B. B.; Shingare, M. S. Bull. Korean Chem. Soc. 2009, 30, 1711. http://dx.doi.org/10.5012/bkcs.2009.30.8.1711

48. Sonar, S. S.; Sadaphal, S. A.; Labade, V. B.; Shingate, B. B.; Shingare, M. S. Phosphorus, Sulfur Silicon Relat. Elem. 2010, 185, 65.

http://dx.doi.org/10.1080/10426500802713259

49. Rohovec, J.; Vojtisek, P.; Lukes, I. Phosphorus, Sulfur Silicon Relat. Elem. 1999, 148, 79. http://dx.doi.org/10.1080/10426509908037002

50. Chevrier, C.; Le Nouen, D.; Defoin, A.; Tarnus, C. Eur. J. Org. Chem. 2006, 2384. http://dx.doi.org/10.1002/ejoc.200500990

51. Shatzmiller, S.; Dolitzky, B. Z.; Meirovich, R.; Neidlein, R.; Weik, C. Liebigs Ann. Chem. 1991, 161.

http://dx.doi.org/10.1002/jlac.199119910129

52. Przychodzen, W.; Konitz, A.; Wojnowski, W.; Rachon, J. Phosphorus, Sulfur Silicon Relat. Elem.. 1998, 134/135, 211.

53. Shono, T.; Matsumura, Y.; Uchida, H.; Nakatani, F. Bull. Chem. Soc. Jpn. 1988, 61, 3029. http://dx.doi.org/10.1246/bcsj.61.3029

54. Clauss, K.; Grimm, D.; Prossel, G. Liebigs Ann. Chem. 1974, 539

55. Campbell, M. M.; Carruthers, N. I. J. Chem. Soc. Chem. Commun. 1980, 730. http://dx.doi.org/10.1039/c39800000730

56. Campbell, M. M.; Carruthers, N. I.; Mickel, S. J. Tetrahedron 1982, 38, 2513. http://dx.doi.org/10.1016/0040-4020(82)85087-4

57. Kita, Y.; Shibata, N.; Yoshida, N.; Tohjo, T. Chem. Pharm. Bull. 1992, 40, 1733 http://dx.doi.org/10.1248/cpb.40.1733

58. Amedjkouh, M.; Westerlund, K.; Tetrahedron Lett. 2004, 45, 5175. http://dx.doi.org/10.1016/j.tetlet.2004.04.009

59. Diner, P.; Amedjkouh, M. Org. Biomol. Chem. 2006, 4, 2091. 
http://dx.doi.org/10.1039/b605091c

PMid:16729122

60. Katritzky, A. R.; Cui, X. L.; Yang, B.; Steel, P. J. J. Org. Chem. 1999, 64, 1979 http://dx.doi.org/10.1021/jo9821426

61. Chen, W.; Gang, Z.; Ding, K. Chinese J. Chem. 2009, 27, 163. http://dx.doi.org/10.1002/cjoc.200990011

62. Tao, Q.; Tang, G.; Lin, K.; Zhao, Y. F. Chirality 2008, 20, 833. http://dx.doi.org/10.1002/chir.20552

PMid:18381740

63. Katritzky, A. R.; Mehta, S.; He, H. Y.; Cui, X. J. Org. Chem. 2000, 65, 4364. http://dx.doi.org/10.1021/jo000219w

64. Bausanne, I.; Chiaroni, A.; Royer, J. Tetrahedron Asymm. 2001, 12, 1219. http://dx.doi.org/10.1016/S0957-4166(01)00195-1

65. Kaname, M.; Mashige, H.; Yoshifuji, S. Chem. Pharm. Bull. 2001, 49, 531. http://dx.doi.org/10.1248/cpb.49.531

66. Boto, A.; Gallardo, J. A.; Hernandez, R.; Saavedra, C. J. Tetrahedron Lett. 2005, 46, 7807. http://dx.doi.org/10.1016/j.tetlet.2005.09.019

67. Maury, C.; Wang, Q.; Gharbaoui, T.; Chiadmi, M.; Tomas, A.; Royer, J.; Husson, H. P. Tetrahedron 1997, 53, 3627. http://dx.doi.org/10.1016/S0040-4020(97)00086-0

68. Katritzky, A. R.; Qiu, G.; Yang, B.; Steel, P. J. J. Org. Chem. 1998, 63, 6699. http://dx.doi.org/10.1021/jo980719d

69. Shono, T.; Matsumura, Y.; Tsubata, K. Tetrahedron Lett. 1981, 22, 3249. http://dx.doi.org/10.1016/S0040-4039(01)81876-1

70. Frejaville, C.; Karoui, H.; Tuccio, B.; Le Moigne, F.; Culcasi, M.; Pietri, S.; Lauricella, R.; Tordo, P. J. Med. Chem. 1995, 38, 258. http://dx.doi.org/10.1021/jm00002a007

71. Frejaville, C.; Karoui, H.; Tuccio, B.; Le Moigne, F.; Culcasi, M.; Pietri, S.; Lauricella, R.; Tordo, P. J. Chem. Soc. Chem Commun. 1994, 1793. http://dx.doi.org/10.1039/c39940001793

72. Van Assche, I.; Soroka, M.; Haemers, A.; Hooper, M.; Blanot, D.; Van Heijenoort, J. Eur. J. Med. Chem. 1991, 26, 505. http://dx.doi.org/10.1016/0223-5234(91)90146-E

73. Davis, F. A.; Wu, Y. Z.; Yan, H.; Kavirayani, R. P.; McCoull, W. Org. Lett. 2002, 4, 655. http://dx.doi.org/10.1021/o1017289p

PMid:11843615

74. Azab, A.; Quntar, A.; Antebi, T.; Srebnika, M. Heterocycles 2010, 82, 417. http://dx.doi.org/10.3987/COM-10-S(E)12

75. Kaname, M.; Arakawa, Y.; Yoshifuji, S. Tetrahedron Lett. 2001, 42, 2713. http://dx.doi.org/10.1016/S0040-4039(01)00283-0 
76. Stevens, C.; Gallant, M.; De Kimpe, N. Tetrahedron Lett. 1999, 40, 3457.

http://dx.doi.org/10.1016/S0040-4039(99)00422-0

77. Davis, F. A.; McCoull, W. Tetrahedron Lett. 1999, 40, 249.

http://dx.doi.org/10.1016/S0040-4039(98)02331-4

78. Dehnel, A.; Lavielle, G. Tetrahedron Lett. 1980, 21, 1315.

http://dx.doi.org/10.1016/S0040-4039(00)74564-3

79. Rabiller, C.; Dehnel, A.; Lavielle, G. Can. J. Chem. 1982, 60, 926.

http://dx.doi.org/10.1139/v82-139

80. Dehnel, A.; Kanabus-Kaminska, J. M.; Lavielle, G. Can. J. Chem. 1988, 66, 310.

http://dx.doi.org/10.1139/v88-054

81. Dondas, H. A.; Durust, Y.; Grigg, R.; Slater, M. J.; Sarker, M. A. Tetrahedron 2005, 61, 10667.

http://dx.doi.org/10.1016/j.tet.2005.08.079

82. Hamilton, R.; Walker, B.; Walker, B. J. Bioorg. Med. Chem. Lett. 1998, 8, 1655.

http://dx.doi.org/10.1016/S0960-894X(98)00272-8

83. Jacquier, R.; Ouazzani, F.; Roumestant, M. L.; Viallefont, P. Phosphorus, Sulfur Silicon Relat. Elem. 1988, 36, 73.

http://dx.doi.org/10.1080/03086648808079000

84. Groth, U.; Richter, L.; Schollkopf, U. Tetrahedron 1992, 48, 117.

http://dx.doi.org/10.1016/S0040-4020(01)80584-6

85. Groth, U.; Richter, L.; Schollkopf, U. Liebigs Ann. Chem. 1992, 903.

http://dx.doi.org/10.1002/jlac.1992199201150

86. Palacios, F.; Ochoa de Retana, A. M.; Pagolday, J. Eur. J. Org. Chem. 2003, 913.

http://dx.doi.org/10.1002/ejoc.200390139

87. Rassukana, Y. V.; Kolotylo, M. V.; Sinitsa, O. A.; Pirozhenko, V. V.; Onys'ko, P. P. Synthesis 2007, 2627.

88. Palacios, F.; Ochoa de Retana, A. N.; Gil, J. I. Tetrahedron Lett. 2000, 41, 5363. http://dx.doi.org/10.1016/S0040-4039(00)00843-1

89. Palacios, F.; Aparicio, D.; Ochoa de Retana, A. M.; De los Santos, J. M.; Gil, J. I.; Lopez de Munain, R. Tetrahedron Asymm. 2003, 14, 689.

http://dx.doi.org/10.1016/S0957-4166(03)00089-2

90. Subotkowski, W.; Tyka, R.; Mastalerz, P. Pol. J. Chem. 1983, 57, 1389.

91. Dolence, E. K.; Roylance, J. B. Tetrahedron Asymm. 2004, 15, 3307. http://dx.doi.org/10.1016/j.tetasy.2004.08.034

92. Guseinov, F. I.; Burangulova, R. N.; Klimentova, G. U. Phosphorus, Sulfur Silicon Relat. Elem. 1999, 147, 479.

http://dx.doi.org/10.1080/10426509908053719

93. Shiozaki, M.; Masuko, H. Heterocycles 1984, 22, 1727.

http://dx.doi.org/10.3987/R-1984-08-1727

94. Shiozaki, M.; Masuko,H. Bull. Chem. Soc. Jpn. 1987, 60, 645. 
http://dx.doi.org/10.1246/bcsj.60.645

95. Moczygemba, R.; Frei, C. R.; Burgess, D. S. Clinic. Therap. 2004, 26, 1800.

http://dx.doi.org/10.1016/j.clinthera.2004.11.009

PMid:15639692

96. Stevens, C. V.; Vekemans, W.; Moonen, K.; Rammeloo, T. Tetrahedron Lett. 2003, 44, 1619.

http://dx.doi.org/10.1016/S0040-4039(03)00005-4

97. Speybroeck, V. V.; Moonen, K.; Hamelsoet, K.; Stevens, C. V.; Waroquier, M. J. Am. Chem. Soc. 2006, 128, 8468.

http://dx.doi.org/10.1021/ja0584119

PMid:16802812

98. Agami, C.; Couty, F.; Rabasso, N. Tetrahedron Lett. 2002, 43, 4633. http://dx.doi.org/10.1016/S0040-4039(02)00868-7

99. Subotkowski, W.; Tyka, R.; Mastalerz, P. Pol. J. Chem. 1980, 54, 503.

100. Kachkovski, G. O.; Kolodiazhnyi, O. I. Tetrahedron 2007, 63, 12576.

http://dx.doi.org/10.1016/j.tet.2007.10.022

101. Dieltiens, N.; Moonen, K.; Stevens, C. V. Chem. Eur. J. 2007, 13, 203.

http://dx.doi.org/10.1002/chem.200600789

PMid:17013964

102. Amedjkouh, M.; Faure, R.; Hatem, J.; Tordo, P.; Grimaldi, J. Phosphorus, Sulfur Silicon Relat. Elem. 1997, 126, 53. http://dx.doi.org/10.1080/10426509708043545

103. Amedjkouh, M.; Grimaldi, J. Phosphorus, Sulfur Silicon Relat. Elem. 2002, 177, 391. http://dx.doi.org/10.1080/10426500210239

104. Rammeloo, T.; Stevens, C. V.; Soenen, B. Eur. J. Org. Chem. 2004, 1271. http://dx.doi.org/10.1002/ejoc.200300654

105. Le Moigne, F.; Mercier, A.; Tordo, P. Tetrahedron Lett. 1991, 32, 3841. http://dx.doi.org/10.1016/S0040-4039(00)79391-9

106. Roubaud, V.; Le Moigne, F.; Mercier, A.; Tordo, P. Phosphorus, Sulfur Silicon Relat. Elem. 1994, 86, 39.

http://dx.doi.org/10.1080/10426509408018386

107. Le Moigne, F.; Tordo, P. J. Org. Chem. 1994, 59, 3365.

http://dx.doi.org/10.1021/jo00091a024

108. Yamaguchi, M.; Tsukamoto, Y.; Hayashi, A.; Minami, T. Tetrahedron Lett. 1990, 31, 2423. http://dx.doi.org/10.1016/S0040-4039(00)97378-7

109. Davis, F. A.; Lee, S. H.; Xu, H. J. Org. Chem. 2004, 69, 3774. http://dx.doi.org/10.1021/jo040127x

PMid:15153008

110. Vanderhoydonck, B.; Stevens, C. V. Tetrahedron. 2007, 63, 7679. 
http://dx.doi.org/10.1016/j.tet.2007.05.023

111. Dolence, E. K.; Mayer, G.; Kelly, B. D. Tetrahedron Asymm. 2005, 16, 1583.

http://dx.doi.org/10.1016/j.tetasy.2005.02.014

112. Godin, G.; Compain, P.; G.; Masson, O. R. Martin, J. Org. Chem. 2002, 67, 6960.

http://dx.doi.org/10.1021/jo0203903

PMid:12353989

113. Osipov, S. N.; Artyushin, O. I.; Kolomiets, A. F.; Bruneau, C.; Dixneuf, P. H. Synlett 2000, 7, 1031.

114. Osipov, S. N.; Artyushin, O. I.; Kolomiets, A. F.; Bruneau, C.; Picquet M., Dixneuf, P. H. Eur. J. Org. Chem. 2001, 3891. http://dx.doi.org/10.1002/1099-0690(200110)2001:20<3891::AID-EJOC3891>3.0.CO;2-R

115. Ding, Q.; Ye, Y.; Fan, R.; Wu, J. J. Org. Chem. 2007, 72, 5439.

http://dx.doi.org/10.1021/jo070716d

PMid:17559281

116. Christensen, B. G.; Beattie, T. R. Ger. Offen. 2011092, 1970; Chem. Abstr. 1971, 74, 42491.

117. Zygmunt, J. Tetrahedron 1985, 41, 4979.

http://dx.doi.org/10.1016/S0040-4020(01)96741-9

118. Thomas, A. A.; Sharpless, K. B. J. Org. Chem. 1999, 64, 8379.

http://dx.doi.org/10.1021/jo990060r

119. Davis, F. A.; McCoull, W.; Titus, D. D. Org. Lett. 1999, 1, 1053.

http://dx.doi.org/10.1021/o1990855k

PMid:10825956

120. Davis, F. A.; Wu, Y.; Yan, H.; McCoull, W.; Prasad, K. R. J. Org. Chem. 2003, 68, 2410. http://dx.doi.org/10.1021/jo020707z

PMid:12636410

121. Otmar, M.; Polakova, L.; Masojidkova, M.; Holy, A. Collect. Czech. Chem. Commun. 2001, 66, 507. http://dx.doi.org/10.1135/cccc20010507

122. Davis, F. A.; Wu, Y.; Xu, Zhang, H. Org. Lett. 2004, 6, 4523.

http://dx.doi.org/10.1021/o1048157+

PMid:15548066

123. Davis, F. A.; Wu, Y. Org. Lett. 2004, 6, 1269.

http://dx.doi.org/10.1021/o1049795v

PMid:15070314

124. Mikroyannidis, J. A.; Tsolis, A. K. J. Heterocycl. Chem. 1982, 19, 1179. http://dx.doi.org/10.1002/jhet.5570190538

125. Mikroyannidis, J. A.; Tsolis, A. K. Appl. Spectrosc. 1982, 36, 446.

http://dx.doi.org/10.1366/0003702824639547

126. Blazewska, K.; Sikora, D.; Gajda, T. Tetrahedron Lett. 2003, 44, 4747. 
http://dx.doi.org/10.1016/S0040-4039(03)01048-7

127. Blazewska, K.; Gajda, T. Tetrahedron 2004, 60, 11701.

http://dx.doi.org/10.1016/j.tet.2004.10.004

128. Blaszczyk, R.; Gajda, T.; Wojciechowski, J.; Wolf, W. M. Tetrahedron. Lett. 2007, 48, 5859.

http://dx.doi.org/10.1016/j.tetlet.2007.06.063

129. Palacios, F.; Ochoa de Retana, A. M.; Alonso, J. M. J. Org. Chem. 2005, 70, 8895.

http://dx.doi.org/10.1021/jo051404i

PMid:16238324

130. Olive, G. Jacques, A. Phosphorus, Sulfur Silicon Relat. Elem. 2003, 178, 33. http://dx.doi.org/10.1080/10426500307821

131. Belyaev, A.; Borloo, M.; Augustyns, K. J.; Lambeir, A. M. V.; De Meester, I.; Scharpe, S. L.; Blaton, N.; Peeters, O. M.; De Ranter, D.; Haemers, A. Tetrahedron Lett. 1995, 36, 3755 .

http://dx.doi.org/10.1016/0040-4039(95)00586-2

132. Belyaev, A.; Zhang, X.; Augustyns, K.; Lambeir, A.; De Meester, I.; Vedernikova, I.; Scharpe, S. L.; Haemers, A. J. Med. Chem. 1999, 42, 1041.

http://dx.doi.org/10.1021/jm981033g

PMid:10090787

133. Yuan, C. Y.; Huang, W. S. Chin. Chem. Lett. 1994, 5, 565; Chem. Abstr. 1994, 121, 1185.

134. Piotrowska, D. G. Tetrahedron Lett. 2006, 47, 5363. http://dx.doi.org/10.1016/j.tetlet.2006.05.104

135. Dimukhametov, M. N.; Bajandina, E. V.; Davydova, E. Y.; Litvinov, I. A.; Gubaidullin, A. T.; Dobrynin, A. B.; Zyablikova, T. A.; Alfonsov, V. A. Heteroatom Chem. 2003, 14, 56. http://dx.doi.org/10.1002/hc.10054

136. Dimukhametov, M. N.; Davydova, E. Y.; Bayandina, E. V.; Dorhynin, A. B.; Litvinov, I. A.; Alfonsov, V. A. Mendeleev. Commun. 2001, 11, 222. http://dx.doi.org/10.1070/MC2001v011n06ABEH001506

137. Dimukhametov, M. N.; Bajandina, E. V.; Davydova, E. Yu.; Dobrynin, A. B.; Gubaidullin, A. T.; Litvinov, I. A.; Alfonsov, V. A. Mendeleev Commun. 2001, 11, 196. http://dx.doi.org/10.1070/MC2001v011n05ABEH001478

138. Ali, T. E. Eur. J. Med. Chem. 2009, 44, 4539.

http://dx.doi.org/10.1016/j.ejmech.2009.06.022

PMid:19615792

139. Abdel-Aziz, S. A.; Ali, T. E.; El-Mahdy, K. M.; Abdel-Karim, S. M. Eur. J. Chem. 2011, 2, 25 .

http://dx.doi.org/10.5155/eurjchem.2.1.25-35.208

140. Ali, T. E. Arkivoc 2008, (ii), 71.

141. Pudovik, A. N.; Konovalova, I. V. Sov. Sci. Revs.(Harwood Academic Publishers). 1984, 6, 226. 
142. Konovalova, I. V.; Gareev, R. D.; Burnaeva, L. A.; Cherkina, M. V.; Khayarov, A. I.; Pudovik,A. N. Zh. Obshch. Khim. 1980, 50, 1446.

143. Vuano, B. M.; Acebal, S. G.; Sala, O.; Brieux, O.; Pieroni, O. I. J. Mol. Struct. 2004, 690, 77.

http://dx.doi.org/10.1016/j.molstruc.2003.11.034

144. Wang, B.; Miao, Z.; Huang, Y.; Chen, R. Heteroatom Chem. 2007, 18, 65. http://dx.doi.org/10.1002/hc.20258

145. Cosma, E. F.; Ilia, G.; Cosma, G. F.; Vlascici, D.; Bizerea, O.; Istratuca, G. Phosphorus, Sulfur Silicon Relat. Elem. 2004, 179, 1673. http://dx.doi.org/10.1080/10426500490466256

146. Cosma, E. F.; Laichici, M.; Cosma, G. F.; Vlascici, D. J. Serb. Chem. Soc. 2006, 71, 1031. http://dx.doi.org/10.2298/JSC0610031F

147. Cosma, E. F.; Magda, A. Chem. Bull. Politehnica Univ. (Timişoara) 2006, 51, 20.

148. Wang, B.; Miao, Z. W.; Haung, Y.; Chen, R. Y. Heterocycles 2006, 68, 2123. http://dx.doi.org/10.3987/COM-06-10838

149. Wang, B.; Miao, Z. W.; Chen, R. Y. Phosphorus, Sulfur Silicon Relat. Elem. 2009, 184, 2739. http://dx.doi.org/10.1080/10426500903095564

150. Octaviano, J. Z.; Martinez, A. H.; Guevara, A. O.; Elizalde, I. L.; Hopfl, H. Heteroatom Chem. 2006, 17, 75 .

http://dx.doi.org/10.1002/hc.20178

151. Aime, S.; Cavallotti, C.; Gianolio, E.; Giovenzana, G. B.; Palmisano, G.; Sisti, M. Tetrahedron 2002, 43, 8387. http://dx.doi.org/10.1016/S0040-4039(02)01950-0

152. Fadel, A.; Tesson, N. Tetrahedron Asymm. 2000, 11, 2023. http://dx.doi.org/10.1016/S0957-4166(00)00134-8

153. Levkovskii, A. V.; Akinenko, A. Yu.; Pushin, A. N.; Sokolov, V. B. Phosphorus, Sulfur Silicon Relat. Elem. 1999, 144-146, 827. http://dx.doi.org/10.1080/10426509908546367

154. Cherkasov, R.; Khailova, N.; Schaimardanova, A.; Saakian, G.; Pudovik, M.; Pudovik, A. Phosphorus, Sulfur Silicon Relat. Elem. 2002, 177, 2127. http://dx.doi.org/10.1080/10426500213368

155. Khailova, N. A.; Shaimardanova, A. A.; Saakyan, G. M.; Zyablikova, T. A.; Azancheev, N. M.; Krivolapov, D. B.; Gubaidullin, A. T.; Litvinov, I. A.; Musin,R. Z.; Chmutova, G. A.; Pudovik, M. A.; Pudovik, A. N. Russ. J. Gen. Chem. 2003, 73, 1213. http://dx.doi.org/10.1023/B:RUGC.0000007644.95638.fc

156. Pudovik, M. A.; Khailova, N. A.; Shaimardanova, A. A. Alfonsov,; V. A.; Kataeva, O. N. Phosphorus, Sulfur Silicon Relat. Elem.2009, 184, 1355. http://dx.doi.org/10.1080/10426500902930159

157. Pudovik, M. A.; Kibardina, L. K. Russ. J. Gen. Chem. 2008, 78, 155. 


\section{http://dx.doi.org/10.1134/S1070363208010301}

158. Linzaga, I.; Escalante, J.; Munoz, M.; Juaristi, E. Tetrahedron, 2002, 58, 8973. http://dx.doi.org/10.1016/S0040-4020(02)01152-3

159. Maury, C.; Gharbaoui, T.; Royer, J.; Husson, H. P. J. Org. Chem. 1996, 61, 3687. http://dx.doi.org/10.1021/jo960020c

160. Karp, G. M. J. Org. Chem. 1999, 64, 8156. http://dx.doi.org/10.1021/jo9908400

161. Troev, K.; Koseva, N.; Hagele, G. Heteroatom. Chem. 2008, 19, 119. http://dx.doi.org/10.1002/hc.20404

162. Troev, K.; Cremer, S.; Hagele, G. Heteroatom. Chem. 1999, 10, 627. http://dx.doi.org/10.1002/(SICI)1098-1071(1999)10:7<627::AID-HC17>3.0.CO;2-C

163. Naydenova, E.; Troev, K.; Topashka-Ancheva, M.; Hagele, G.; Ivanov, I.; Kril, A. Amino acids 2007, 33, 695.

http://dx.doi.org/10.1007/s00726-006-0459-y

PMid:17103117

\section{Author's Biography}

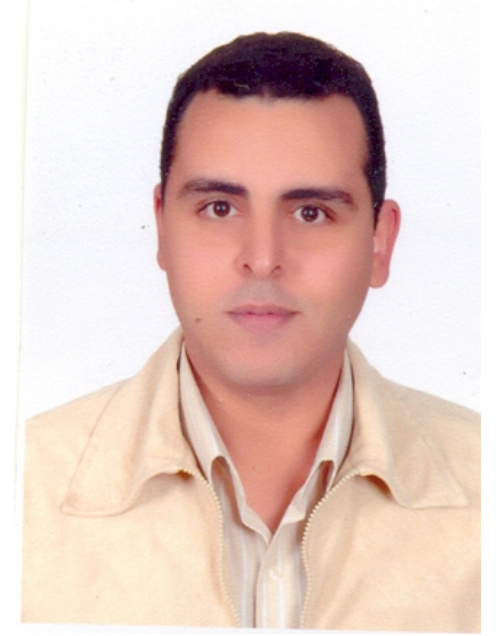

Tarik El-Sayed Ali was born in Cairo, Egypt, in 1975. He is presently assistant professor of organic chemistry, Department of Chemistry, Faculty of Education, Ain Shams University, Cairo, Egypt. He graduated with B.Sc. (Physics and Chemistry) from Ain Shams University in 1997. He received his M.Sc. and Ph.D. degrees in 2001 and 2005, respectively, in heterocyclic chemistry from Ain Shams University. Awarded a post doctoral scientific grant for supporting young researchers (2007) from the Ministry of High Education and Scientific Research (Egypt) in organophosphorus laboratory, Institute of Polymers, Bulgarian Academy of Science, Sofia, Bulgaria. His CV was involved in Who's Who in the World in 2011 and 2012. He won the award 
for the best research article in heterocyclic chemistry field at the Egyptian universities and research centers in 2011. He has published more than 35 scientific papers including 9 review articles, all in international journals. His research interests are in synthesis and chemical reactivity of phosphorus compounds contain bioactive heterocyclic systems. 